UNIVERSIDAD NACIONAL DE LA PLATA

FACULTAD DE HUMANIDADES Y CIENCIAS DE LA EDUCACIÓN

SECRETARÍA DE POSGRADO

\title{
El uso del cuerpo femenino en los medios de comunicación masiva.
}

Cuerpos femeninos en programas y publicidades de la televisión argentina actual. Estereotipos, roles y criterios de belleza.

\author{
Profesora Marisa Gugliotta
}

Tesis para optar por el grado de Magíster en Educación Corporal Directora Magister Daniela Yutzis, Universidad Nacional de La Plata

La Plata, 1 de julio de 2013 
"Yo creo en cruzar la línea tantas veces como sea necesario para construir un puente que todos podamos caminar a través."

Del La Grace Volcano 
A la Universidad de La Plata en su Departamento de Posgrados Educación Física por aceptarme en esta Maestría.

A mi Directora de Tesis, Daniela Yutzis porque sin su insistencia, confianza y extrema paciencia tal vez no hubiera llegado al final.

A los profesores de cada uno de los seminarios por iluminar el camino con asombrosa inteligencia.

A cada uno de los autores presentes en la bibliografía por ser decisivos en la generación de nuevos pensamientos.

A Sandra Gugliotta mi entusiasta hermana.

A Angeles Martinez por su asesoramiento, su enseñanza y su amistad

A Maria Jose Barros por sus correcciones.

A Tina Aboitiz por esperarme.

A mis compañeros de la cohorte 2005 por el clima cálido y sincero con que recorrimos cada clase.

A mis alumnas del secundario de Calafate.

A mis alumnos de La Plata

A mi familia, revuelta, extensa y revolucionaria que me vio todos estos años frente a la computadora.

A Nicolas y Julia, por sus femeninos y masculinos.

A Luis Calleja por acercarme sus ideas, su confianza, por traerme libros y lo más importante: por regalarme la computadora. 
Introducción, 4 pág.

I. El cuerpo femenino

- El concepto de cuerpo, 11 pág.

- El cuerpo que vemos en televisión, 17pag.

- La grilla de observación, 17pag

- Los cuerpos de cada día, 25pag

II. El Cuerpo Femenino en la televisión, 32pag.

- Cuerpos que venden, 47 pag

III. Las Mujeres, 54pag.

- Las formas, 55pag

- La juventud y la seducción, 59pag

- La victimización, 62pag

- La desnudez, 64pag

- Las pasiones, 68pag

IV. La televisión argentina actual, 74 pag.

V. Las tensiones, 80 pag.

Apartado I Las planillas, 84 pag.

Apartado II Los cinco programas observados, 90 pag.

Bibliografía, 101 pag 
“...quedan dos bastiones por conquistar: el de las mentalidades (tanto de hombres como de mujeres) y el de la esfera doméstica. El sistema de denigración y de desvalorización de lo femenino se transmite por medio de la educación, el lenguaje, los usos habituales de la violencia $y$ de las imágenes.” Françoise Héritier

En nuestra vida cotidiana los hombres y las mujeres nos sentimos seguros. Dentro de una trama de rutinas y hábitos nos rodeamos de afectos con quienes discutir y discernir los temas que nos conmueven. Cada quien teje su propia vida. Ama, crece, envejece, siente placer, dolor, indiferencia o rabia. En ese ámbito cada individuo puede adaptar, apaciguar o negar los efectos del mundo social en el que vive. Mundo que impone conductas y reglas con las cuales no siempre se está de acuerdo. Las pulsiones del cuerpo permiten ver como repercuten en cada uno de nosotros las relaciones que tenemos con nuestro mundo social. Estamos afectivamente en el mundo. Somos nuestro estar en el mundo y nuestro cuerpo es la clave. "Nuestras percepciones, nuestras experiencias construyen el mundo que vivimos, somos indiscernibles de nuestro cuerpo que le otorga espesor y sensibilidad a nuestra vida"l.

Este trabajo parte del concepto de "cuerpo moderno"2 de David Le Breton según el cual el cuerpo se convierte en un objeto que el hombre posee, que estudia, que modela según sus deseos. El cuerpo es el límite que lo separa de los demás, que lo distingue de otras personas y del mundo natural, que lo convierte, entonces, en individuo.

Este individuo no puede ser indiferente, vive en un mundo social que día a día le transmite formas de hacer, de pensar, de sentir. Costumbres y creencias que llegan a cada uno a lo largo del tiempo, a veces de generación en generación y otras veces minuto a minuto.

Por elección del tema que nos ocupa solo observaremos los cuerpos femeninos y del mundo social en que vivimos solo consideraremos los medios de comunicación masiva. Entre ellos, la televisión es quien nos convoca por ser el medio mas popular y de facil acceso. A pesar del avance de nuevos dispositivos tecnológicos como teléfonos inteligentes, videos e

\footnotetext{
1 David Le Bretton. Antropologia del cuerpo y modernidad. Ed. Nueva Vision. Argentina. 2002

${ }^{2}$ David Le Bretton. Antropología del cuerpo y modernidad. Ed. Nueva Visión. Argentina. 2002
} 
Internet, la televisión sigue teniendo un efecto convocante. Imposible interactuar con ella como lo hacemos en el facebook o en twiter, o incluso como las versiones on line de los diarios, la televisión donde solo miramos sigue siendo capaz de atraer gente de distintas edades, clases sociales, generos. Reímos, lloramos, juzgamos, jugamos, a través de esa pantalla. A través de esas personas que se presentan en la tv en una insoportable dualidad. Son uno más de nosotros, conocemos sus nombres, su imagen, sus opiniones, reconocemos sus voces como reconocemos las voces de nuestros familiares pero al mismo tiempo son estrellas, ídolos inalcanzables. Ellos tienen nombre y apellido, nosotros somos "la gente". Ellos tienen voz, nosotros mirada. Mayoritariamente ellos tienen (o parecen tener) dinero, mayoritariamente nosotros no. Ellos son vistos, nosotros no. "Ser” según George Berkeley, es "es ser visto" entonces ellos son, nosotros no.

El mundo social actual está impregnado de televisión y en ella podemos encontrar todo lo que la sociedad nos pide o exige. En la televisión podemos encontrar gran parte del mundo que nos rodea. Afirmaciones, negaciones, críticas, historias, mentiras, todo en un desfile continuo que durante todo el día y toda la noche está dispuesto para ser visto.

La televisión es capaz de mostrar la realidad y de crearla. Y lo mas importante es capaz de llegar a hogares donde hay poco acceso a otros medios de información y/o de educación por lo tanto puede llegar a tener el monopolio de un enorme grupo de personas. Un enorme poder.

En la franja horaria de 14 a 16 hs. casi un millón de hogares argentinos están mirando la televisión. Casi 2.700.000 individuos entre 4 y 79 años, hombres y mujeres, ven lo que sucede en 5 canales de aire en la zona de ciudad de Buenos Aires y gran Buenos Aires. ${ }^{3}$

Pero este no es un ensayo sobre la televisión sino un trabajo de investigación de la relación entre la televisión (TV), el cuerpo femenino (CF) y las mujeres (M). Tres territorios donde se cruzan tensiones que unen y desunen a hombres y mujeres. Y en esas tensiones vamos

3 Datos obtenidos a través de http://www.ibope.com.ar/ibope/wp/ y de la colaboración de Gabriela Guerra, a través de mail, como Ejecutiva de Cuentas. Coordinadora de Media Class. Gerencia Comercial de Ibope. *gabriela.guerra@ibope.com.ar 
creando nuestro ser en el mundo. Para ser más precisos nuestro ser femenino en la Argentina.

Varias son las preguntas que aparecen y que irán estructurando este trabajo:

¿Qué concepto de belleza se utiliza para los cuerpos femeninos en la televisión argentina? ¿Qué características físicas se reiteran en las mujeres que vemos en televisión? ¿Qué partes del cuerpo tienen mayor privilegio? ¿Qué se exhibe y que se oculta de esos cuerpos femeninos? ¿Qué estereotipos dominan la pantalla? ¿Qué tensiones crean los cuerpos femeninos que se exhiben?

¿Qué prácticas se forman alrededor de esos cuerpos femeninos que habitan la televisión actual? ¿Qué imágenes de mujeres se usan para las publicidades? ¿Qué se vende a través de esos cuerpos? ¿Qué palabras se utilizan para nombrar las partes corporales de mayor exhibicionismo?

¿Es el cuerpo femenino en los medios de comunicación masiva un dispositivo de control o es un medio para la liberación femenina? ¿Lo que están viendo ese casi millón de hogares argentinos refuerza los roles sociales tradicionales de la mujer o los quebranta? ¿En qué roles y con qué frecuencia aparecen mujeres en las pantallas? ¿Qué se dice sobre esos roles?

Nuestro país se nos presenta a veces como un río revuelto. Aquello de la biblia y el calefón no deja de tener sentido. Mientras algunos se vanaglorian con que una mujer argentina llega al poder otros sospechamos que en el mismo país la condición femenina sigue siendo funcional a la dominación masculina. Los patrones del patriarcado mantienen su vigencia a pesar de algunos pasos que unas cuantas mujeres dan hacia la liberación.

La condición de grupo dominado comienza a revertirse cuando nos reconocemos como grupo y reconocemos el poder que se ejerce hacia nosotras. Al parecer pensar en clave de liberación es cada día dar un primer paso.

Durante el año 2011 hubo 282 femicidios o sea que en la Argentina mueren cerca de 23,5 mujeres por mes víctimas de femicidio, "termino político que es la denuncia a la naturalización de la sociedad hacia la violencia sexista. El femicidio es una de las formas 
más extremas de violencia hacia las mujeres, es el asesinato cometido por un hombre hacia una mujer que considera de su propiedad".

Cada día una o varias mujeres son tratadas y exhibidas públicamente como mercancía apta de venderse o comprarse.

Hay en nuestro país trata de blancas.

Las mujeres somos tratadas como ciudadanos de segunda. Unidas y atravesadas por la pobreza, la vejez y la ignorancia. Las jóvenes y "bellas" son vendidas al mejor postor o convencidas de que su cuerpo joven y "bello" es lo único que tienen para triunfar.

De aquí surge que juventud, belleza y triunfo sean conceptos que debemos analizar.

Cada día volvemos a pensar en términos de patriarcado. Y ese mismo día deberíamos hacer el ejercicio de imaginar una manera de vivir en la diferencia y la igualdad. ¿Cómo hacer que esto suceda si llevamos miles de años bajo un sistema binario donde lo superior es lo masculino y lo inferior lo femenino?

Virgina Woolf en su ensayo "Profesiones para mujeres" cuenta dos experiencias que debió atravesar para trabajar en la profesión que ella eligió. Tomo estos ejemplos porque hablan desde los sentimientos de alguien que se reconoce como parte de un grupo dominado, comprende que su situación ha mejorado respecto a la mayoría de sus iguales pero no deja de saber que el camino hacia la libertad es difícil. Y digo libertad, no igualdad ni diferencia como desde los grupos feministas se batalla porque entiendo, como Woolf, que si simplemente cada mujer argentina fuera libre, se pensara libre de decidir, de pensar, de sentir, de accionar; las igualdades y las diferencias serian cuestiones de menor importancia. Cuando alguien ejerce sus libertades individuales nadie piensa ¿es igual a quien? ¿Es diferente a quien?. Individuos en un grupo. Cuerpos en sociedad es lo que somos en la modernidad. Iguales o diferentes el gran tema de las mujeres es acceder a la libertad. Y desde la libertad vivir la vida en el terreno que cada una elija.

Woolf atravesó, hace 80 años, por diversas experiencias que le permitieron convertirse en una profesional, en una mujer libre. Una de sus primeras experiencias fue el descubrimiento

\footnotetext{
${ }^{4}$ http://www.lacasadelencuentro.org/femicidios.html
} 
del fantasma del Ángel de la casa que le pedía hiciera callar sus pensamientos. "Es imposible reseñar siquiera una novela sin tener pensamiento propio, sin expresar la que a

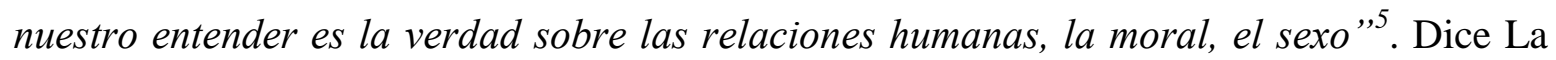
escritora que según el fantasma del Ángel de la Casa, las mujeres no pueden abordar libre y abiertamente todas estas cuestiones; deben encantar, deben conciliar, deben mentir para triunfar.

"Tener pensamiento propio" y "mentir para triunfar". Dos cuestiones que llegan hasta nuestros días y que tendremos en cuenta en esta investigación.

La otra experiencia que nos interesa en su camino a la libertad es la que describe como “una roca donde los dichos de las pasiones chocan”. Encuentra que el convencionalismo extremo del sexo opuesto constituye un impedimento. "La conciencia de lo que dirían los hombres sobre una mujer que dice la verdad acerca de sus pasiones la había despertado del estado de inconsciencia propia del artista. Ya no podía escribir" ${ }^{\text {.6 }}$. Me pregunto ¿las pasiones de las mujeres son dichas abiertamente? O mejor ¿las pasiones femeninas son expresadas públicamente? ¿Son aceptadas o rechazadas? Y por último ¿la conciencia del que dirán los hombres sigue funcionando?

En la Argentina las mujeres tenemos un largo camino a recorrer. Muchas logramos elegir nuestros trabajos, nuestras profesiones. Muchas acceden a cargos jerárquicos. Costeamos económicamente nuestras vidas. Muchas lo hacen por meritos propios, otras no, pero igual están allí, en situaciones de poder. Sin embargo la gran mayoría de las argentinas permanece bajo las órdenes de varones, a pesar de trabajar y de criar a sus hijos. La dominación masculina sigue ejerciéndose diariamente y a veces de manera brutal.

Si en el camino hacia la libertad hay mucho por recorrer debemos pensar también donde sigue anquilosada la transmisión de esta dominación. ¿Dónde se facilita esta transmisión? ¿Dónde las prácticas de dominación masculina tienen tanta publicidad? Mi mirada recae entonces en los medios de comunicación masiva. Radio, televisión, Internet, cartelera que invade las calles y nuestras casas. Hombres y mujeres desfilan vendiendo, diciendo,

\footnotetext{
${ }^{5}$ Woolf, Virginia. La muerte de la polilla y otros ensayos. Ed. La Bestia Equilátera. Buenos Aires 2012 ${ }^{6}$ Ibidem.
} 
haciendo. Que dicen, que venden, que hacen estos modelos que vemos diariamente millones de nosotros. ¿En estos modelos se funden varios tipos de mujer o solo uno?

Investigar profundamente los modelos femeninos que aparecen en los medios de comunicación masiva argentina es buscar certezas sobre lo que como sociedad estamos haciendo. Es buscar en lo que parecen simples cuestiones el nudo de grandes problemas. Es buscar hacia que caminos la sociedad argentina del 2011 empuja a las mujeres. Es intentar pensar "lo masivo" desde algunos autores que nos lleven a ver la verdad. Es salir en la búsqueda de dispositivos de control y de liberación. Es revisar las prácticas corporales: modos de pensar, de hacer y de sentir el cuerpo femenino. Es pensar. De esto se tratará este trabajo. 


\section{El Concepto de Cuerpo}

Comencemos por definir esta noción de cuerpo que va a iluminarse desde distintos ángulos, que se originan en algunos autores y en observaciones personales.

Un cuerpo único. Un cuerpo moderno que no está regido por instancias superiores. Una estructura anatómica - funcional que nos mantiene con vida. Es entonces la línea que divide la vida de la muerte. El cuerpo nace. El cuerpo muere. Y entre ambos procesos un volumen con el cual nos instalamos en el mundo. Volumen que nos separa del resto del mundo y a la vez nos ubica en él, está es la cuestión.

En el mundo nuestros actos y nuestro cuerpo se fusionan. Un cuerpo socialmente informado que funciona como generador y unificador de todas nuestras prácticas. Cuando hablamos de "socialmente informado" damos cuenta de todos los mandatos y aprendizajes culturales que se llevan adelante desde el nacimiento. Es en ese intercambio que los sujetos juegan un juego de creación. Es muy difícil definir una noción de cuerpo sino tenemos en cuenta este proceso. Somos como una obra de arte en proceso, en potencia, inventándonos a cada momento. Nacemos y vamos aprehendiendo el mundo que nos rodea a través de nuestros sentidos. Y a su vez el mundo nos aprehende a nosotros. En un juego de tensiones, aceptaciones y resistencias, se comienza a formar la subjetividad de cada uno que se va a evidenciar en una serie de performances y discursos, que a su vez, reflejaran los valores que el grupo social y cada uno le atribuyen al cuerpo.

Cada día en la recurrencia de las rutinas nos fundimos en un estar en el mundo. "En las condiciones habituales el cuerpo es transparente al sujeto que lo habita. Se desliza con fluidez de una tarea a otra, adopta los gestos socialmente admitidos, se hace permeable a los datos del medio a través de un tejido continuo de sensaciones"7 $\mathrm{y}$ en este hacerse transparente parece desaparecer y es tal vez el comienzo, al menos de la sensación, de dicotomía cuerpo/mente. Mientras el cerebro no se detiene y su presencia nos es evidente constantemente, el cuerpo como cuestión física, se nos vuelve invisible en lo cotidiano. No

\footnotetext{
${ }^{7}$ Le Bretton, David, Antropología del cuerpo y la modernidad. Buenos Aires: Nueva visión, 2002
} 
pensamos como respirar, no notamos nuestra postura en cada momento. No vemos nuestro cuerpo más que en un espejo y tal vez por eso lo olvidamos. Parecemos sujetos mentales disociados de nuestro cuerpo. Este pensamiento ha permitido construir grandes discursos en que el cuerpo es culpable de lo "moralmente negativo" y la mente la instancia inteligente. Sujetos bipolares o individuos con personalidades múltiples que solo pueden ser rescatados, contenidos y educados por discursos superiores como las religiones o el poder de los estados. El cuerpo subordinado a la mente.

Este pensamiento que podríamos llamar cuerpo/mente implica la subordinación del cuerpo en todos los sistemas de valores: religioso, moral y social de la cultura occidental tradicional. Y estos valores influyen en las prácticas médicas, educacionales y cotidianas de los occidentales. Desde nuestra vida privada, el amor, el sexo, la alimentación, la identidad hasta nuestra vida pública, el trabajo, el tiempo libre, las enfermedades, todo queda afectado bajo este paradigma

Dentro del paradigma cuerpo/mente quedamos envueltos en un mundo de dicotomías: hombre/mujer, dentro/fuera, emoción/razón, activo/pasivo, inferior/superior, sujeto/objeto. Donde las mujeres, dentro de la estructura patriarcal de la sociedad occidental, quedamos sumergidas en lo inferior, lo pasivo, lo emotivo, objetivizadas y colocadas exactamente dentro de los hogares. Hogares patriarcales.

Pero lo más intrincado de estas cuestiones. a nuestro juicio, es que dentro del binomio cuerpo/mente el cuerpo pasa a ser un objeto y la mente el sujeto. Pero si avanzamos un poco más, en nuestra sociedad androcéntrica, los hombres serían el sujeto y las mujeres el objeto. El cuerpo femenino llegaría a ser el objeto del objeto. Esta es la trampa. Porque si el cuerpo femenino es un objeto de un objeto (la mujer dentro del mundo masculino) el valor asignado será más bajo que el de un objeto y solo podrá elevarse según su valor de intercambio.

La maternidad fue un valor de intercambio codiciado, la fidelidad y la castidad fueron entonces esenciales para las mujeres ya que aseguraban la paternidad de la descendencia. Pero en estos tiempos luego de que la reproducción es controlada por la ciencia y las mujeres tienen acceso a ese avance el valor de la maternidad ha cambiado. Tampoco 
necesitamos poblar el mundo, ya lo hemos hecho. Ni sobrevivir es una misión, hemos subido la tasa de sobrevida de manera asombrosa en casi todos los países.

Entonces ¿Cuál es el valor de intercambio de este objeto/cuerpo femenino? Creemos que la respuesta esta en la sexualidad. El placer sexual es apreciado como algo al parecer difícil de alcanzar ya que de ser de fácil acceso su búsqueda no tendría tanto espacio en el mercado.

Cierto es que en nuestra sociedad el cuerpo femenino y su valor de intercambio como objeto de placer es altísimo. Una imagen de una "bella" (concepto que tendremos que retomar) mujer desnudándose mientras camina o bailando semidesnuda ante la mirada de millones de personas son de un valor de mercado sorprendentemente alto. Si en vez de una mujer fuera un chocolate, el ejemplo sería el siguiente: cuantos más seamos mirando el chocolate, mas lo deseamos y todos quisiéramos comprar ese chocolate o tal vez solo sería suficiente que los demás nos vean con ese chocolate en la mano.

Las mujeres son el producto de intercambio tal vez de más valor en el mercado actual, quizás porque esto tiene puntos inmorales ¿prohibidos? tal vez porque el placer en esta sociedad actual se nos escapa de las manos o simplemente porque la represión a nuestra sexualidad es aún muy fuerte. No es de nuestro dominio definir el porque de esta situación sino mucho más simple, destacarla. Hacerla pública una vez más.

Mientras el paradigma cuerpo/mente goce de algún prestigio, la mujer, el cuerpo femenino, se verá atrapado en un mercado que le exige ser un objeto que ofrezca, insinué y demuestre que es capaz de abastecer de placer a los demás. Esta sexualidad basada en la genitalidad femenina y en la dominación masculina del objeto/cuerpo femenino puede ser raíz de violencia, dolor y displacer de muchas personas, hombres o mujeres.

Por eso buscamos un concepto de cuerpo femenino que rompa la dicotomía cuerpo/mente, para salir de ese paradigma, que no fue y no es, dominante en el mundo entero ni en todos los tiempos.

Es relevante el estudio donde David Le Bretton hace un recorrido en la historia buscando la palabra cuerpo en civilizaciones anteriores. En este demuestra que el cuerpo no se separaba del ser y el ser estaba incluido en la naturaleza, o en el cosmos, así lo describe: "en las 
sociedades africanas la persona no está limitada por los contornos del cuerpo, encerrada en sí misma. Su piel y el espesor de su carne no dibujan las fronteras de su individualidad. Lo que nosotros entendemos por persona es concebido en las sociedades africanas como una forma compleja, plural. La oposición esencial está en la estructura holística de estas sociedades en las que el hombre no es un individuo (es decir indivisible y distinto) sino un nudo de relaciones. El hombre estaba fundido en una comunidad de destino en la que su relevancia personal no era indicio de una individualidad sino una diferencia que favorecía las necesarias complementariedades de la vida colectiva, un motivo singular dentro de la armonía diferencial del grupo" ${ }^{8}$. Por lo tanto en este tipo de sociedades es el grupo el que da el valor y el significado a cada individuo. Y cada individuo le suma a su grupo su relevancia personal simplemente su particularidad, su singularidad. El grupo es un cuerpo social.

Como trabajamos en la Argentina no queremos dejar pasar que en América el concepto de cuerpo también era diferente al actual. En un estudio de la sociedad náhualt del Altiplano Central de México (López Austin, 1996) la materialidad de las entidades anímicas en el pensamiento indígena eran tan patentes que resultaría imposible sostener la dicotomía cuerpo/alma. El cuerpo era vivido como un sitio sagrado, como una replica en miniatura del universo. La cabeza era el cielo, el diafragma la tierra., el corazón el sol; el individuo era un ser de naturaleza plural que se transformaba bajo la influencia de sus ancestros, de los astros, de las divinidades y del medio ambiente.

Por lo tanto la noción de cuerpo, tal como la pensamos nosotros es un efecto de la estructura individualista de nuestro campo social, una consecuencia de la ruptura de la persona con su colectividad y/o con el cosmos. Y en la actualidad el sujeto es un individuo aislado en un grupo. La modernidad trajo consigo una gran soledad, ya no somos esa comunidad ni esa banda avanzando por el mundo. Los grandes discursos religiosos, en occidente, no tienen la misma importancia que en siglos anteriores. Entonces en nuestras sociedades las personas formamos nuestra subjetividad con el cuerpo como frontera, es lo tangible de cada uno de nosotros cuando nuestros vínculos con la comunidad se desvanecieron. El cuerpo es nuestro arraigo al mundo y como tal genera vínculos, crea

${ }^{8}$ Ibidem

Página | 14 
símbolos que lo unen y lo separan de los demás individuos. Nos incluimos en algunos grupos y nos excluimos o nos excluyen de otros. Y en este juego de vínculos creamos nuestra subjetividad.

"La imagen del cuerpo no es un dato objetivo, no es un hecho, es un valor que resulta, esencialmente, de la influencia del medio y de la historia personal del sujeto. No hay nunca una apreciación bruta de las sensaciones del cuerpo, sino desciframiento, selección de los estímulos y atribución de un sentido" ". En este pensmiento vemos claramente el concepto de cuerpo informado que describíamos al principio de este capítulo. Hablamos entonces de sensaciones que son interpretadas. Formamos una imagen de nuestro cuerpo absolutamente impregnada de los saberes de la cultura a la cual pertenecemos. Donde la mirada de los “otros" pone en valor nuestras apreciaciones.

La clave es pensar que cada individuo de la misma sociedad responde a las pautas y mandatos de diferentes maneras. Y el cuerpo es la dimensión sensible y física de cada individuo. A través de las percepciones se someterá o se rebelara a los cuestionamientos sociales y en la superficie del cuerpo quedaran los signos que producirán la identidad y el reconocimiento social.

La solidez de nuestros músculos, la apariencia a través del vestuario, el conocimiento de algunas técnicas corporales, los adornos que utilicemos, los signos que indiquen juventud como la suavidad de la piel, la ausencia de arrugas en el rostro. La delgadez. Los tatuajes, el color del cabello, la manera de usarlo. Todos son símbolos de nuestra manera de incluirnos en ciertos grupos sociales y a su vez son respuestas al juego de percibir y dejarnos percibir por el mundo. El cuerpo es nuestra identidad y todo lo que hagamos tendrá consecuencias sobre nosotros mismos ya que modificara nuestra relación con el mundo. Agregar cosas al cuerpo como prótesis, implantes, aros, dibujos significara un agregado pero a la vez una perdida. Una parte de nosotros ya no volverá a ser igual. Una parte del cuerpo que se modifica o que se extirpa puede afectar toda nuestra existencia de acuerdo con la historia de cada uno y con la capacidad moral que tengamos para hacer el duelo e integrar un cuerpo extraño. Modificar el cuerpo es modificar al ser mismo.

\footnotetext{
${ }^{9}$ Ibidem
} 
El cambio en el concepto de cuerpo es profundo. Mientras bajo el paradigma cuerpo/mente la sociedad nos dictaba a cada uno como debíamos ser. Ahora las instituciones ya no gobiernan nuestro aspecto ni nuestro comportamiento como durante tanto tiempo lo hicieron las escuelas, los trabajos, la comunidad. Ya no estamos obligados, en occidente a adoptar los signos de pertenencia donde se categorizaban trabajos, religiones, orientaciones sexuales, artísticas. Hoy cada uno es responsable de su identidad y su imagen y lo manifiesta más con su cuerpo que con sus dichos. El cuerpo es hoy el que habla. Pero no habla como grupo sino como individuo. $Y$ es por eso que se hace imprescindible mostrarse, hacerse visible.

¿Qué hacemos visible de nuestro cuerpo las mujeres? ¿Cómo dialogamos con el viejo paradigma cuerpo/mente? ¿Qué signos adaptamos, a que categorías sociales adherimos? Para finalmente preguntarnos ¿las mujeres nos hemos revelado a ser el objeto del objeto/ sujeto? 
La grilla de observación

Durante los meses de julio y agosto de 2011 he realizado una observación en los cinco canales de la televisión abierta argentina, Telefe, América, 13, 9 y la TV Pública. Un seguimiento de los cinco programas que abarcan la franja horaria de $14 \mathrm{hs}$ a $16 \mathrm{hs}$ teniendo como objetivo reconocer y registrar los cuerpos femeninos. Semejanzas, coincidencias, diferencias, modas, rarezas, discursos. ¿Podremos tener un solo cuerpo que los representen o necesitaremos más de uno para representarlos a todos?

A partir de ahora construiremos un concepto de cuerpo a través de referentes empíricos, por lo cual nuestras observaciones se inscribieron en una grilla armada especialmente. Buscamos dimensiones del cuerpo que pudieran darnos indicadores que derivaran en valores concretos (definiciones operativas) esas dimensiones son:

"estereotipos" analizaremos aquí la pertenencia que tienen estos cuerpos a tres grandes grupos que referirán la procedencia geográfica de las personas:

\section{Asiáticas - indoamericanas - europeas}

Estos indicadores se basaran en los biotipos que se han tornado estereotipos para las mujeres originarias de cada zona geográfica. Nos apoyaremos en el concepto de población: la representación que de una mujer se tiene en el imaginario colectivo que refiere a una zona geográfica por ejemplo: los ojos rasgados se vinculan con China/Japon aunque esa persona haya nacido en nuestro país. Ubicamos en grupos poblaciones a cada una de las mujeres para buscar si hay un solo estereotipo que aparece en la televisión argentina o varios; a cuales se dejan afuera y en que porcentaje participa cada uno. La pregunta es ¿qué estilos de mujer están en la televisión argentina y cuales quedan fuera de ella? ¿las mujeres en la televisión argentina reflejan a la población en general? ¿o son un indicio de un ideal que se quisiera alcanzar?. Apoyados en las publicaciones del censo 2010 para saber la verdadera composición de la población de Buenos Aires y Gran Buenos Aires veremos entonces cual es el resultado. 
En definitiva para pertenecer a estos grupos cada una deberá tener mayoritariamente marcado en el rostro, como así también en otras partes del cuerpo, la imagen estereotipada de quienes sean originarios de cada zona geografía, por ejemplo las americanas deberán tener mayoritariamente los rasgos estereotipados de las mujeres que vivían en América antes de la conquista.

Indoamericanas:

- ojos castaños, cabellos gruesos y lacios, piel de tonos dorados, bocas carnosas, narices anchas, ojos rasgados, rostros redondos, cuerpos voluptuosos, caderas anchas, pechos grandes. Ejemplos Catherine Fulop, Jennifer López, Julieta Ortega, Belén Blanco.

Asiáticas:

- ojos rasgados, cabellos lacios, nariz ancha, piel de tonos amarillos, labios gruesos. Cuerpos delgados, pechos pequeños o medianos, caderas pequeñas. Ejemplos Lucy Liu, Sandra Oh, Natalia Kim.

Europeas:

- ojos claros, cabellos finos y claros, narices finas, piel blanca. Cuerpos magros, longilineos Ejemplos Carmeron Diaz, Penelope Cruz, Ana Belen, Jennifer Aniston.

Cualquier intervención que se haga en el cuerpo será tenida en cuenta ya que lo que buscamos es la imagen que cada una da a los demás, pensando en que si ha intervenido su cuerpo para pertenecer a otro estereotipo simboliza su deseo y su participación a esa imagen, en ese caso no nos interesa su origen sino la imagen actual. El reconocimiento que cada mujer haga sobre su cuerpo indicara a que grupo pertenece.

Siguiendo la grilla de observación los siguientes ítems son: 


\section{Edades}

- analizaré las franjas etarias que más se visualizan y cuales menos. En este ítem los indicadores serán: hasta 20 años / entre 20 y 30 años / entre 30 y 40 / entre 40 y 50 / más de 50

El cálculo para colocarlas es a simple vista pero cuando surgieron dudas busqué la edad en internet. Me pareció importante distinguir cada 10 años ya que aparentemente ser joven es más una virtud que una etapa. Por eso debí hacer finita la división de edades para buscar mayor detalle. La pregunta que surge es ¿de qué edad son las mujeres que aparecen en la televisión argentina y cuáles quedan fuera de ella?

\section{Partes del cuerpo visibles}

- buscamos que partes del cuerpo muestran estas mujeres, para ver también que partes quedan ocultas. Tomaremos tres indicadores: Cara / pechos / piernas.

Recordemos que en la televisión hay voces femeninas en off en publicidades y en programas ${ }^{10}$ por lo tanto es preciso definir si se ve la cara de las mujeres. Los otros dos puntos incluyen a la parte superior (pechos- cuello -hombros) y a la parte inferior del cuerpo (piernas - cola - pies).

\section{Tez}

- los colores de la piel son símbolos de etnias, de status social, de racismo En este trabajo fueron pensados totalmente asociados a los estereotipos. Pero es necesario separar estereotipo de carga o jerarquía social y solo relacionarlo a europeas indoamericanas - asiáticas.: blanca / dorada / amarilla

- en ese orden.

Busco establecer si la diversidad de tonos de piel está incluida en la imagen de la mujer o no lo está. ¿Qué tonos de piel se privilegian para mostrar por televisión y

\footnotetext{
${ }^{10}$ Un ejemplo fue durante muchos años el programa Show match tenía un formato con un conductor frente a la cámara y una voz femenina en off que lo acompañaba, comentaba, preguntaba, etc
} 
cuáles no? ¿Cuáles coinciden con los estereotipos marcados? ¿Cuáles coinciden con la población en general?

\section{Peso corporal}

- Aquí veremos en qué lugar se ubicaran estos cuerpos refiriéndose al peso: Delgadez extrema-delgada - media - gruesa

En delgadez extrema estarán situadas aquellas mujeres que su peso sea sospechoso de ser menor de lo normal, brazos muy delgados que marquen los huesos sobre todo en los hombros, rostros con las mandíbulas muy marcadas, todas las articulaciones evidentes en el cuerpo.

En delgada estarán la de bajo peso. En media estarán las que estén en su peso o un poco más arriba y finalmente en gruesa las que tengan exceso de peso.

\section{Tono muscular}

- esto indicará además de cuestiones genéticas, que no importan demasiado, la actividad física de estas mujeres. Siendo el punto fuerte el que demuestre el entrenamiento y el débil la ausencia del mismo:

débil - medio - fuerte

\section{Tamaño de los pechos}

- En la actualidad parece que esta dimensión es muy importante. Con el gran auge de cirugías plásticas se busca verificar esta sensación general de que las mayoría de las mujeres tienen puestas siliconas en el pecho por lo los pechos se tabularan a como: Grandes / medianos / chicos

El indicador grande se cruzará con el peso corporal para ver si las mujeres que intervienen su cuerpo en los pechos también lo hacen con su peso corporal. 
Continúo con algunos puntos estratégicos que tienen que ver con la moda mundial que generalmente tienen un anclaje en la vida social de los individuos, recordemos por ejemplo en 1920 cuando la moda femenina impuso el cabello bien corto "a la garçonne", las polleras justo después de las rodillas, el uso de la combinación como ropa interior femenina, la seda o símil que no necesitaba plancha. Motivado todo por una novela donde la protagonista comienza a transgredir las normas de la moral burguesa: fuma, bebe, se incorpora al mercado laboral, tiene relaciones sexuales con quien quiere. Se instala un punto de inflexión que no volverá atrás. Las mujeres de la década del 20 son las protagonistas de un cambio, lo exigen y lo muestran en sus cuerpos ¿habría otro lugar mejor que el cuerpo para generar semejante subversión? Esta moda se instala en las calles. Signos que señalan el comienzo de cambios profundos sobre la sexualidad, el poder económico y las libertadas civiles de las mujeres. Tal vez hayan simbolizado el deseo de libertad del colectivo de mujeres.

¿Pero qué signos vemos ahora en el cabello, el peinado, el maquillaje de las mujeres actuales? Por esto nuestra grilla observara los siguientes indicadores:

\section{Cabello}

- Observaremos el largo, el color y los peinados: lacio / rulos; rubio / castaño / rojo; suelto / atado

\section{Maquillaje}

- Mucho-medio-poco

Hasta aquí la grilla recaba información sobre la parte visual de esos cuerpos femeninos. Pero también queremos saber en que lugares se ubican esos cuerpos: ¿Qué dicen? ¿Qué hacen? ¿Cómo se mueven? ¿Qué intentan representar? Observaremos entonces:

\section{Participación oral}

- Su participación de manera oral es: activa / media / escasa. Si cuando lo hacen hablan en tonos de voz: alto / medio / bajo

\section{Conductas que realizan:}




\section{Explicar / interrogar / liderar / ordenar / obedecer / enseñar / trabajar / sujeto erótico / vender placer / vender objetos / bailar}

Cuando digo explicar, sucede que muchas de esas situaciones se refieren a los chimentos, la palabra adecuada sería comentar sin embargo uso explicar porque se incluyen también algunas explicaciones por ejemplo de notas en exterior o cronistas que se referían a otros temas.

Un apartado merece el ítem sujeto erótico su definición y su rol. Fue necesario encuadrar algunos cuerpos que se destacan por el nivel de exhibición de algunas partes como los senos, los glúteos y las piernas en programas de tv donde esta exposición no se condice con el contenido. Tiene que ver con el uso de ropa muy ceñida, escotes pronunciados, polleras cortas, tacos altísimos. Son cuerpos se exhiben más de lo usual, podríamos decir que son cuerpos en función de exhibirse. Y no son solo las partes del cuerpo que se exhiben, lo que se detecta, sino la manera de hacerlo, el lugar donde lo hacen. Cuerpos con una saturación de signos eróticos, lo que parece ser la mercantilización de estos CF.

Como una gimnasta en su coreografía cada parte del cuerpo esta vestida y en la pose necesaria para lograr ese objetivo.

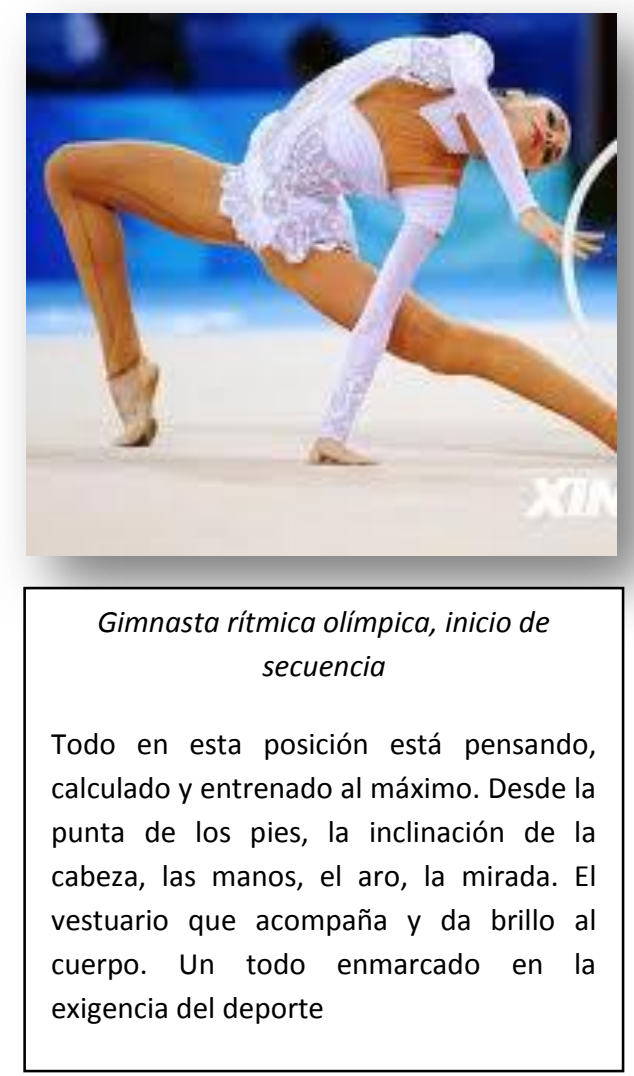




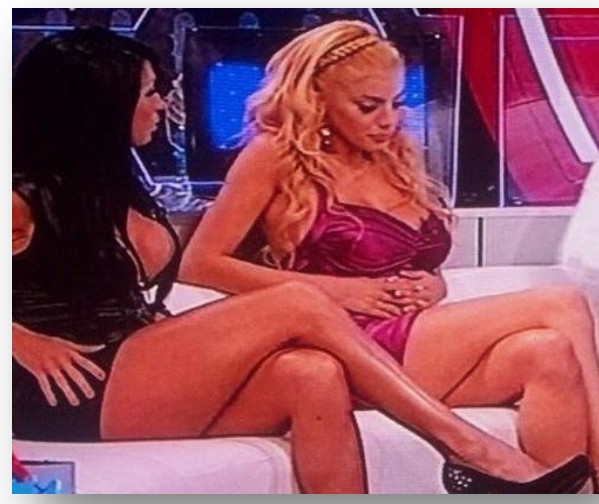

Vedettes participando en un programa como invitadas.

En la pose de estas mujeres parece también estar todo pensado, calculado. La manera de sentarse con las piernas cruzadas, la extensión de la espalda, el abdomen escondido. La ropa que muestra las piernas, el escote que encuentra a la cámara. El brillo en la piel, el cabello rodeando el pecho. Nada es azar en la pose de las vedette sino más bien un juego pensado para las cámaras de tv.

Es un cuerpo acompañado de una actitud: un aparente nivel intelectual bajo, escasos y grotescos movimientos que podríamos decir que son gestos, como si estuvieran posando para ser fotografiadas, con poca participación verbal.

Generalmente esta imagen esta asociada a las llamadas vedette ${ }^{11}$ (artista principal de un espectáculo), que lejos de su definición se trata de personas con una fama efímera, las que de manera irónica se llaman "stars" o vedetongas.

Evocan al sexo de una manera muy nueva, desinhibida pero rígida a la vez. En un territorio aun confuso estos CF muestran un sexo oculto pero a la vez revelado. Un sexo que se sugiere o se presupone se cambia, en la clandestinidad por regalos, plata, viajes, matrimonios, puestos de trabajo y publicidad. Son personajes que venden historias de amores cortos, algunos fulminantes, cuentan historias sobre la performance sexual de

\footnotetext{
${ }^{11}$ http://www.elmundo.es/diccionarios/
} 
muchos hombres mediáticos y sobre la de ellas mismas, bailan, cantan y se desnudan. Llegan a los más altos puntos de rating. Siempre bajo la sospecha de prostitución parecen ser necesarias para que algunos programas sean exitosos. Repudiadas y reclamadas a vez. Encarnan un modelo femenino ligado exclusivamente al sexo y a contratos sexuales que no todas las mujeres están dispuestas a asumir pero que muchas imitan.

Tienen un concepto de belleza relacionado al volumen: cuanto más, más linda es. Son como el exagerado de la mujer común. Mas rubias, mas lacias, mas blancas, mas desnudas, mas tetonas, más delgadas, mas apretadas, más osadas, mas deseosas (¿deseo o pose?).

Estos CF son una de las nuevas prácticas femeninas ¿Qué participación tienen en el nuevo orden sexual? ¿Son participes de la realidad sexual argentina o son un condimento de ella? ¿Son las otras ó participan del colectivo de mujeres argentinas de hoy? Es lo que intento determinar en esta etapa de investigación. 
Las mujeres que trabajan en la televisión argentina de 14 a 16 hs durante los días de la semana los meses de julio y agosto de 2011
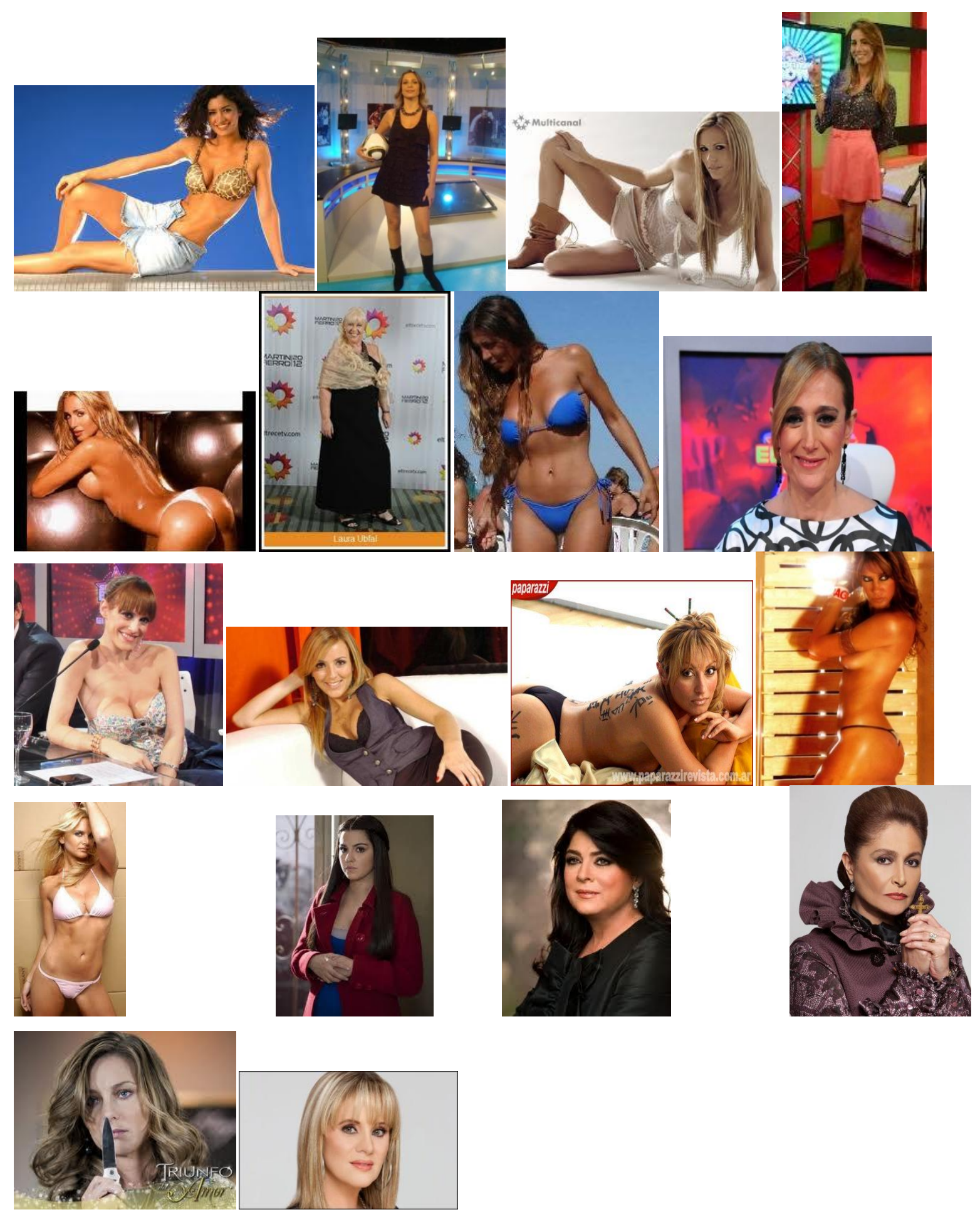
Para sacar conclusiones de que mujeres trabajaron cada día en esta franja horaria en los canales de aire y como la televisión es visual, he colocado fotos de todas ellas en la página anterior. Se eligieron fotos al azar utilizando las que aparecían primero en Google imágenes al colocar solo el nombre de cada una de ellas en el buscador; menos en el caso de las actrices de las novelas mejicanas donde también se buscó por el titulo de la novela, ya que considero que las actrices no son conocidas en la Argentina por su vida privada y llegan al televidente como el personaje que interpretan, por ello use la imagen que se vio de ellas durante la novela. Su vida privada, sus nombres, su devenir queda excluido en este trabajo porque es desconocido en nuestro país. Tomamos en esta parte solo 5 personajes por ser los que más participación tuvieron durante la observación. Sin embargo hay que hacer una salvedad, hubo, en la novela que se da en la franja estudiada, la participación de una argentina conocida como vedette, modelo y actriz, y se detectó que, aunque, su personaje no se diferencia de las demás mujeres de la novela, su foto tiene una imagen sexy y espontanea con la cual los argentinos estamos acostumbrados a verla.

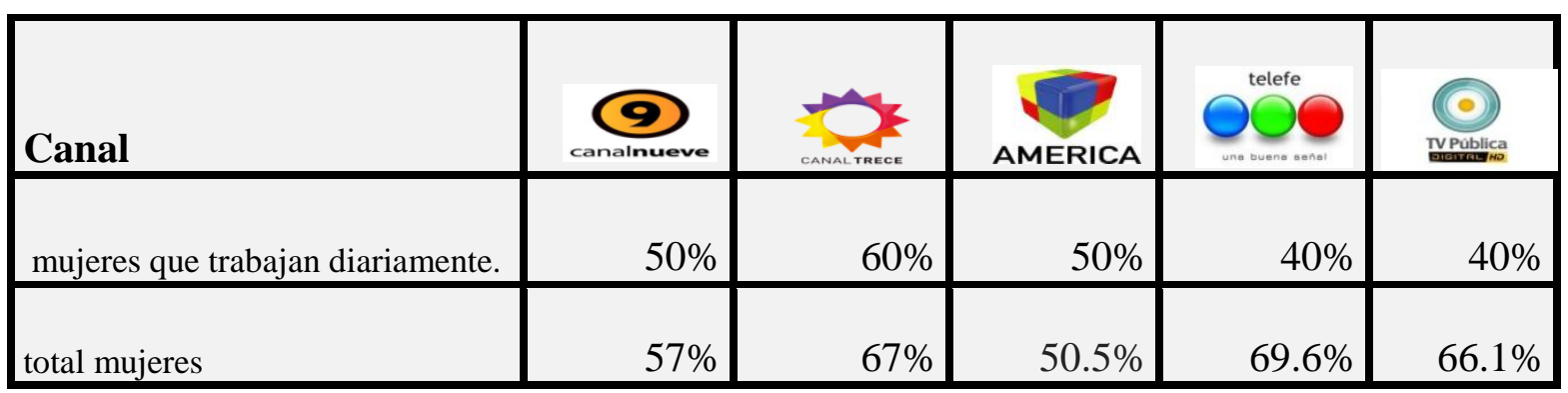

Son en total 18 mujeres sobre 34 personas que vemos fijas en la tv, entonces más de la mitad son mujeres.

\begin{tabular}{|l|l|l|r|}
\hline estereotipo & Asiáticas & 0 & $0 \%$ \\
\hline & Indo-americanas & 4 & $22.2 \%$ \\
\hline & Europeas & 14 & $77.7 \%$ \\
\hline
\end{tabular}

Encontramos que la mayoría son europeas, de las americanas son 3 de la telenovela mexicana y una argentina. Y no hay ninguna asiática ni africanas por lo que tampoco se encuentran representadas las mujeres que en tienen rasgos indígenas. 


\begin{tabular}{|l|l|r|r|}
\hline tez & blanca & 14 & $77,7 \%$ \\
\hline & dorada & 4 & $22.2 \%$ \\
\hline & amarilla & 0 & $0 \%$ \\
\hline
\end{tabular}

La tez nos coincide con los estereotipos.

\begin{tabular}{|l|l|r|r|}
\hline edades & $15-20$ & 0 & $0 \%$ \\
\hline & $20-30$ & 2 & $11.1 \%$ \\
\hline & $30-40$ & 9 & $50 \%$ \\
\hline & $40-50$ & 4 & $22.2 \%$ \\
\hline & 50 & 3 & $16.6 \%$ \\
\hline
\end{tabular}

Tienen entre los 25 y 55 años. El promedio de edad es de 37 años, la media es 33 años y la moda es de 30 años.

Las partes del cuerpo que muestran son la cara, los brazos, manos, la piernas con alguna pollera desde la rodilla o un poco mas arriba y alguna vez un escote osado. No hay short ni minifaldas, ni mallas que dejen al descubierto los muslos. No se hacen visibles los glúteos en ninguna oportunidad. Los escotes no pasan de ser escotes. Vestidas siempre muy formales, con tacos altos y algunos brillos las mujeres que trabajan diariamente en esta franja horaria no exhiben sus cuerpos más que cualquier mujer en la ciudad. Sin embargo cuando buscamos las fotos nos encontramos que de las 13 argentinas 9 de ellas han posado en ropa interior o desnudas para al menos una sesión de fotografía. Y la pregunta se cae de madura ¿era esto necesario? ¿era necesario para quien, para el rating o para ellas?

En la dimensión del peso encontramos

\begin{tabular}{|l|l|r|r|}
\hline peso corporal & delgadez extrema & 3 & $\mathbf{1 6 . 6 \%}$ \\
\hline & delgada & 12 & $\mathbf{6 6 . 6 \%}$ \\
\hline & media & 2 & $11.1 \%$ \\
\hline & gruesa & 1 & $5.55 \%$ \\
\hline
\end{tabular}


Notamos que entre las 3 de delgadez extrema y las 12 delgadas llegan al $83 \%$ del total.

\begin{tabular}{|l|l|r|r|}
\hline tono muscular & debil & 5 & $\mathbf{2 7 . 7 \%}$ \\
\hline & medio & 10 & $\mathbf{5 5 . 5 \%}$ \\
\hline & fuerte & 3 & $16.6 \%$ \\
\hline
\end{tabular}

Más de la mitad tienen un tono muscular que no parece tener entrenamiento o tal vez no excede las 3 sesiones semanales del mismo. La mayoría la vemos entre el medio y el débil.

\begin{tabular}{|l|l|r|r|}
\hline $\begin{array}{l}\text { tamaño } \\
\text { pechos }\end{array}$ & grande & 7 & $\mathbf{3 8 . 8 \%}$ \\
\hline & medio & 7 & $\mathbf{3 8 . 8 \%}$ \\
\hline & chico & 4 & $22.2 \%$ \\
\hline
\end{tabular}

La mayoría de las mujeres tienen pechos medianos o grandes

\begin{tabular}{|l|l|r|r|}
\hline cabello. Tipo & lacio & 18 & $100 \%$ \\
\hline & rulos & 0 & $0 \%$ \\
\hline cabello. Color & rubio & 12 & $66.6 \%$ \\
\hline & castaño & 5 & $27.7 \%$ \\
\hline & rojo & 1 & $5.5 \%$ \\
\hline cabello. Peinado & suelto & 16 & $88.8 \%$ \\
\hline & atado & 2 & $11.1 \%$ \\
\hline
\end{tabular}

El indicar lacio es un representante exacto de todas las mujeres y en el color debemos resaltar que entre las argentinas solo hay dos castañas, las otras 3 son mexicanas. Lo que hace pensar sin esa novela las rubias hubieran acompañado casi por un $90 \%$ al indicador lacio. Rubias de pelo lacio podría ser el un símbolo de pertenencia a la belleza y probablemente a un grupo social con más jerarquía, ya que de las 13 rubias ninguna lo es de manera natural. 


\begin{tabular}{|r|l|r|r|}
\hline maquillaje & mucho & 11 & $61.1 \%$ \\
\hline & medio & 4 & $22.2 \%$ \\
\hline & poco & 3 & $16.6 \%$ \\
\hline
\end{tabular}

La mayoría trabaja con mucho maquillaje

Entonces hasta ahora entre las mujeres que trabajan en esta franja horaria en la televisión de aire de la Argentina, las características que más se reiteran son:

Europea, blanca, delgada, con tono muscular normal o tenue, de pechos grandes, rubia de cabellos lacios y muy maquillada, de unos 30 años.

Veamos ahora como hablan y que hacen en la pantalla, en números y porcentajes.

\begin{tabular}{|l|l|r|r|}
\hline hablan & mucho & 1 & 5.5 \\
\hline & medio & 5 & 27.7 \\
\hline & poco & 12 & 66.6 \\
\hline & & & \\
\hline voz & alta & 8 & 44.4 \\
\hline & moderada & 6 & 33.3 \\
\hline & baja & 4 & 22.2 \\
\hline
\end{tabular}

La mayoría entonces oralmente participa poco y en un tono de voz moderado o bajo. 


\begin{tabular}{|l|l|r|r|}
\hline conductas & interroga & 11 & $61.1 \%$ \\
\hline & *explica & 7 & $38.8 \%$ \\
\hline & lidera & 4 & $22.2 \%$ \\
\hline & ordena & 2 & $11.1 \%$ \\
\hline & obedece & 2 & $11.1 \%$ \\
\hline & enseña & 1 & $5.5 \%$ \\
\hline & aprende & 0 & $0 \%$ \\
\hline & sujeto erótico & 3 & $16.6 \%$ \\
\hline & profesional & 17 & $94.4 \%$ \\
\hline & universitarias & 2 & $11.1 \%$ \\
\hline & Trabaja & 18 & $100 \%$ \\
\hline & ofrece placer & 0 & $0 \%$ \\
\hline & ofrece objetos & 0 & $0 \%$ \\
\hline
\end{tabular}

De las 4 que lideran tres son los personajes de la novela mexicana y de las dos que ordenan las dos son de esa novela. Ninguna de las argentinas ocupa el rol principal o protagonista. El 64\% interroga y un escaso 33\% comenta o explica alguna cuestión. Ninguna aprende y el 5\% puede enseñar algo. Estas mujeres parecen tener el rol mayoritario de interroga.

Profesionalmente hay 6 actrices, 6 periodistas, 4 modelos y/o vedette, 1 locutora y 1 no sabemos. Solo dos estudiaron en la universidad, no sabemos si completaron sus estudios.

Laboralmente hay 3 co-conductoras, 7 panelistas, 2 cronistas y 6 actrices. Por lo tanto en este ítem podría decir que las 6 actrices producen un personaje, pero entre las argentinas si tomamos la co-conducción como un acompañamiento, como la partenaire no habría una producción de algo propio sino en todo caso en equipo, mas las que trabajan de panelistas donde lo que hacen es escuchar y ver el programa como cualquier televidente pero pueden participar se supone que a veces para dar pie en un tema o decir algunas cosas que no sería apropiado en los conductores o simplemente dar opinión; no se ve en esto una producción, una creación, una puesta en juego de algo propio, no se puede determinar que y cuanto cada una de ellas es capaz de hacer o de decir. Cuando uno investiga sus vidas personales no deja de pensar en que hay mucho más de estas mujeres que no está siendo puesto en juego. ¿ellas pueden revertir esta situación? ¿pueden lanzarse a investigar, a trabajar más a fondo? ¿Qué los programas sean de entretenimiento abrevia la profundidad de los debates? ¿la limitación de sus comentarios es por ellas, por su nivel intelectual, es por pedido de quienes 
las contratan? Y por último estas mujeres que están en la pantalla todos los días podrían estar compitiendo para acceder a roles mas importantes o principales ¿lo están haciendo?

Volvamos a las 7 panelistas, ocupan el rol de quienes escuchan y preguntan para simplemente saber algo de alguien. Una especie de inquisición, de observador omnipresente porque no es a ellas a quienes se presentan las diferentes situaciones pero siempre están ahí, acechando, controlando, juzgando. Al costado de la acción principal observan. Se podría encontrar una analogía con el rol de las vecinas de los conventillos que espiaban los aconteceres del lugar siempre dispuestas a intervenir si era necesario.

La definición de panelista refiere a una persona o grupo de personas que discuten una cosa públicamente. Generalmente se buscan especialistas para cada discusión. Sin embargo en los programas analizados la discusión no siempre se instala en el panel, sino con él o los conductores. Por lo tanto esto convierte a estas panelistas en panelistas de $2^{\circ} \mathrm{o}$ de relleno y en expertas en chimentos, en criticar y someter a discusión hechos y sucesos de la vida privada de las personas.

Si tomamos las características como cuerpos femeninos se pueden definir de la siguiente manera: blancas, trabajadoras y heterosexuales, o sea, todas son de un grupo dominante (blancas sin las diversidades), pertenecen a una misma clase social (trabajadoras de buen salario) y adscriben a la hetero-normatividad. Se puede pensar que ellas representan un habitus. Una forma de pensar, de actuar, de sentir resultante de la articulación de lo individual y lo social, donde se unen las estructuras internas de la subjetividad y las estructuras sociales externas. El habitus siguiendo a Bourdieu es una subjetividad socializada producto de la interiorización de una multiplicidad de estructuras externas que a pesar de operar racional y prácticamente es inconsciente.

Un habitus totalmente funcional al patriarcado. Parecidas hasta lograr estereotiparse, ocupan un mismo nicho de acciones, sus razonamientos no están muy alejados conceptualmente, sus dichos pocos profundos no innovan ni cuestionan. No muestran roles diferentes, no acentúan sus rasgos distintos ni defienden nuevas banderas. 


\section{El CF en la televisión}

\section{La observación general}

Cuando se pasan los datos a una planilla general ya el primer punto dice algo:

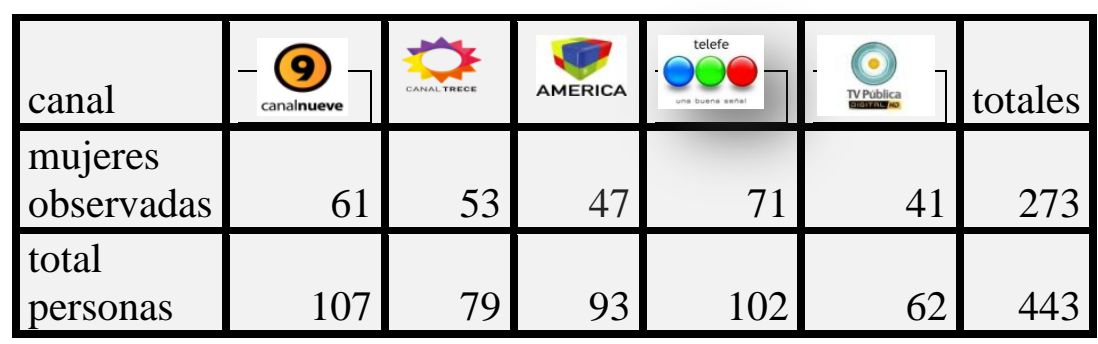

Más de la mitad, exactamente el $61,1 \%$ de las personas que participan en los programas de la televisión abierta de esta franja horaria son mujeres. El canal en el cual vemos más es el 9 donde se transmite una telenovela mexicana. En todos los canales la participación femenina es mayor que la masculina. La mayoría de la programación es de interés general.

\begin{tabular}{|c|c|c|c|c|c|c|c|}
\hline canal & & (9) & Yes & $\sqrt{5}$ & $0^{\text {telefer }}$ & (2) & \\
\hline \multirow{3}{*}{ estereotipo } & asiáticas & $0 \%$ & $0 \%$ & $0 \%$ & $0 \%$ & $0 \%$ & $0 \%$ \\
\hline & americanas & $27 \%$ & $3.7 \%$ & $0 \%$ & $2.8 \%$ & $2.4 \%$ & $7.1 \%$ \\
\hline & europea & $44 \%$ & $96.2 \%$ & $100 \%$ & $97.1 \%$ & $97.5 \%$ & $\begin{array}{r}86.96 \\
\% \\
\end{array}$ \\
\hline \multirow[t]{2}{*}{ tez } & blanca & $78.6 \%$ & $96.2 \%$ & $97.8 \%$ & $97.1 \%$ & $97.5 \%$ & $\begin{array}{r}93.4 \\
\%\end{array}$ \\
\hline & dorada & $21.3 \%$ & $3.7 \%$ & $2.1 \%$ & $2.8 \%$ & $2.4 \%$ & $6.4 \%$ \\
\hline
\end{tabular}

No hay ninguna mujer que represente el estereotipo asiático.

No hay ninguna mujer que represente tez oscura. 
El porcentaje de representantes americanas en total es de 7,1\%. Se nota claramente que el porcentaje aumenta por el canal 9 que transmite la telenovela mexicana. Si tomara solamente las producciones argentinas de los cuatro canales restantes tendría como resultado que las representantes de este estereotipo serian el 2,2\%, llegando al extremo de América con el 0\%. Sin embargo en la Argentina la población indígena según el Instituto Nacional de Estadísticas y Censos (INDEC) en los resultados de la encuesta complementaria de Pueblos Indígenas 2004-2005 (ECPI) estima que hay 600.329 personas que se reconocen pertenecientes y/o descendientes en primera generación de pueblos indígenas. Resulta extraño y no se encontraron respuestas de porque solo se rastrea hasta la primera generación. En el censo 2010 los resultados son nuevamente extraños. El censo incluía pueblos originarios pero dice: “con respecto a su consulta, le informamos que a partir de la incorporación de la temáticas como la discapacidad, pueblos originarios y afro descendientes en el Censo Nacional de Población Hogares y Viviendas del año 2010, se realizaran Encuestas Complementarias, una vez finalizada la publicación total del mismo"12. En el Informe Anaya ${ }^{13}$ se detecta que se ha vuelto a omitir la pregunta sobre la descendencia de pueblos originarios en el formulario general y que lo que se ha realizado en el Censo 2010 es un formulario ampliado, de tipo muestrario, siendo absolutamente minoritario respecto al general y que por la forma en que fueron distribuidos carecían de la capacidad de mostrar la realidad indígena del país.

Entonces ¿Cuál es la población total de personas que descienden de pueblos originarios? ¿Estas personas tendrán el mismo concepto de belleza que los europeos? ¿Podemos rastrear el concepto de belleza en nuestro país ignorando los estereotipos indoamericanos? ¿Qué cantidad de mujeres quedan afuera de esta imagen de mujeres europeas que vemos diariamente en la televisión abierta?

Dos situaciones actuales que suceden a nuestro alrededor: Al lado de mi casa construyen otra casa, los muchachos trabajan animadamente, charlan. No llegamos a comprender que dicen hasta que entendemos que hablan otro idioma ¿alemán? No guaraní. Me piden agua,

\footnotetext{
${ }^{12}$ Mail recibido el jueves 26 de abril de 2011 de parte de Fabiana Esses, Instituto Nacional de Estadistica y Censos, Centro Estadístico de Servicios, Av Roca 609, Ciudad de Buenos Aires, Argentina - htpp://www.indec.mecon.gov.ar

13“"Informe sobre la situación de los Pueblos Indígenas en Argentina: la agenda pendiente. Para el relator de Pueblos Indígenas James Anaya. Diciembre 2011".http://odhpi.org/wp-content/uploads/2012/01/Informe-a-Anaya2011-sobreArgentina.pdf(pag 3 de dicho informe)
} 
comentamos cosas, durante un año compartimos amablemente el espacio lindero. Ellos son bilingües, nosotros no. No nos atrevemos a preguntar de donde son pero sabemos que viven en Argentina, tienen hijos, novias, algunos estudian.

La otra situación sucede en un consultorio privado de medicina de City Bell, la Dra. que nos atiende mide cerca de 1,85 o más, tiene cabellos negros y gruesos, algunos rulos, nariz algo ancha y larga, boca grande, manos y pies grandes. Universitaria, argentina, recuerda las descripciones en grabados, dibujos y textos de los Aonikenk (Patagones Meridionales) durante los siglos XVI, XVII y XVIII.

La sensación de que los pueblos originarios están presentes en la población actual y no son solo aquellos que están dentro de las organizaciones comunitarias actuales, como el reduccionismo occidental pretende que creamos. Por ejemplo la comunidad Currumil en Neuquen o LhakaHonhat en Salta. Sigo buscando huellas de estas gentes que si son una cantidad importante modificaría o debería haber modificado los estándares, pero evidentemente se actúa sobre el concepto de belleza que el estereotipo europeo grita desde la televisión.

Volvemos al censo 2011 el 13,2\% de población de la ciudad de Buenos Aires es inmigrante de Paraguay y Bolivia mientras que en el gran Buenos Aires el 7,5\% son inmigrantes de esos países. Ahí están representados tal vez nuestros vecinos. Otro estudio esclarece aun más esta cuestión:

El Dr Daniel Corach es biólogo y genetista argentino, creador y director del Servicio de Huellas Digitales Genéticas de la Universidad de Buenos Aires. Este servicio hace un estudio, -que se pregunta al igual que nosotros-, cuanto había aportado la población originaria en la formación de la actual Argentina. Ellos buscaron la respuesta en la genética de nuestra población ¿tan profundo tenemos que llegar para encontrarnos? La investigación ${ }^{14}$ interpreto los códigos del cromosoma Y donde hay un marcador (DYS199) que en el caso de los amerindios aparece con una característica típica y científicamente probada, los hombres lo transmiten a sus hijos y este se mantiene inalterable de generación

\footnotetext{
${ }^{14}$ http://portal.redargentina.com/foros/el-56-de-loa-argentinos-tiene-ancestros-indigenas http://www.pagina12.com.ar/diario/ciencia/19-54853-2005-08-10.html http://www.ffyb.uba.ar/gxpsites/hgxpp001.aspx?2,1,1605,O,S,0,PAG;CONC;1609;6;D;2178;1;PAG http://www.scielo.org.ar/pdf/medba/v66n2/v66n2a04.pdf
} 
en generación. Lo mismo sucede en una zona del ADN mitocondrial de las mujeres. Los resultados arrojaron que un $60 \%$ de la población Argentina tiene componentes amerindios, de ese porcentaje solo un $10 \%$ no tiene ningún componente europeo.

Al respecto Corach dice: "-Sesenta por ciento. Y esto se refleja mejor en el ADN que viene por línea materna (el ADN mitocondrial) que el paterno (el del cromosoma Y), porque el mestizaje se hizo básicamente sobre el vientre materno. Las mujeres eran violadas. Era más fácil que un español violara a una india que una española se cruzara con un indio. Los indios hombres eran apartados, explotados hasta la muerte o exterminados. Exterminio y explotación son variables que se repiten en toda América latina. Y la conclusión en la Argentina es clara: todos tendemos hacia el amerindio. Aunque haya sectores de la sociedad que se animan a negarlo"

Los sectores sociales que lo niegan evidentemente tienen una amplia influencia en los medios de televisión masiva, Llegado este punto puedo afirmar que hemos encontrado el primer sesgo hacia una población homogénea blanca europea quedando fuera de esta imagen televisiva el $60 \%$ de nuestro componente nativo Argentino; en los bordes también quedan las pieles oscuras y los rasgos asiáticos.

No dejo pasar el comentario de Corach sobre "el vientre materno" que llamaré en adelante el cuerpo de las mujeres. ¿Tendrá relación este inicio violento en la negación del estereotipo americano? ¿Para estos niños y niñas nacidos de violaciones fue necesario olvidar para incorporarse a esta nueva nación? ¿o esta nueva nación llamada Argentina no incluye a las personas que vivieron en este continente antes de la llegada Europea del 1492 ? Las repuestas son ahora fáciles. No están incluidos en la nación los descendientes de los pueblos originarios. No dudo que el reconocimiento de las violaciones por parte de hombres europeos a mujeres indias ha marcado nuestra historia. Y probablemente haya borrado la historia de aquellas mujeres sobrevivientes obligándolas a adaptarse a una nueva situación. Pero esto aun no es público. O popular.

No son hegemónicos los rasgos que denoten descendencia asiática, africana ni indio americana. Los cuerpos femeninos usados por la televisión abierta argentina en la franja de 
14 a 16 horas durante los días de semana son blancos y europeos, tanto los que transitan ocasionalmente como los que trabajan diariamente en ese lugar.

\section{Las edades}

\begin{tabular}{|c|c|c|c|c|c|c|c|}
\hline canal & & & & MERICA & & 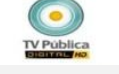 & \\
\hline \multirow[t]{5}{*}{ edades } & $15-20$ & $8.1 \%$ & $0 \%$ & $2 \%$ & $1.4 \%$ & $7.3 \%$ & $3.7 \%$ \\
\hline & $20-30$ & $40.9 \%$ & $71.6 \%$ & $44.6 \%$ & $56.3 \%$ & $58.8 \%$ & $54,4 \%$ \\
\hline & $31-40$ & $16.3 \%$ & $16.9 \%$ & $25 \%$ & $14 \%$ & $19.5 \%$ & $18,3 \%$ \\
\hline & $41-50$ & $14.7 \%$ & $1.8 \%$ & $14 \%$ & $8.4 \%$ & $4.8 \%$ & $8,7 \%$ \\
\hline & + de 51 & $19.6 \%$ & $9.4 \%$ & $12 \%$ & $19.7 \%$ & $9.7 \%$ & $14 \%$ \\
\hline
\end{tabular}

La mayoría de las mujeres quedan entre los 20 y 30 años. El $72.7 \%$ tienen menos de 40 años. La franja que va entre los 41 y los 50 parece ser la de la vergüenza, pocas confiesan transitar esa etapa hasta después de los 51 años donde ya quedan mujeres muy conocidas por la audiencia que por lo cual no pueden negar su edad o al menos descontarse mas de 10 años.. El promedio asciende al $14 \%$ por: en la telenovela hay dos protagonistas de más 50 ; en Telefe hay una panelista y las mujeres "muy conocidas" son entrevistadas casi a diario en los programas de chimentos.

Con respecto a las mujeres que trabajan diariamente ellas se ubicaban entre los 31 y los 40 o sea que se podría pensar que los cuerpos que transitan por la pantalla son más jóvenes en promedio que los que trabajan en ella.

En esta dimensión no se detectan diferencias sustanciales en el canal 9 (telenovela mexicana) y los demás canales ya que sus porcentajes son parecidos a canal América o Telefe. La existencias de arrugas, líneas gestuales, variación en los tonos de piel, bolsas, patas de gallo o cualquier signo del tiempo o de vida en el rostro de estas mujeres no es visible. Sus caras intentan, con mayor o menor éxito, ser como lienzos sin registro del tiempo, lisas parecen no tener relieve y los gestos quedan acotados generalmente a los ojos. Por lo tanto es lógico suponer que esta ausencia de signos debe deberse a un pesado 
maquillaje y/o a intervenciones invasivas en el rostro que en definitiva vienen a decir que siempre es mejor ser joven o lo más joven que uno pueda.

Hasta acá hay una preeminencia de cuerpos con estereotipo europeas, blancas y jóvenes.

Se toman ahora tres dimensiones en las cuales la intervención sobre el cuerpo puede ser una posibilidad muy simple, como las dietas alimenticias, los entrenamientos y las cirugías de pechos tan populares en nuestro país.

\begin{tabular}{|c|c|c|c|c|c|c|c|}
\hline canal & & canalnueve & & & & 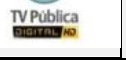 & \\
\hline \multirow[t]{4}{*}{$\begin{array}{l}\text { peso } \\
\text { corp }\end{array}$} & $\begin{array}{l}\text { delgadez } \\
\text { extrema }\end{array}$ & $9.8 \%$ & $66 \%$ & $6.3 \%$ & $43.6 \%$ & $26.8 \%$ & $30,5 \%$ \\
\hline & delgada & $59 \%$ & $30 \%$ & $46.8 \%$ & $21.1 \%$ & $26.8 \%$ & $36,7 \%$ \\
\hline & media & $16.3 \%$ & $0 \%$ & $34 \%$ & $7 \%$ & $41.4 \%$ & $19,7 \%$ \\
\hline & gruesa & $14.7 \%$ & $3.7 \%$ & $12.7 \%$ & $28.1 \%$ & $4.8 \%$ & 12,8 \\
\hline \multirow[t]{3}{*}{$\begin{array}{l}\text { tamaño } \\
\text { Pecho }\end{array}$} & grande & $59 \%$ & $84.9 \%$ & $48.9 \%$ & $90.1 \%$ & $46.3 \%$ & 65,8 \\
\hline & medio & $18 \%$ & $15 \%$ & $17 \%$ & $8.4 \%$ & $43.9 \%$ & 20,4 \\
\hline & chico & $22.9 \%$ & $0 \%$ & $42 \%$ & $1.4 \%$ & $9.75 \%$ & 15,2 \\
\hline \multirow[t]{3}{*}{$\begin{array}{l}\text { tono } \\
\text { muscular }\end{array}$} & débil & $22.9 \%$ & $35.8 \%$ & $57.4 \%$ & $35.2 \%$ & $51.2 \%$ & 40,5 \\
\hline & medio & $52.4 \%$ & $26.4 \%$ & $31.9 \%$ & $49.2 \%$ & $43.9 \%$ & 40,7 \\
\hline & fuerte & $24.5 \%$ & $37.7 \%$ & $10.6 \%$ & $15.4 \%$ & $4.8 \%$ & 18,6 \\
\hline
\end{tabular}

\section{El Peso}

En esta dimensión el $67 \%$ de los cuerpos que se observan son delgados o con extrema delgadez y dentro de esto el porcentaje de delgadez extrema es realmente muy alto sobretodo sabiendo que este indicador está muy cercano o dentro de los desordenes alimentarios que en la actualidad tienen gran incidencia entre las mujeres. 

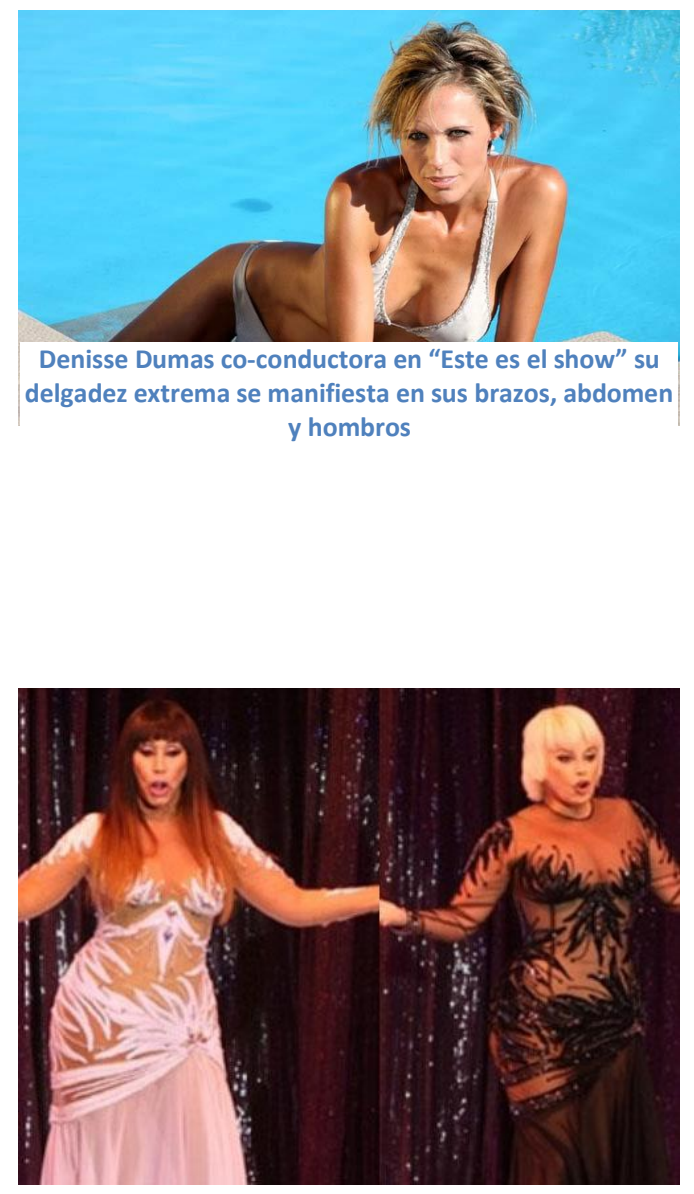

Moria Casan y Carmen Barbieri, mujeres de peso grueso y de mas de $\mathbf{5 0}$ años
Según ALUBA (Asociación de lucha contra la Bulimia y la Anorexia) uno de cada 25 jóvenes argentinos padece de bulimia y/o anorexia; cuestión que en la época estival se agudiza al aumentar las consultas y los jóvenes en tratamiento incrementan sus síntomas.

Notamos que el $12 \%$ que participa del indicador grueso tiene relación con el indicador de más de 50 en la edad. Recordamos ejemplos que pueden ilustrar esta relación: Carmen Barbieri, Moria Casan, Laura Ufbal.

El canal 13 y la TV pública, que son los canales con mayor y menor audiencia de esta franja horaria son quienes muestran menor porcentaje de personas de peso grueso. Este porcentaje equivale a decir que en 10 emisiones hubo en 2 una mujer que entrara al indicador gruesa. Y en los casos de mayor porcentaje significa sobre 10 emisiones en 4 aparece 1 mujer de peso grueso.

Si analizamos de la misma manera el indicador delgadez extrema tendríamos: que el canal 13 que es el de mayor audiencia, tiene todos los días más de una mujer con ese indicador en la pantalla; que tanto en la telenovela mexicana como en América ninguna de sus protagonistas principales ni que trabajan diariamente lo son, lo cual baja el porcentaje de delgadez extrema; que la gran mayoría de las mujeres con delgadez extrema está entre los índices de 20/31 años.

La pregunta es ¿Por qué hay que ser tan delgada? ¿Delgadez es un símbolo, una performance, de qué? Es evidente que la delgadez es un valor en nuestras pantallas pero no 
se alzan voces en torno al exceso de esto, se nota que esto deja de ser percibido y se torna moda. Este delgadísimo cuerpo parece pasar de ser un deseo a una obligación, una obsesión. Una obsesión dentro de esta clase social que domina la tv. Clases o categorías sociales para quienes los valores del cuerpo pasan por la estética.

\section{Los pechos}

La grilla es tajante el 65, 8\% de los cuerpos tienen senos grandes, los canales de mayor audiencia tienen el porcentaje más alto. Concluimos que la TV elige mujeres con pechos grandes. Y las mujeres intervienen en este sentido su cuerpo para pertenecer a este medio. Intervenciones quirúrgicas que modifican la imagen corporal de estas mujeres. Violentamente modificada, una prótesis se incorpora al sujeto cambiando la topología del cuerpo, de su cuerpo, un cuerpo que tendrá que volver a construirse desde este volumen que se instala en su pecho, adelante del corazón, justo debajo del rostro. ¿Qué sensaciones nuevas tendrá?

Las modificaciones corporales son muy antiguas entre los humanos y se han hecho en distintas partes del cuerpo con diferentes significados. Agrandarse orejas, labios, tatuarse, colocarse anillos son prácticas con significados religiosos, sociales o políticos. Este agrandamiento de los pechos en las mujeres tiene un significado no expresado públicamente pero todo hace suponer que refiere abiertamente al erotismo femenino relacionando los pechos con la disponibilidad sexual de estas mujeres. No es expresado públicamente porque atraviesa algunos puntos éticos y legales que se suponen no correctos en nuestra sociedad actual. Que alguien no acceda a un puesto de trabajo o no mejore su condición laboral porque una parte de su cuerpo no está en concordancia con el deseo del empleador, podría ser delito. Canales privados pero también el público, que casualmente, contrata a una conductora famosa por el tamaño de sus pechos.

Se hace evidente que para las mujeres que transitan la TV esta parte del cuerpo debe tener una sola estética: rígidos, redondos y grandes. Parece depender de que lugares tenga o quiera ocupar, más grande serán los pechos y el escote. Aun cuando el rol femenino sea el de periodista en los noticieros, donde solo interviene leyendo las noticias, se ven también 
estas modificaciones, por lo tanto ¿comienza esto a ser una condición para acceder a puestos de trabajo en la TV? Se buscó la respuesta en el INADI. Según la abogada Tatiana Hirschhorn de la Coordinación de Observatorios de la discriminación en radio y televisión ${ }^{15}$ existe una naturalización de la acción de aumentar el volumen de los pechos de las mujeres que se mueven o trabajan en el medio. Pero no hay denuncias radicadas de esta índole, en cambio si las hay por la imagen que se difunde de los CF en la tv. Nos indican que el promedio de las mujeres que se someten a cirugías plásticas es de 25 años y según la Asociación Argentina de Cirugía Plástica, Estética y Reparadora (SACPER) aparece una adicción a las cirugías estéticas sobre todo entre mujeres que van desde los 40 a los 60 años.

Los pechos han sido a lo largo del tiempo símbolos de femineidad, de sensualidad, de maternidad y en la actualidad parecen carteles que hablan de la disponibilidad sexual de la mujer. Para estar en las pantallas de TV hay que estar, al parecer, muy disponible. Estos nuevos pechos no reciben el impacto de los años, no se debilitaran como músculos por lo tanto tendremos mujeres de 60 años con pechos de una joven de 20 años ¿serán nuevos cuerpos? o se someterán a nuevas cirugías para adapten esos pechos a su edad. Hemos llegado al punto de una dependencia que se establece con la cirugía, la mujer intervenida queda atada a nuevas cirugías que corrijan y repongan estos nuevos pechos. De esta manera y como la mayoría de los cirujanos estéticos son hombres quedan atadas a nuevos hombres que tallaran nuevas formas en su cuerpo. Y esta dependencia puede llegar a la adicción.

La gran mayoría de mujeres en la actualidad se medicaliza por estética, para trabajar en los medios de comunicación. Estos nuevos pechos traen:

1. una simbología de la disponibilidad sexual femenina

2. una mayor dependencia hacia la medicina, medicalización (dependencia de un medico generalmente varón)

3. la necesidad de una disponibilidad de dinero que invertir en estas cuestiones.

\footnotetext{
${ }^{15}$ entrevista realizada a la abogada Tatiana Hirschhorn, de la Coordinación de Observatorios de la Discriminación - INADI
} 


\section{El tono muscular}

Esta dimensión está en función de intentar relacionar estos cuerpos con la actividad física y el movimiento. Como vemos es negativo. Por lo tanto el peso y las formas del cuerpo son logrados a partir de rigurosas dietas, cirugías o métodos estéticos como camas solares, meso lifting, radio frecuencia, drenaje linfático, electro estimulación y etc. Esto promueve al cuerpo femenino como una mercancía a redefinir, a modificar, a normalizar. Y otra vez surge el tema económico, hay una inversión económica en todas estas actividades para mantenerse dentro de los cánones de belleza establecidos llevando al CF a ser objeto de comercializaciones.

Muchos cuerpos son intervenidos, producen nuevas identidades, se incluyen en lo bello y principalmente en lo hegemónico. Un solo tipo de cuerpo deja ver la televisión argentina en esta franja horaria. 
A continuación se analizan que partes del cuerpo son las más visibles y en función de eso vemos algunas particularidades del rostro de las mujeres.

\begin{tabular}{|c|c|c|c|c|c|c|c|}
\hline canales & & (9) & & & 000 & (1) & porcentajes \\
\hline \multirow[t]{3}{*}{$\begin{array}{c}\text { Partes } \\
\text { visibles }\end{array}$} & cara & $100 \%$ & $100 \%$ & $100 \%$ & $100 \%$ & $100 \%$ & $100 \%$ \\
\hline & pechos & $8.1 \%$ & $35.8 \%$ & $59.5 \%$ & $49.2 \%$ & $4.8 \%$ & $31.4 \%$ \\
\hline & piernas & $8.1 \%$ & $41.5 \%$ & $57.4 \%$ & $14 \%$ & $14.6 \%$ & $27.1 \%$ \\
\hline \multirow[t]{2}{*}{$\begin{array}{c}\text { Cabello. } \\
\text { Tipo }\end{array}$} & lacio & $98.3 \%$ & $98.1 \%$ & $97 \%$ & $100 \%$ & $100 \%$ & $98.6 \%$ \\
\hline & rulos & $1.6 \%$ & $1.8 \%$ & $2 \%$ & $0 \%$ & $5 \%$ & $2 \%$ \\
\hline \multirow[t]{3}{*}{$\begin{array}{c}\text { Cabello. } \\
\text { Color } \\
\end{array}$} & rubio & $19.6 \%$ & $62.2 \%$ & $63 \%$ & $63.3 \%$ & $31 \%$ & $47.8 \%$ \\
\hline & castaño & $80.3 \%$ & $32 \%$ & $36 \%$ & $35.2 \%$ & $68.2 \%$ & 50.3 \\
\hline & rojo & $0 \%$ & $5.6 \%$ & $0 \%$ & $1.4 \%$ & $0 \%$ & $1.4 \%$ \\
\hline \multirow[t]{2}{*}{$\begin{array}{l}\text { Cabello. } \\
\text { Peinado }\end{array}$} & suelto & $77 \%$ & $81.1 \%$ & $85 \%$ & $88.7 \%$ & $73.1 \%$ & $80.8 \%$ \\
\hline & atado & $22.9 \%$ & $18.8 \%$ & $14 \%$ & $11.2 \%$ & $26.8 \%$ & $18.7 \%$ \\
\hline \multirow[t]{3}{*}{ maquillaje } & pesado & $72.1 \%$ & $96.2 \%$ & $74.4 \%$ & $76 \%$ & $36.5 \%$ & $71 \%$ \\
\hline & medio & $22.9 \%$ & $0 \%$ & $25.5 \%$ & $19.7 \%$ & $29.2 \%$ & $19.4 \%$ \\
\hline & liviano & $4.9 \%$ & $3.7 \%$ & $0 \%$ & $4.2 \%$ & $34.1 \%$ & 9.3 \\
\hline
\end{tabular}

\section{Partes del cuerpo más visibles}

La cara es la parte más visible en todos los canales tiene el mayor privilegio, siempre es visible con una alta cantidad de tiempo de exposición. El rostro, la mirada, los labios son la referencia para saber del sujeto, para enterarnos de cómo esta, que siente. El puente que nos lleva al sujeto sin un privilegio de ninguna de sus partes sino en un todo. Las cámaras de tv intentan tomar esos rostros en sus posturas más naturales, en sus reacciones primeras, sorprender al rostro antes que anteponga una pose, en un juego con las cámaras los otros intentan ocultar o mostrar sentimientos que la cámara tratara de desenmascarar. 


\section{El Maquillaje (Make up)}

Puede ser liviano como esfumado con tonos que se asemejan al tono de piel de la mujer, con labios en tonos naturales sin gloss ni delineador que parece fundirse con la cara para darle protagonismo a la blancura de los dientes. En bocas siempre semi abiertas los dientes brillan en un gesto sensual. Y también el make up puede ser pesado generalmente es sobre los ojos donde los parpados se convierten en una paleta de tonos y delineadores. En este punto las mexicanas introducen una diferencia: el make up es televisivo, combina los colores de la ropa con la sombra de los ojos, por ejemplo. Y las bocas están definidas y pintadas en colores plenos (rojo). Un maquillaje mucho más tradicional que el argentino.

En cuestión de escotes y de polleras hay diferencias. En los canales de mayor audiencia, 13 y Telefe, la piel se hace visible a través de la ropa dando una sensación de seda, de luz, de brillo, de suavidad. Una visibilidad pensada en clave de seducción que en algunas, generalmente las más jóvenes, adopta un look urbano algo relajado y casual, que no abandona los escotes pronunciados pero con tacos bajos o zapatillas, remeras que se caen hacia los costados mostrando un hombro, detalles de bijouterie étnica. Y en las coconductoras o invitadas de más edad un look de coctel con más strapless, detalles que inspiran corsetería y algunos brillos. Siempre piel en la parte superior del torso. Lo étnico para lo más informal, la bijou de brillo para el estilo coctel pero ambos en tamaños grandes y siempre mucha seducción.

En el canal público su conductora hace un giro en las partes visibles, casi no usa escotes, muy pocas veces muestra su piel, usa telas de algodón, viste jeans o vestidos de look urbano y muy pocos adheridos al cuerpo. Ella podría estar vestida como cualquier chica en la calle. La diferencia es que no hay seducción, al menos dirigida, en su look. Fresca y natural, eso parece intentar.

La telenovela mexica introduce la tercera diferencia. En estos CF las partes visibles son realmente pocas. El vestuario es ostentoso, sobrecargado, las prendas son muy elaboradas tienen variedad de texturas y vienen a demostrar o acompañar la clase social de cada personaje. Formalidad en la ropa y sus colores acompañada de joyas y no de bijouterie para 
las mujeres dominantes. Tonos de blancos, nada ceñido al cuerpo y sin adornos para la inocente y joven protagonista y para las mujeres de "moral ligera" colores plenos, ropa adherida y piel en los escotes. Es notorio como la ropa acompaña las clases sociales en este caso.

En las argentinas de más de 50, que son todas muy conocidas, notamos que la visibilidad de la piel es muy alta: hombros, pechos, brazos, piernas, cara, manos. Y el look es siempre de noche con ropa de diseño con lo cual son en sí mismas una escenografía. El vestido es mostrado en toda su amplitud lo que influye en sus movimientos, en como se sientan, en como caminan. Siempre seductoras sus cuerpos se funden con el vestuario en una producción de si mismas como un personaje mediático.

\section{Cabello}

Que en la televisión las mujeres tienen el cabello lacio podría afirmarse dejando de lado a un grupo absolutamente minoritario. Sobretodo en el canal América los cabellos lacios, teñidos de rubio y con extensiones son tan predominantes que parecen una publicidad de peluquerías. En los demás canales hay alguna variedad de tonos, el colorado es muy poco usual, los castaños se presentan como mayoría en la telenovela mexicana y en el canal estatal. Y en los canales de gran audiencia argentina la mayoría amplia es rubia. Mayoritariamente el cabello de estas mujeres tiene lo que se llama "cortina" un postizo en la parte de atrás que da volumen a toda la cabellera.

Los peinados en las argentinas son extraños la mayoría llevan el cabello suelto y natural, con un look despeinado. En cambio en las mexicanas los cabellos tienen peinados rígidos, altos, recogidos trabajos con spray.

Rubias, jóvenes, delgadas, pechugonas, blancas, con mucha piel y mucho maquillaje podríamos pensar en el $80 \%$ de quienes trabajan en la tv y no distinguir ninguna de ellas. Lo que vemos en el CF es tan mayoritario, tan homogéneo que disminuye las diferencias hasta volverlas muy sutiles. Sutiles tonos de rubios, de blancos, de lacios, de volúmenes...

Pero la tv también es parlante ¿Cómo participan oralmente estos CF? 


\begin{tabular}{|c|c|c|c|c|c|c|c|}
\hline canales & & (9analnueve & canaltrece & AMERICA & 000 & 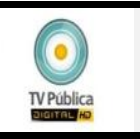 & porcentajes \\
\hline \multirow{3}{*}{ habla } & mucho & $11.4 \%$ & $22.6 \%$ & $29.7 \%$ & $30.9 \%$ & $12.1 \%$ & $21,3 \%$ \\
\hline & medio & $39.3 \%$ & $20.7 \%$ & $21.2 \%$ & $23,9 \%$ & $43,9 \%$ & $34,8 \%$ \\
\hline & poco & $49.1 \%$ & $56.6 \%$ & $23.4 \%$ & $45 \%$ & $43,9 \%$ & $43,6 \%$ \\
\hline & & & & & & & \\
\hline \multirow[t]{3}{*}{ voz } & alta & $26.2 \%$ & $47.1 \%$ & $36.1 \%$ & $39.4 \%$ & $17 \%$ & $33,1 \%$ \\
\hline & moderada & $42.6 \%$ & $18.8 \%$ & $34 \%$ & $28.1 \%$ & $39 \%$ & $32,5 \%$ \\
\hline & baja & $27.8 \%$ & $33.9 \%$ & $25.5 \%$ & $32.3 \%$ & $43.9 \%$ & $32.6 \%$ \\
\hline
\end{tabular}

En que tono de voz y cuánto hablan es la pregunta de esta parte de la grilla y la observación muestra que los porcentajes son bajos. La participación oral es en relación con los demás participantes de los programas (los hombres) pequeña, solo en un $21 \%$ podríamos decir que participan activamente o mucho. El dato más curioso aparece en la telenovela, con un alto porcentajes de personajes femeninos, su participación oral es pequeña. Lo que señala que desde los guiones la oralidad de las mujeres es reducida. Se podría decir que la mitad de las mujeres se expresa poco oralmente en la tv. Probablemente esto tenga relación con la participación de ellas como personajes secundarios, al desarrollarse siempre en las periferias de los programas su participación resulta escasa en lo oral, no así en lo visual. Los hombres son menos cantidad pero en roles protagónicos por lo tanto su participación oral es alta.

En los tonos de voz no se detectaron grandes diferencias. 
Y la última parte de la grilla ¿Y en que roles hablan y se mueven?

\begin{tabular}{|c|c|c|c|c|c|c|c|}
\hline & & 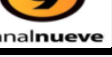 & - & AMERICA & & 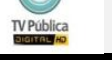 & totales \\
\hline \multirow[t]{13}{*}{ roles } & interroga & $0 \%$ & $32 \%$ & $27.6 \%$ & $18.3 \%$ & $39 \%$ & $23,3 \%$ \\
\hline & explica & $14.7 \%$ & $45.2 \%$ & $59.9 \%$ & $40.8 \%$ & $34.1 \%$ & $38,9 \%$ \\
\hline & lidera & $26.2 \%$ & $11.3 \%$ & $4.2 \%$ & $12.6 \%$ & $2.4 \%$ & $11,3 \%$ \\
\hline & ordena & $21.3 \%$ & $0 \%$ & $4.2 \%$ & $8.4 \%$ & $0 \%$ & $6,7 \%$ \\
\hline & obedece & $24.5 \%$ & $0 \%$ & $0 \%$ & $1.4 \%$ & $0 \%$ & $5,8 \%$ \\
\hline & enseña & $1.6 \%$ & $0 \%$ & $2.1 \%$ & $2.8 \%$ & $17 \%$ & $4,7 \%$ \\
\hline & aprende & $0 \%$ & $0 \%$ & $0 \%$ & $0 \%$ & $14.6 \%$ & $2,9 \%$ \\
\hline & suj erótico & $34.4 \%$ & $54.7 \%$ & $29.7 \%$ & $63.3 \%$ & $4.8 \%$ & $37,3 \%$ \\
\hline & profesional & $47.5 \%$ & $62.2 \%$ & $76.5 \%$ & $56.3 \%$ & $75.6 \%$ & $63,6 \%$ \\
\hline & universitarias & $0 \%$ & $0 \%$ & $2 \%$ & $1.4 \%$ & $7.3 \%$ & $2,1 \%$ \\
\hline & trabaj rentado & $68.8 \%$ & $75.4 \%$ & $97.8 \%$ & $76 \%$ & $82.9 \%$ & $80,1 \%$ \\
\hline & vende placer & 0 & $32 \%$ & $12.7 \%$ & $28.1 \%$ & $4.8 \%$ & $15,5 \%$ \\
\hline & vende objetos & 0 & $0 \%$ & $4.2 \%$ & $7 \%$ & $9.75 \%$ & $4,1 \%$ \\
\hline
\end{tabular}

Tomando las definiciones operativas que tengan más de un $50 \%$ se puede decir que los CF aparecen en roles profesionales no universitarios (periodistas, artistas, vedette, conductoras, cantantes y bailarinas) en un $63 \%$ y con trabajos rentados. Prácticamente no hay roles de enseñanza ni de aprendizaje ni de obediencia. No venden objetos en los programas. Y las mujeres que participan en un $80 \%$ tienen trabajos rentados. Se detecta un cambio importante de aquella televisión de la década del 70 y 80 donde en programas, que iban en este horario, las mujeres enseñaban a cocinar, coser, hacer bricolaje, maquillaje y demás actividades, esto casi ha desaparecido de la tv abierta. Las únicas mujeres en roles de liderazgo son los personajes de la telenovela mexicana. En el rol de interrogar y el de explicar hay un $62,2 \%$ que sacando la telenovela daría un $74 \%$, por lo tanto los $\mathrm{CF}$ aparecen mayoritariamente explicando, preguntando, relatando y comentando chimentos. Y si no en algún rol superfluo.

En los canales de mayor audiencia hay en roles de sujetos eróticos un porcentaje muy alto que no se refleja al total ya que en el canal estatal donde son casi nulas. Estas mujeres son muy conocidas por todos los televidentes y generan un negocio de publicidades en torno a ellas. 
Para visualizar que mercantilización utiliza el CF en la televisión he armado una grilla que registra solamente las publicidades de los programas observados.

Se hace una lectura total de todos los canales sin importar que tipo de programa corresponda a ese horario.

Se encuentran 875 publicidades, en las cuales en un $40 \%$ el protagonismo es de una mujer y en el $60 \%$ restante se divide entre hombres, imágenes puras y niños. En una primera conclusión se utilizan más mujeres como protagonistas que hombres o imágenes simples.

De estas mujeres se buscan sus estereotipos, el rol ocupacional: profesionales ó amas de casa o no demuestran ninguna ocupación. Y las edades que aparentan las protagonistas.

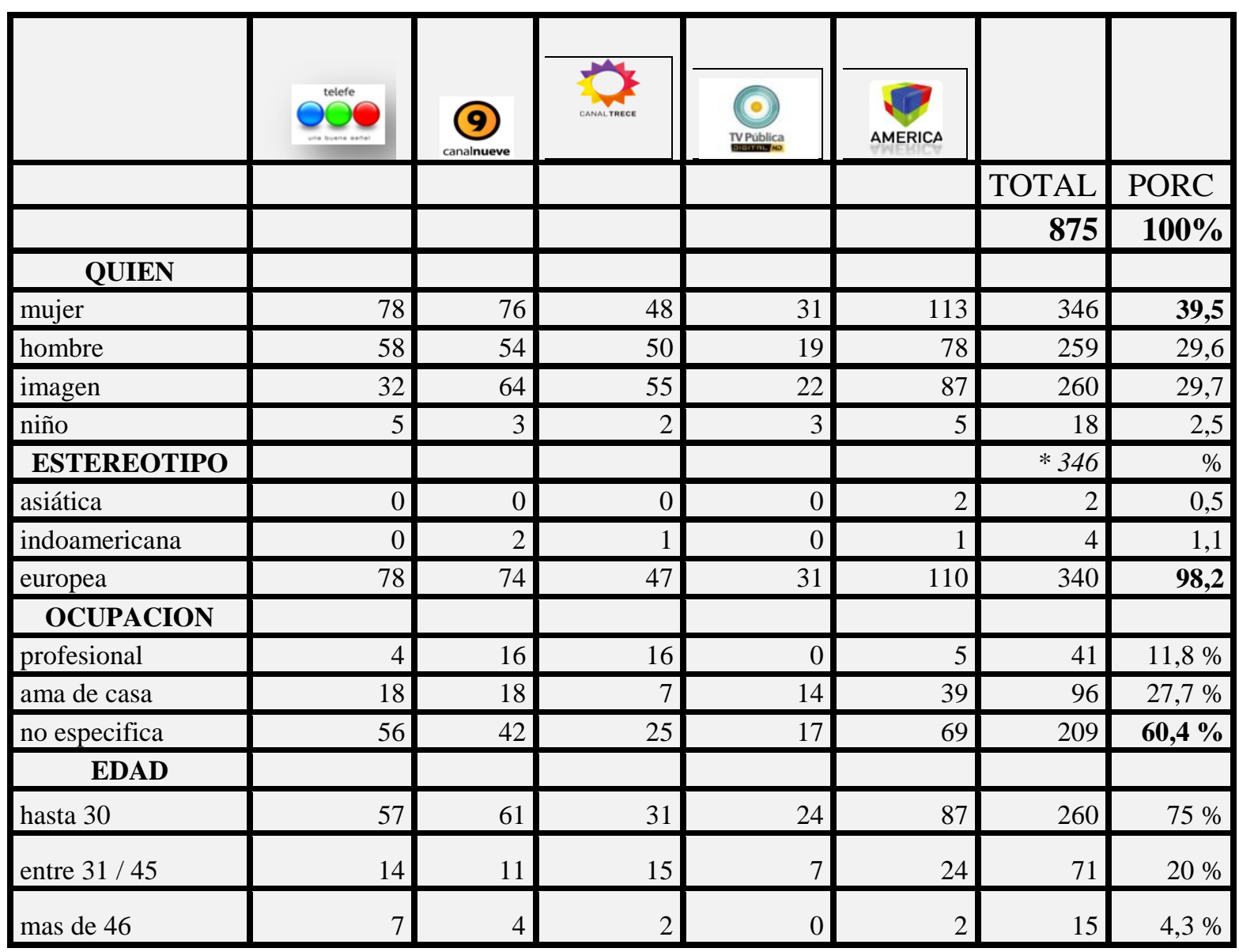

- $\quad 346$ total publicidades con mujeres protagonista 
La grilla nos marca cuerpos femeninos de menos de 30 años, sin ocupaciones y de estereotipo europeo. Aquí es claro que tener más de 45 es casi no participar en este tipo de cuestiones.

Otra vez un único estereotipo de mujer blanca europea pero unido totalmente a la juventud. No importa en que rol se coloca a la mujer en la publicidad siempre es joven, aunque la imagen sea de madre esta nunca parece tener más de 30 años.

La blancura en la piel y la juventud parecen ser una virtud ineludible para los publicistas. Ni siquiera hay mujeres bronceadas por el sol. Siempre la piel es blanca

Llama la atención en la definición de ocupación como en la mayoría no se demuestra "el hacer" de las mujeres.

En la realidad las mujeres se dividen entre las que trabajan fuera de su hogar y las que no lo hacen. Estas últimas catalogadas como amas de casas, tienen un disvalor para el grupo que si lo hace. Asimismo quienes trabajan fuera del hogar son las que ganan su propio dinero con lo cual la decisión de cómo gastarlo es más fácil que sea solo de ellas. Sin embargo se sabe que la mayoría de las mujeres, sino todas, realizan las tareas del hogar y la crianza de los niños. Por lo tanto el grupo a quien se dirigen las propagandas de artículos que se consuman diariamente o habitualmente dentro de una familia es a quienes decidan esas compran y son mujeres, sin importar su ocupación.

Pero tal vez aquellas mujeres que trabajan dentro y fuera del hogar, no se sientan identificadas en aquellas publicidades donde un ama de casa cuenta sus problemas. Y la mayoría de sus problemas son sobre como limpiar la casa hasta dejarla casi con la asepsia de un laboratorio. Por lo tanto, la mayoría de las publicidades no identifica a la mujer en una ocupación u otra, lo que trae otra consecuencia a nivel de la imagen de estos CF. La imagen de las mujeres en su hacer queda como flotando en la nada, compran, curan niños, comen chocolates, consumen bebidas light, cuidan su cuerpo para estar bellas y lavan ropa, son expertas en esa actividad. Entonces al igual que en los programas la vuelta sobre estas ocupaciones femeninas aparecen superfluas porque poner una curita a un niño no es curarlo 
y limpiar con desinfectantes no ser una bioquímica. Entonces con el fin de mostrar y convencernos sobre las virtudes de un producto los CF quedan, otra vez, supeditados a actividades livianas, sin jerarquía.

Avanzando en las observaciones he catalogado que partes del CF se hacen más visibles en las publicidades y si esto hace una referencia erótica.

\begin{tabular}{|c|c|c|c|c|c|c|c|}
\hline & & $\underset{\text { canalnueve }}{(9)}$ & & (1) & & & \\
\hline & & & & & & Total & Porcentaje \\
\hline & & & & & & $* 346$ & $100 \%$ \\
\hline & & & & & & & \\
\hline cara & 65 & 67 & 45 & 30 & 91 & 298 & $86 \%$ \\
\hline cadera & 5 & 17 & 3 & 1 & 10 & 36 & $10,4 \%$ \\
\hline pecho & 8 & 16 & 6 & 6 & 23 & 59 & $17 \%$ \\
\hline manos & 1 & 2 & 0 & 1 & 23 & 26 & $7,5 \%$ \\
\hline baila & 5 & 10 & 1 & 0 & 9 & 25 & $7,2 \%$ \\
\hline Ref. sexual. & 21 & 14 & 6 & 9 & 24 & 74 & $21,3 \%$ \\
\hline
\end{tabular}

*Sobre total de 346 publicidades donde la protagonista es mujer

Según esto el CF se muestra sobre todo como un rostro y en un porcentaje más bajo la parte que mas prevalece en imagen son los pechos, luego las caderas y por último las manos. Pero mostrar a alguien sin verle la cara es casi imposible en nuestra sociedad entonces si se deja esto de lado la parte que mas prevalece en las publicidades es el pecho, luego las caderas y por último las manos.

La referencia sexual en las publicidades es cuando los CF hacen un gesto, un símbolo de erotismo en su expresión como por ejemplo una boca entreabierta comiendo un chocolate, una pareja en sus preliminares amorosos, aquellas viejas publicidades de jean donde ellas se vestían en un ascensor. El porcentaje de erotismo fue bajo en este horario.

También fue bajo el movimiento de los CF en las publicidades, tan bajo que no fue valido colocarlo. Solo en una publicidad la protagonista bailaba mostrando sus brillosas piernas, al parecer el movimiento del CF no es una cualidad que sirva para vender. Las mujeres en las 
publicidades no bailan, ni corren, ni saltan, ni cantan. No hubo publicidades de ropa deportiva.

En conclusión no se utiliza un CF erótico para las ventas de este horario que coincide con una mayoría de televidentes mujeres. Y si se utiliza un CF pasivo y dependiente ya que no demuestra ganar su propio dinero ni tener la suficiente inteligencia o fuerza para realizar y solucionar problemas.

La siguiente pregunta es ¿Quién vende en estas publicidades?

Y en este punto paso algo muy extraño: en las publicidades protagonizadas por mujeres mayoritariamente se oye una voz en off que es masculina explicando y/o aconsejando sobre el producto y su uso. Entonces de las 875 publicidades en 648 interviene una voz masculina (74\%) y en 241 hay voz femenina $(27,5 \%)$ con lo que se nota que en algunas intervienen ambos pero sino es mayoritaria la voz masculina hablándole a una supuesta consumidora. La voz masculina explica el producto, cuenta su uso, aconseja sobre los temas que al parecer solo importan a las mujeres. Hasta puede ser un personaje de historieta (un dibujo animado) cuyos dichos serán muy importantes para la mujer.

Las voces y protagonistas femeninas hablan en $1^{\circ}$ persona del singular o del plural. Las voces masculinas hablan en $3^{\circ}$ del singular o plural.

\begin{tabular}{|c|c|c|c|c|c|c|c|}
\hline VOZ MASCULINA & & & & & & 648 & $74 \%$ \\
\hline VOZ FEMENINA & 46 & 61 & 57 & 16 & 61 & 241 & $27,5 \%$ \\
\hline $\begin{array}{c}\text { TOTAL } \\
\text { PUBLICIDADES. }\end{array}$ & 00 & (9) & & (6) & & 875 & \\
\hline
\end{tabular}


¿Qué se vende con estas publicidades?

Para responder esta pregunta he separado las publicidades según los productos publicitados fueran:

- bienes durables:

A electrodomésticos/

- bienes no durables:

$\mathrm{B}$ alimentos / C artículos de belleza / D artículos de limpieza / $\mathrm{E}$ bebidas con alcohol / $\mathrm{F}$ artículos de fotografía / G golosinas / H cigarrillos / I jugos / J aguas / K artículos de higiene personal / L indumentaria / LL muebles y decoración / M productos para bebes / N productos para mascotas / $\tilde{\mathrm{N}}$ gaseosas / O supermercados / P productos de salud.

- Servicios:

q. empresas que brindan servicios (ejemplos: telecentro, fibertal, movistar) /

r. productos financieros (tarjetas de créditos) / t. viajes y recreación /

u. institucionales del canal / v. campañas sociales del gobierno / w. juegos de azar

\begin{tabular}{|c|c|c|c|c|c|c|c|c|c|c|c|c|c|c|c|c|c|c|c|c|c|c|c|c|c|c|}
\hline CANALES & total pub & A & $B$ & $c$ & 0 & $\mathrm{E}$ & $\mathrm{F}$ & $G$ & H & I & 1 & K & l & แ. & M & N & $\tilde{N}$ & 0 & $p$ & $q$ & 1 & $s$ & $t$ & $u$ & $v$ & W \\
\hline TillfFE & 183 & 11. & 18 & 9 & 11 & 0 & 0 & 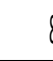 & ( & & 5 & 11. & & 0 & 3 & 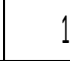 & 8 & 8 & 7 & 11 & 0 & 0 & 14 & 39 & 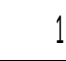 & \\
\hline 9 & 193 & & 27 & 29 & 5 & 0 & 0 & 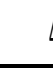 & 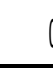 & & 2 & 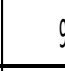 & & 2 & 2 & 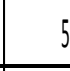 & 1 & 20 & 18 & 25 & 8 & 0 & 1 & 18 & 0 & 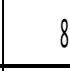 \\
\hline 13 & 174 & & 18 & 13 & 3 & 0 & 0 & & 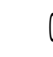 & & 2 & & & 2 & 2 & 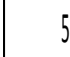 & 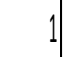 & 9 & 13 & 15 & 0 & 0 & 26 & 35 & 1 & 1 \\
\hline IPUBILA & 71 & & 10 & 1 & 6 & 0 & 0 & 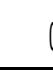 & 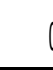 & & 1 & 10 & & 0 & 0 & 0 & 0 & $d$ & 3 & & 1 & 6 & 2 & 22 & 1 & 1 \\
\hline AMERCA & 254 & 24 & 42 & 34 & 25 & 5 & 0 & 1 & ( & 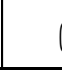 & 0 & 31 & & 3 & 0 & 3 & 0 & 16 & 33 & & 1 & 2 & 11 & 21 & 1 & 1 \\
\hline TOTAL & 875 & 39 & 115 & 86 & 50 & 4 & 0 & 28 & I & 1 & 10 & 70 & & 1 & 1 & 14 & 10 & 53 & 74 & 56 & 10 & 8 & 54 & 135 & & 4 \\
\hline$\%$ & & 4,2 & 13 & 9,5 & 5,5 & 0,4 & 0 & 3 & & -1 & 1,1 & 7,8 & & 70,3 & 0,7 & 1,5 & 1,1 & 5,9 & 8,3 & 6,2 & 1,1 & 0,8 & 6 & 15 & 0,4 & \\
\hline
\end{tabular}


Grilla de observación de publicidades:

Se trabaja sobre los porcentajes que dieron las 875 publicidades observadas.

De mayor a menor las que más se ven son:

\begin{tabular}{|c|c|c|}
\hline Codigo & Tipo de publicidad & Porcentaje \\
\hline $\mathrm{u}$ & INSTITUCIONALES & 15 \\
\hline $\mathrm{B}$ & ALIMENTOS & 12,8 \\
\hline $\mathrm{C}$ & BELLEZA & 9,5 \\
\hline $\mathrm{P}$ & SALUD & 8,3 \\
\hline $\mathrm{K}$ & HIGIENE PERSONAL & 7,8 \\
\hline $\mathrm{q}$ & EMPRESAS DE SERVICIOS & 6,2 \\
\hline $\mathrm{t}$ & VIAJES Y RECREACION & 6 \\
\hline $\mathrm{O}$ & SUPERMERCADOS & 5,9 \\
\hline $\mathrm{D}$ & ARTICULOS DE LIMPIEZA & 5,5 \\
\hline $\mathrm{A}$ & ELECTRODOMESTICOS & 4,2 \\
\hline $\mathrm{Z}$ & BEB. S/ALCOHOL & 3,6 \\
\hline $\mathrm{G}$ & GOLOSINAS & 3 \\
\hline $\mathrm{W}$ & JUEGOS DE AZAR & 2,9 \\
\hline$\tilde{N}$ & GASEOSAS & 1 \\
\hline $\mathrm{I}$ & JUGOS & 1,3 \\
\hline $\mathrm{J}$ & AGUAS & 1,1 \\
\hline $\mathrm{r}$ & PROD FINANCIEROS & 1,1 \\
\hline $\mathrm{N}$ & ARTIIULOS PARA & 1,5 \\
\hline $\mathrm{M}$ & ARTIICULOS PARA BEBES & 0,7 \\
\hline $\mathrm{LL}$ & MUEBLES Y DECORACION & 0,3 \\
\hline $\mathrm{E}$ & BEBIDAS CON ALCOHOL & 0,4 \\
\hline $\mathrm{F}$ & $\begin{array}{c}\text { ARTICULOS DE } \\
\text { FOTOGRAFIA }\end{array}$ & 0 \\
\hline $\mathrm{H}$ & CIGARRILLOS & 0 \\
\hline $\mathrm{S}$ & COMPANIAS DE SEGURO & 0,8 \\
\hline
\end{tabular}




\begin{tabular}{|c|c|c|}
\hline $\mathrm{V}$ & CAMPAÑAS DEL ESTADO & 0,4 \\
\hline $\mathrm{L}$ & INDUMENTARIA & 0,7 \\
\hline
\end{tabular}

Las bebidas sin alcohol quedaron agrupadas de la siguiente manera:

\begin{tabular}{|c|r|l|}
\hline gaseosas & 1 & \\
\hline jugos & 1,3 & \\
\hline aguas & 1,1 & \\
\hline total & $\mathbf{3 , 6}$ & bebidas sin alcohol \\
\hline
\end{tabular}

La mayor publicidad es la institucional, se venden primero los productos del canal, o sea, la televisión se vende así misma.

Luego los 3 productos que se publicitan más son: alimentos, artículos de belleza y productos de salud. Seguido muy de cerca por los productos de higiene personal, jabones, desodorantes, pastas de dientes. En un horario con mayor cantidad de mujeres televidentes la alimentación, la salud, la belleza y la higiene es lo que mas se intenta venderles o ellas son el nicho de compradoras de estos productos.

Le siguen con un porcentaje muy parejo los servicios, en su mayoría de telefonía, internet y televisión; los viajes y recreación, que son películas, lugares de vacaciones, obras de teatro; las cadenas de supermercado y los productos de limpieza.

Cuando se habla de viajes y recreación es notable como estos productos son para todos en general, parejas, familias, solteros/as, niños. En cambio los supermercados y productos de limpieza se dirigen solo a mujeres.

Las bebidas sin alcohol, los electrodomésticos, las golosinas y los juegos de azar están en porcentajes parecidos y muy debajo de la tabla. Y ya casi con muy pocas publicidades aparecen: productos financieros como bancos o tarjetas de crédito, artículos para bebes, para mascotas, muebles y decoración, bebidas con alcohol, seguros y campañas del estado. No se observaron publicidades de cigarrillos ni de fotos. 
La observación a través de la grilla me llevó por un largo camino con pocas diversidades. Un solo modelo estético hegemónico se encuentra en la televisión actual argentina. Este modelo de CF dominante es excluyente, no admite diversidades ni en los tonos, ni en las formas, ni en los volúmenes que muestra. Las mujeres de la tv tienen todas una belleza parecida, son "la bella" que todos pensamos y entendemos empapados de la visión euro centrista imperante. Una sola belleza, una belleza blanca europea.

Comprobaremos que constituyen un modelo absolutamente hegemónico del que ninguna de las mujeres mediáticas se aparta.

Este capítulo trata sobre la búsqueda de las tensiones que se producen en las mujeres a partir de los parámetros (hacer, pensar, sentir) impuestos por los CF en la tv argentina.

La belleza o mejor dicho la idea de persona bella sería el producto de la media inconsciente, una estadística de la media que todos los individuos de una sociedad tienen de la idea normal de belleza. Es el punto medio entre el gusto individual y lo universal, un acuerdo (Danto, 2005).

La belleza sería la norma que en la imaginación de la sociedad está sobre la belleza humana. Por lo tanto es cambiante de acuerdo a cada grupo humano. En esta investigación se determina cuales son los CF bellos en la tv por la repetición de atributos. Los atributos con mayor frecuencia nos señalan la Moda. Los atributos detectados para definir una idea sobre la belleza femenina que existe en la tv argentina son:

\section{- Europea}

- Blanca

- Joven

- Delgada

- De pechos grandes

- De tono muscular medio o débil

- La cara y los pechos como sus partes más visible. 
- De cabellos lacios, rubios y sueltos

- Con maquillaje pesado

- De hablar poco y en tonos bajos

- Profesionales no universitarias

- Con trabajos rentados

- Que hacen comentarios, cuentan, preguntan, (“chimentan")

- Que tienen roles de sujetos eróticos

Debo señalar primero que si esta "belleza" se convierte en una belleza normativa, esta pretensión de universalidad no va a ver correspondida con la realidad de nuestra población, lo que implica que deberá actuar con muchísima fuerza para normalizar ya que deja excluida a una gran cantidad de mujeres. Y segundo que las categorías que se desprenden de lo que se llamará desde ahora CF televisivo, son:

La forma, la juventud y la seducción, la victimización y la desnudez

\section{Las Formas}

Las formas se corresponden con cuerpos jóvenes, la turgencia y altura de los pechos, los glúteos y etc.

Este valor se entreteje en el concepto de belleza y las mujeres del medio se incluyen utilizando artilugios que van desde el maquillaje, las tinturas, la ropa hasta las rigurosas dietas y cirugías.

Se detectan numerosas intervenciones en los cuerpos, que pueden poner en riesgo la salud de muchas de estas mujeres. En esta re definición de cuerpo la tendencia mayoritaria no es utilizar el deporte y las actividades físicas como medio para lograr el objetivo sino las dietas y los tratamientos llamados de "belleza".

Algunos métodos que utilizan estos tratamientos: 
Una famosa empresa argentina de diagnóstico y tratamiento (Slim) propone para bajar de peso una combinación de nutrición y estética, es simple, entrevistan a la paciente y a través de un diagnóstico, realizan una dieta nutricional y la convocan algunas veces por semana donde le realizan el control de la dieta, masajes y gimnasia; sus productos rezan. "un método de modelación dermotópica local con productos exclusivos en base a principios activos como centella asiática, ginko biloba, que actúan sobre los tejidos mejorando la circulación para que recuperes tu belleza natural."

Otro ejemplo es Dental \& Esthetic Center del Dr Muhlberger Klinik, en la ciudad de Buenos Aires, la cual reza “te ves bien, te sentís bien” ya en el lema la salud queda detrás del aspecto personal y hace responsables de verse bien a cada individuo, si no te ves bien, te sentís mal y es tu culpa. Tomamos uno de sus tratamientos: microlipoescultura no invasiva "Remodela todo tu cuerpo sin cirugías, consiste en la aplicación de productos reductores en las zonas que se desean corregir a través de la técnica de hidrolipoclasia que es una suave mesoterapia más la acción de un equipo de sonido”. La mesoterapia es un tratamiento a base de inyecciones en la dermis de pequeñas cantidades de medicamentos homeopáticos. Cuando se habla de "productos reductores" van desde cremas hasta hormonas generalmente con sus nombres en idioma extranjero al igual que los nombres de los tratamientos lo cual instala desde un comienzo una distancia entre los profesionales y las consumidoras dejando a estas en el lugar de la ignorancia.

Y como "las formas" son formas juveniles otros muchos tratamientos recaen directamente sobre el rostro ya que es la parte mas visible de este CF, por ejemplo: Lifting (con cirugía y sin cirugía), botox, rejuvenecimiento laser, rellenos faciales, peeling, mesoterapia y etc. Todos bajo el objetivo de fortalecer la firmeza de la piel, eliminar arrugas, manchas, secuelas de acné (la mala juventud) y asegurar la piel tersa y luminosa igual a las de los CF televisivos.

“Te ves bién te sentís bien” ¿cuánto tiempo y cuánto cuesta esto?

Lifting: US\$ 2400 /

Cirugía de mamas: US\$ 5000 / 48hs post operatorio y aproximadamente 1 semana para retomar las tareas habituales 
Cirugía de glúteos: US\$ 3000 a 4000 / 48hs post operatorio y aproximadamente 10 días para retomar las tareas habituales

Tratamiento básico para adelgazar Slim:

Radiofrecuencia: entre \$150 y \$200 por sesión, mínimo recomendado 10 sesiones. Sesiones de 1 hora aprox.

Electrodos: \$1500.- ocho sesiones. Sesiones de 1 hora

Peeling: \$350.-

Todos estos tratamientos vienen con la recomendación de asociarlos a otros y hacerlos la mayor cantidad de veces posibles o programar mantenimientos. Si a estos le sumamos las cuestiones estéticas, digamos más comunes para las mujeres argentinas tendríamos:

Peluquería: alrededor \$120.- entre 1 o 4 veces al mes

Manicura (manos y pies): \$80.- una vez por semana

Depilación: \$120.- cada 15 días

Limpieza de cutis: \$100.-

Pilates: \$700.- dos veces por semana

Gimnasio de musculación: \$300 por mes

Por lo tanto viendo los costos y el tiempo que lleva re definir el CF como lo vemos en la tv. notamos que para acercarse a ese $\mathrm{CF}$ los costos monetarios pueden ser muy elevados según el tratamiento pero es imposible no emplear tiempo para realizar estas rutinas. Por lo tanto en el más barato de los barrios o en una lujosa clínica las mujeres emplean tiempo que restarán de su tiempo libre. Creando con todas estas actividades una especie de rutina de embellecimiento que vamos a llamar la $3^{\circ}$ Jornada.

Las mujeres trabajan fuera del hogar $1^{\circ}$ jornada, dentro del hogar en lo que refiere a tareas domesticas, cuidado de niños y familiares $2^{o}$ jornada y esta nueva jornada de embellecimiento crea la $3^{\circ}$ jornada que se suma a un ya agotador día. 
Comúnmente se dice que las mujeres aprovechan su tiempo libre en el shopping, cada una según sus posibilidades ¿pero que hacen las mujeres en el shopping o en los centros comerciales de cualquier barrio? Miran vidrieras, buscan ropa, ven, comparan, aprenden a vestirse o mejor dicho como vestirse según la moda actual. Una moda que acompaña los criterios de belleza, ir de "shopping" es estar otra vez entregada a la $3^{\circ}$ jornada.

Y a diferencia de otras épocas todos los artilugios de belleza, más una dieta disciplinada, hacen posibles definir nuestros cuerpos según nuestros deseos. Más o menos, cada quien dependiendo de sus recursos económicos, su tiempo y su genética obtendrá mayores o menores resultados. Todas las mujeres que se alisan el pelo tienen el pelo lacio. Todas las mujeres que se operan las mamas tienen pechos grandes. Y podría hacer una larga lista comprobando como los adelantos médicos y estéticos llegan al objetivo de modelar el cuerpo. Y siempre habrá una droga que acelere esos resultados. Asistimos a la era donde los artilugios se hacen realidad y esto ha provocado una corrida hacia ellos. Hoy es posible manipular nuestro cuerpo y modelarlo y en esta obsesión por las formas el cuerpo se ha vuelto un objeto de mercado.

Para las mujeres que trabajan en los medios televisivos esta $3^{\circ}$ jornada se vuelve, por lo que la investigación demuestra, una obligación cuyo punto álgido es el dinero que deben emplear en ella, dinero que deben invertir en su cuerpo para poder conseguir el trabajo mediático y para mantenerse en el. Las formas del cuerpo vienen entonces expresar el ingreso a la hegemonía como a un médico se lo define por sus capacidades a las mujeres en la televisión se las define por sus formas. Como las estudiantes de medicinas estudian para definirse como médicas, las mujeres mediáticas tallan sus formas para ingresar en el medio. Rehacer o resaltar partes de su cuerpo es una obligación aceptada llamada por las producciones televisivas "criterios artísticos". Y este hecho implica una cierta cantidad de dinero. Las jóvenes que sueñan con el ingreso a este medio llegan de todo el país a la capital y son de todas las clases sociales, por lo tanto el acceso a las primeras cirugías es difícil. Esta cuestión, que no escandaliza a nadie en el medio, es aceptada por las mujeres como un requisito más. Antes para estar en las pantallas había que ser bella y tener algún talento, ahora hay que tener grandes lolas, unos buenos glúteos y estar dispuesta a mostrarlos cuando así lo requieran. 


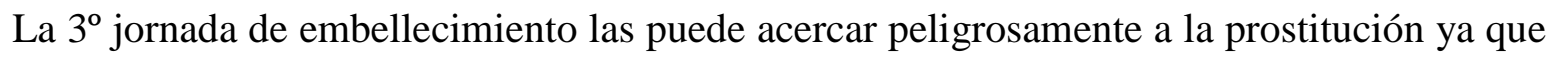
deben invertir mucho más dinero que sus pares hombres para conservar el trabajo, con lo cual a igual salario ellas ganan menos. Y se afirman en la desigualdad del modelo hegemónico donde el CF permanece en una circulación mercantil.

Dice Pierre Bourdieu:

"el cuerpo se convierte en el campo de batalla de una lucha cuya finalidad es la aceptación de la condición de dominado (quien somete su cuerpo a la mirada del otro) y la percepción del grupo dominante se identifica con la lucha de clases en la medida en que se trata de imponer las características de un grupo después de haberlas legitimado y hecho reconocer como ejemplares

Vemos los CF televisivos aceptando pasivamente las obligaciones impuestas y la imposición de una clase dominante (el estereotipo de mujer blanca europea) en su imagen reproducida cientos de veces en las pantallas de tv hasta volverla un ejemplo legitimo.

\section{La Juventud y la Seducción}

Las grandes casas de cosméticos dicen: "la juventud está en tus genes” (Lancôme), “el gen de la juventud existe" (Avon). Esta juventud está directamente relacionada con la vitalidad y con la sensualidad femenina ¿Qué es lo realmente diferente en una mujer según sus años? ¿Qué puede ser definitorio entre una y otra? La posibilidad de ser madre esa una de esas diferencias, desde hace mileños resultan más atractivas las mujeres fértiles que las infértiles por una cuestión de sobrevivencia pero en la actualidad parece haber nuevos parámetros.

El concepto de tiempo ${ }^{17}$ en nuestra época puede dar datos sobre esta codiciada juventud de los CF televisivos. Es evidente el deseo de no envejecer de la mayoría de las personas que transitan la TV, la vejez es la última parte de la vida y la más cercana a la muerte. Deberíamos envejecer felices de tener la posibilidad de la vida sin embargo la angustia de

\footnotetext{
${ }^{16}$ Bourdieu, Pierre. La dominación masculina. Barcelona. Anagrama Colección Argumentos. 2000

17 Tomado de Ariès, Philippe. El hombre ante la muerte. Buenos Aires. Aguilar, Altea, Taurus, Alfaguara. 2011
} 
morir no nos da tregua. Desde el siglo XX con el triunfo de las técnicas de la industria, de la agricultura, del pensamiento científico, los avances tecnológicos y científicos cubren a occidente e impulsan un cambio en las políticas, en la demografía, en la economía y en la sensibilidad de las sociedades actuales. En nuestra sociedad el concepto de tiempo se ha vuelto tiempo presente desplazando al pasado e incluso al futuro. El pasado ya no es útil para comprender el presente y el futuro no nos compromete, es en el presente que debemos ser felices, que debemos estar vivos. Es en un presente hipertrofiado donde nuestra sociedad se mueve vertiginosamente dejando atrás a hombres, mujeres y objetos. El consumo de bienes es veloz, los beneficios deben ser inmediatos, es primordial estar actualizado porque todo puede pasar a ser obsoletos en cualquier momento y deberá reemplazarse; ya nada se arregla: ropa, televisores, computadoras, teléfonos, etc todo es efímero.

Los medios de comunicación comprimen el tiempo "la noticia al instante", reciclan y producen los sucesos inmediatamente a veces sin tiempo de compaginar las imágenes transmiten en crudo para tener la primicia, lo llaman "tiempo real". Las innovaciones tecnológicas, los aviones, todo va comprimiendo y suprimiendo el tiempo "cene en Buenos Aires y desayune en Nueva York" anuncia una publicidad.

Y para este presente la edad es un recordatorio del paso del tiempo y de la cercanía de la muerte. La vejez no es más el lugar del reconocimiento sino mas bien el lugar de la precariedad y la fragilidad humana. Se teme envejecer por miedo a perder el trabajo, los afectos, a la soledad, a no ser valorados. Se teme envejecer porque nos recuerda que vamos a morir. Y la muerte es en la actualidad ocultada, no hay duelos salvo para los hombres de Estado, el cuerpo enfermo doliente, sin vida ha quedado recluido en la disciplina y el secreto de los hospitales. Sucia y fea la muerte ha sido ocultada de nuestra vista. "La muerte ha dejado de ser admitida como un fenómeno natural, necesario. Es un fracaso, un business lost" (R.S Morrison). Y en el cuerpo se concreta esa separación entre la vida y la muerte. El envejecimiento pone en la piel el signo del cambio, las arrugas, los movimientos más lentos, el color del cabello, la mirada, la blandura de los músculos. Este nuevo cuerpo interrumpe en nuestra sociedad veloz y extrovertida. Y es rechazado. 
Tan rechazado es un cuerpo anciano que se busca, al menos, retardarlo. A fuerza de métodos invasivos o no pero con mucha disciplina los años 2000 dan cuenta de los nuevos “40" o los nuevos "50" donde las personas de esas edades parecen mucho más jóvenes de lo que el imaginario colectivo cree. Se corrió a la vejez más adelante y hemos sido las mujeres quienes empujamos con más fuerza esa frontera. Sin embargo, parodiando el reclamo de la primera ola del feminismo "igualdad con los hombres", hoy parecen gritar “igualdad con las jóvenes” con las jóvenes de verdaderos 20 años. Usan la misma ropa, posan de igual manera y buscan parejas más jóvenes que ellas. Parecen pedir igualdad de trato que las jóvenes aunque simplemente quieran permanecer incluidas un rato más en la televisión.

Sin embargo las diferencias que el paso de los años deja en cada cuerpo podría ser apreciado, podría ser bello. Lo que un cuerpo después de haber vivido 50 años puede expresar es interesante. La mirada, el cambio de color en los cabellos, los movimientos, las arrugas en el rostro, la performance sexual, todo en estos cuerpos nos habla de un relato que la televisión no está dispuesta a escuchar ¿el resto de la sociedad si?

Hay diferencias entre el envejecimiento de los hombres y las mujeres, todos hemos escuchado la frase "es un galán maduro" "que bien le sientan los años" al parecer en el juicio social los varones pueden, tienen la posibilidad, de que los años les den una seducción especial. Una posición económica sólida y su experiencia pueden volverlo un seductor, "un galán que peina canas". Y no solo eso, la frase "el hombre tiene la edad de la mujer que lo acompaña" responsabiliza a las mujeres del envejecimiento de ellos o de su prolongada juventud.

En cambio las mujeres entradas en años no reciben esos adjetivos sino otros siempre negativos: "es una vieja loca", "veterana", "la millonaria” y en el supuesto que una mujer madura intente seducir a un joven atraería sobre sí un juicio social para nada complaciente y en el caso de considerar esto de manera positiva el juicio de valor caerá sobre el joven varón que disfruta del dinero de la "veterana". En el imaginario social a la mujer los años le quitan vitalidad y seducción. Esto impone una condena que vuelve invisibles a las mujeres maduras y se transluce con esos adjetivos negativos. Ese ser invisible es sentir que la mirada de los otros deja de fijarse en una, es cuando el juego del deseo nos deja de lado 
entonces comenzamos a creer que envejecemos, que quedamos fuera, un juego entre lo que sentimos y lo que los demás nos dicen que ven en nosotros. Y esto en las mujeres parece darse con anterioridad a los hombres.

\section{La Victimización}

Otra categoría de los CF televisivos es la Victimización femenina, se analizará este concepto con el soporte de Élisabeth Badinter ${ }^{18}$.

Badinter habla de la existencia de una perspectiva victimista que instala que natural o cultural la supremacía masculina es universal y la posición de las mujeres en cualquier lugar o tiempo es de inferioridad con lo cual son víctimas reales o potenciales "Por ende, la victimización del género femenino permite unificar la condición de las mujeres con el discurso feminista bajo una bandera común. Así, el rompecabezas de las diferencias culturales, sociales o económicas se desvanece con un toque de varita mágica. Incluso se puede comparar, sin sentir pudor, la condición de las europeas con la de las orientales y afirmar que en todas partes las mujeres, por ser mujeres, son víctimas del odio y la violencia" $" 19$

En la actualidad las mujeres argentinas hacen visibles sus cuerpos en la tv pública. Desde la publicidad de jabón Cardum donde Susana Gimenez mostraba los hombros y su rostro sugestivo hasta las vedettes de hoy hay largo camino recorrido pero pocos cambios.

Pocos cambios.

La publicidad de Cardum sale al aire en 1969, en ese entonces Susana Giménez era una modelo poco conocida que bailaba en los boliches de moda. La publicidad une a la empresa de jabones con una joven que muestra una sexualidad desinhibida, para la cual bañarse es un placer. El placer se muestra en su rostro de ojos sugestivos y boca entreabierta, sus hombros inclinados y un segundo de espalda que parece esconder algo maravilloso. Toda

\footnotetext{
${ }^{18}$ Badinter, Élisabeth. Hombres Mujeres Como salir del camino equivocado. Buenos Aires. Fondo de cultura económico. 2003

19 Ibidum.
} 
sensualidad o solo sensualidad vuelven a esta mujer un icono en la tv argentina, icono que resume los pocos cambios que desde hace 43 años tienen los CF mediáticos. Ella representa el éxito profesional y económico, la popularidad, la libertad sexual, la belleza y al mismo tiempo y sobretodo detrás de todo esto es la mujer que no logra una pareja estable, a quien los hombres la roban, la engañan y le pegan ${ }^{20}$. Susana Giménez es un icono que muestra la libertad sexual femenina pero con algunas condiciones morales muy predominantes: muchos compañeros sexuales y una renuncia a la vida familiar con una maternidad que no se expone. Una maternidad oculta y una sensualidad expuesta. Con respecto al dinero aunque gana millones varias veces es "engañada" con lo cual su manejo del mismo parece ser malo. Se hace famosa por mostrarse como sujeto erótico. No muestra sus capacidades intelectuales ni su educación. Cuando forma pareja es sometida físicamente o la roban. Ella es una mujer empresaria y libre pero no se muestra así, no hace visibles sus avances como sujeto, su maternidad, ni sus pensamientos, muestra sus debilidades y nos deja quedarnos con sus tonterías.

Si pensamos en el icono masculino de la tv actual pensamos en Marcelo Tinelli que con iguales éxitos económicos y empresariales, no muestra ninguna debilidad. Es el jefe absoluto en su empresa. Dos matrimonios, cuatro hijos de madres distintas, con los cuales el pasea y se muestra como una familia feliz (con una madre o con la otra o con ninguna) ${ }^{21}$. Sus parejas no lo roban, ni le pegan, ni lo dejan, él se divorcia de común acuerdo. Sorprendentemente Susana Giménez que ha hecho de su imagen un imperio no se corre del lugar de víctima. Mientras su par masculino ostenta el poder de sus logros ella es la tonta millonaria.

Susana colocada en el lugar de la victima puede igualarse o solidarizarse con el colectivo de mujeres cruzadas por la pobreza, la falta de educación y la dominación masculina

\footnotetext{
${ }^{20}$ Véase sobre Susana Gimenez http://edant.clarin.com/diario/1998/02/13/e-03101d.htm http://www.lanacion.com.ar/1325974-susana-gimenez-hace-20-anos-que-los-hombres-me-sacan-plata http://www.hola.com.ar/1428175-susana-gimenez-y-su-hija-se-fotografiaron-juntas-por-primera-vez ${ }^{21}$ Véase sobre Marcelo Tinelli http://www.ratingcero.com/notas/79578-marcelo-tinelli-le-festejo-elcumpleanos-su-hija-juanita http://exitoina.com/2011-10-06-75282-la-familia-unida-marcelo-tinelli-con-sus-hijas-y-soledad-aquino/ http://www.hola.com.ar/1527443-tras-separarse-marcelo-tinelli-se-refugio-en-su-familia http://www.diariopopular.com.ar/notas/107085-tinelli-y-paula-robles-undivorcio-buenos-terminos
} 
cuando en realidad tiene mucha más cercanía con su par masculino que con cualquier mujer de clase media o baja.

La narrativa de la victimización hace que las mujeres no luchen por sus derechos, no las lleva a rebelarse sino que parece completar el sometimiento. Esta confusión de victimas no hace otra cosa que fijar a todas las mujeres en un rol de dominadas. Y quienes podrían representar la libertad económica, sexual y la diferencia en la maternidad terminan siendo los símbolos de un modelo antiguo que no solo se niega a caer sino que se fortalece con la bella estúpida. Y esa misma confusión hace olvidar a las verdaderas víctimas que no son la mayoría de las mujeres y que podrían y deberían ser auxiliadas eficazmente.

\section{La Desnudez}

Es cierto que en este largo camino desde aquella propaganda de Cardum el CF se ha hecho mucho más visible. Mostrar la piel del cuerpo en tv es usual y los semi desnudos se han vuelto naturales. Lo importante es saber si esta desnudez es sinónimo de libertad o no.

En una primera observación es notoria la diferencia en los programas nocturnos cuando se observa a las mujeres bailar con diminutas bombachas y pezoneras mientras sus compañeros varones están con las piernas y el torso tapado. Entonces no es igual la visibilidad del cuerpo masculino que del femenino.

Históricamente el CF viene sacándose la ropa, liberándose de ataduras desde finales del siglo XIX cuando comienza a caer en desuso el corset y las piernas regresan a las playas de Francia. Según Vigarello (2005) la tragedia es que viene acompaña del ingreso del espejo en las puertas de los roperos de las habitaciones, el discurso del régimen para adelgazar ciertas partes del cuerpo y la nueva práctica de un culto a la belleza que requiere un tiempo privado para entregarse a maquillaje, a bañarse y a vigilar y verificar los contornos del propio cuerpo. Y la industria de belleza comienza un vigoroso crecimiento que continua hasta nuestros días. Perfumes, peinados, ropa, cremas, adornos, regímenes, tratamientos, cosméticos. Una industria que crece, que promueve, que impone pero que también acompaña el devenir social con respecto a la belleza femenina. 
Se buscan las consideraciones políticas de esta cuestión: "estas consideraciones surgen cuando los miembros de un grupo comienzan a pensar que han estado tratando de adaptarse a una norma de belleza que en realidad les vino impuesta por una clase política dominante, por los hombres en el caso de las mujeres, o por los blancos en el caso de los negros o por los gentiles en el caso de los judíos. Cuando la posibilidad de la imposición paso a un plano de toma de conciencia, las practicas embellecedoras cambiaron de repente"22

Por ejemplo el cabello rizado, un componente casi vital diríamos de la población negra, fue alisado durante años hasta por el propio Malcon $\mathrm{X}$ quien sería más tarde uno de los representantes en la lucha por los derechos civiles de los afroamericanos en EEUU. La cultura negra cambio también a partir de cambios cosméticos como el cabello, la elección de nombres africanos para los niños, el cambios de religión y el uso de vestimenta africana.

Cuando comienza el primer movimiento feminista en los años veinte donde las mujeres buscan la igualdad de derechos, el CF se rediseño para que nada en su figura se diferencie sustancialmente de sus compañeros varones, los atributos esencialmente femeninos se ocultaban o mejor dicho no se destacaban. La moda impuso una invisibilidad de los pechos, el corte de los cabellos y los talles alargados.

Para la década del $60^{\prime}$ y contemporáneo al movimiento afro, las mujeres se liberaron de los corpiños dejando en libertad los pechos que mostraban los pezones a través de remeras y blusas, era la liberación sexual, las pastillas anticonceptivas dieron a estas mujeres el poder de planificar su maternidad y con ello un cambio en la sexualidad femenina que lentamente fue parte de todas las mujeres occidentales.

¿Qué paso desde entonces con estos pechos liberados en nuestro país, en la televisión? En 50 días de observación no vimos ningún pezón que se dibuje o se esboce debajo de la ropa. Comparemos dos fotografías de dos mujeres argentinas vedettes mediáticas de diferentes años:

${ }^{22}$ Danto, Arthur C. El abuso de la belleza, la estética y el concepto de arte. Buenos Aires. Paidós 2005 


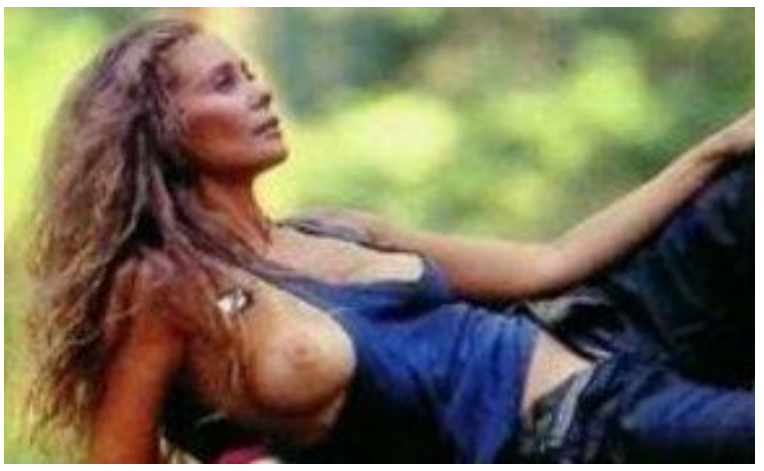

Camila Perisse icono sexual de la década de los 80.

Obsérvese sus pechos caídos naturalmente, el cabello despeinado, su mirada de éxtasis, el jean abierto, la remera caída. Un make up leve sobre las mejillas. La pose relajada como si el cuerpo viniera de alguna acción intensa. El fondo de naturaleza.

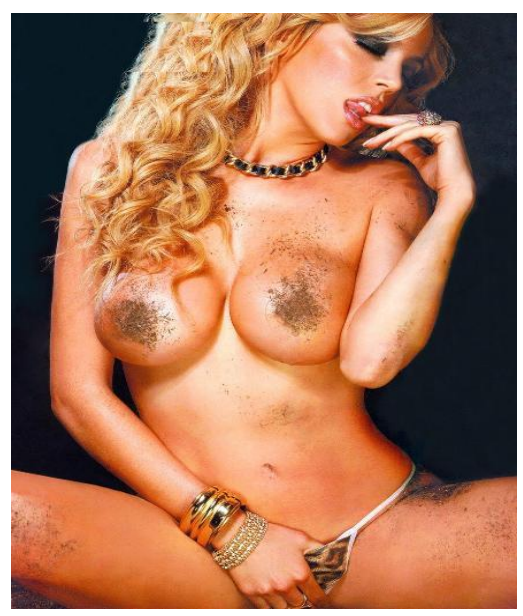

Virginia Gallardo vedette actual.

Obsérvese la pose rígida, los pezones tapados, la bombacha y la mano delante del pubis como una insinuación de auto goce. El cabello platinado, la boca entreabierta, las piernas separadas en tal vez su extensión máxima. Solo vestida con una tanga y bijouterie. Su piel da sensación de luminosidad, de brillo, un make up pesado sobre los parpados especialmente y los labios dan privilegio a los blancos dientes. Un fondo negro que marca aun más sus cabellos rubios y su piel blanca. 
Son pocas las partes del cuerpo tan sensibles como los pezones, zona erógena que estimulada simboliza la receptividad a tener relaciones sexuales y más aun, según una nota del diario Perfil ${ }^{23}$, -según un mapa cerebral del placer femenino,- que confirma a los pezones como zona erógena y a las mujeres como capaces de llegar al orgasmo solo con la estimulación de los mismos: "Lo inesperado fue, además, que la auto estimulación del pezón activa las mismas aéreas cerebrales que la región genital, lo que explicaría por que es una zona erógena en la mujer” señalo Barry Komisaruk.

En los 90' se crean los corpiños con aro, una fina varilla de metal se incorpora a la parte inferior de la taza del corpiño y con esto se logra un efecto de elevación en los senos, los pezones desaparecen de escena y entonces de la natural de caída pasamos al ascenso casi adolescente de los pechos, de la flexibilidad del musculo a la turgencia y de la visibilidad de los pezones al ocultamiento.

Se intuye que las partes del cuerpo que se ocultan son las zonas erógenas capaces de alcanzar el orgasmo femenino. En cambio las zonas que quedan al descubierto son aquellas que sirven de estimulación visual a los demás como la parte superior de los senos (para lo cual es necesario un corpiño especial). No parece inocente el punto de ocultar lo que sería el gozo femenino y dejar al descubierto el gozo ajeno. Cuando al principio de esta tesis se comentan las experiencias de Virginia Woolf ${ }^{24}$ una de ellas es la roca donde choca cuando piensa en decir la verdad acerca de sus experiencias en tanto cuerpo, cuerpo femenino. Y si se traza una línea de unión aquella roca es ahora este ocultamiento, esta invisibilidad del goce femenino.

La liberación sesentista de los pechos ha sido aplacada y en su lugar han sido colocados estos nuevos pechos, normalizados en sus contornos y al servicio del goce "de otros".

Aquel discurso que hablo de la liberación sexual fue derrotado por este otro discurso que sujeta a las mujeres como objeto de deseo masculino. Las imposiciones sobre la belleza sean puesto rígidas y es difícil encontrar puntos de quiebre. Las mujeres se incluyen en el modelo estético televisivo provocando la mirada de los demás mientras ellas protagonizan

\footnotetext{
${ }^{23}$ (Ballarino, 2011) según una investigación de la Universidad de Rutgers en EEUU a cargo del biólogo Komisaruk y publicada en el Journal of Sexual Medicine.

${ }^{24}$ Pagina 6
} 
en su propia piel la larga lista de imposiciones de un modelo de belleza que les es ajeno. Un modelo que se reproduce minuto a minuto en las pantallas de tv. Pantallas que, como los espejos de los viejos roperos de final del siglo XIX, invaden las habitaciones modernas vigilando y verificando como es nuestro CF. Mostrándonos como debemos ser para transitar el camino hacia la hegemonía. La desnudez ha traído disciplina.

\section{Las Pasiones}

Para finalizar este capítulo ¿que moral sexual dicen tener o parecen tener esas bellas, jóvenes y seductoras mujeres mediáticas? Se retoma el item de las mujeres como objeto de deseo masculino representadas en aquellas que aparecen como sujetos eróticos. Mujeres que venden el poder de satisfacer el deseo sexual masculino, se observaron y analizaron en la grilla del capitulo precedente, en este punto se señalan algunas frases escuchadas en los programas:

- “me pagan para decir que me acosté con él”.

- "van en bolas y excitan a los hombres"

- "para entrar a trabajar hay casting sabana"

- "tenía un volteadero el productor"

- "viene con minifalda que provoca"

- "se acuesta con medio país por eso es famosa"

- "no calentas"

- "no creo en tu espiritualidad porque tenés siliconas"

- "sos una mujer muy sexy, das mosquita muerta"

- “ellas quieren que las llamen al $4^{\circ}$ piso" (donde trabaja el jefe)

- “¿vendes tus favores sexuales?”

- "una mujer joven y bella que merece lucir todos sus encantos"

- "me hice la cola, las tetas, los dientes, lo hice porque quise"

- "hay casting sabana y mujeres trepadoras"

- "hay chicas que tienen relaciones con él para trabajar" 
- "la Pradon lo dice"

- "si esas piernas hablaran"

- "facturan con la cola y con las lolas"

- "si me la hubieran pedido se la hubiera entregado" ( por una chica joven)

- "si saliera con Marcelo estaría este año en el Bailando"

- "a él le gustan las fiesteras"

- "se hacen las santurronas pero yo no"

Estos dichos hablan claramente sobre situaciones de acoso sexual, delatan un intercambio de dinero o puestos de trabajo por alguna modificación corporal o favor sexual.

Y a la vez acusan a las propias mujeres de aceptarlo sin comprender que ellas son las verdaderas víctimas. El acoso sexual es producto de una posición desigual entre las personas de un mismo ámbito laboral. Insinuaciones sexuales, solicitudes de favores sexuales o conductas físicas o verbales de naturaleza sexual cuya aceptación o no, por parte de la mujer, pone en riesgo la obtención del empleo, o lo afectan o interfieren en la eficiencia del trabajo. Todos los trabajadores de la tv parecen conocer estos "sobornos sexuales" o "promesas de beneficios" o simple coerción sexual. Sin embargo no encontramos denuncias judiciales acerca de este tema.

No obstante, lo que demuestra que esto sucede, es que en la administración pública nacional se ha legislado al respecto "...el acoso sexual, entendiéndose por tal el accionar del funcionario que con motivo o en ejercicio de sus funciones se aprovechare de una relación jerárquica induciendo a otro a acceder a sus requerimientos sexuales, haya o no acceso carnal” ${ }^{125}$ pero en los medios de comunicación masiva parece aceptarse mansamente que esto suceda con algunas o todas las mujeres del medio. Callan las mujeres, callan los hombres.

El discurso televisivo está manchado de desigualdad, mientras parece haber gran libertad sexual en las mujeres y roles compartidos el discurso nos habla de prostitución, de acoso sexual, de roles dominantes masculinos, de cuerpos vistos como objetos. La desnudez femenina en las pantallas de TV ha traído disciplina y mercantilización.

${ }^{25}$ Decreto 2.385/93 sobre Acoso Sexual en la Administración Pública Nacional. 
Es una televisión abiertamente heterosexual y el deseo es solo masculino. La verdad sobre las pasiones femeninas no es dicha públicamente, ni aceptada ni rechazada es ocultada, como se ocultaron los pezones. El deseo sexual femenino es difícil de encontrar en la televisión. Y esto termina de definir los CF mediáticos.

¿Qué pasa con el deseo sexual femenino fuera de las pantallas? El placer femenino es poco investigado por la comunidad científica. En septiembre del 2011 se publica en Revista Cubana de Investigaciones Biomédicas un trabajo "Anorgasmia femenina como problema de salud" que intenta demostrar que la falta de orgasmos en las mujeres es un problema de salud.

En el 2008 se publica en Malaga, España un trabajo "Evaluación y tratamiento de la anorgasmia femenina" donde concluyen que a pesar de la alta incidencia que tiene la anorgasmia femenina "en definitiva, no se dispone de ningún fármaco que haya demostrado ser eficaz, como ocurre en la disfunción eréctil del varón, por lo que la estrategia terapéutica mas efectiva en la actualidad sigue siendo la terapia sexual." 26

Pero la más relevante de las investigaciones para nosotros es la de dos médicos argentinos: Leo Roberto Gindin, medico sexólogo del CETIS (Centro de Sexología. Buenos Aires) y Diana Resnicoff (psicóloga y sexóloga clínica) "Nuevos y viejos medicamentos en sexualidad femenina" ${ }^{27}$ donde se hace una revisión del uso de distintos medicamentos que tienen potencial para aumentar la calidad de la respuesta sexual en las mujeres. Según este trabajo los trastornos sexuales afectan aproximadamente a la mitad de la población y están asociadas a sufrimiento personal. El tratamiento de las disfunciones sexuales femeninas siempre estuvo ligado a la psicoterapia y solo recientemente se considero el uso de medicamentos para estos trastornos. Sin embargo las instituciones que proveen fondos dudan en apoyar la investigación en disfunciones sexuales dado el carácter controversial y político de la historia de la investigación sexual. En nuestro país la medicina prepaga y las obras sociales tratan de excluir la sexualidad de entre sus prestaciones y de hecho, un

\footnotetext{
${ }^{26} \mathrm{http://www.elsevier.es/sites/default/files/elsevier/pdf/262/262v6n2a13129600pdf001.pdf} \mathrm{"Evolución} y$ tratamiento de la anorgasmia femenina" Francisco Cabello Santamaria. Instituto Andaluza de Sexologia y Psicologia. Malaga. España.

${ }^{27}$ http://www.aap.org.ar/publicaciones/forense/forense-12/tema-7.htm "Nuevos y viejos medicamentos en sexualidad femenina" Leon R.Gindin, Diana Resnicoff
} 
excelente medicamento como el citrato de sildenafil, no tiene cobertura médica. Tampoco existen menciones de problemas sexuales en los nomencladores médicos. Resumidamente las conclusiones de este trabajo dicen. “...muchos medicamentos son reforzadores del funcionamiento sexual en mujeres. Ninguno de ellos ha sido estudiado sistemáticamente en poblaciones clínicas femeninas. Pareciera existir resistencia a dirigir una investigación sobre la sexualidad de las mujeres, particularmente con respecto a substancias que pueden mejorar el deseo y el funcionamiento sexual. Dada la falta de conocimiento sobre la sexualidad femenina y la dificultad para obtener financiamiento en esta área polémica, los investigadores son renuentes a realizar estudios de este tipo.

Con el tiempo se ha reconocido la posibilidad de mejorar la calidad de vida de las mujeres a través del tratamiento farmacológico de los trastornos sexuales femeninos. Los clínicos están empezando a usar algunas de estas medicaciones, solas y combinadas en los problemas sexuales refractarios. Sin embargo, se aconseja cautela porque estas medicaciones no están aprobadas por la F.D.A.

...la escasez de la investigación científica y clínica en el campo de la sexualidad femenina nace más de factores sociológicos que la necesidad médica. Los obstáculos al intento de realizar este tipo de investigación están bañados en prejuicios y miedos sobre la sexualidad, particularmente la sexualidad femenina, que están en nuestra cultura. Aunque estas influencias negativas son tan vigentes como antiguas, este tema y la investigación en el mismo, apunta a avanzar un paso más al frente en este área tan crucial para el bienestar mental completo de todos (hombres y mujeres por igual)."

El CF queda dividido ¿Qué clase de pasiones sexuales se pueden experimentar si el goce es solo de los otros? ¿Qué pasión sexual podemos sentir solo a cambio de fama y dinero? ¿Entonces el erotismo femenino queda recluido al intercambio de dinero? ¿Mi cuerpo es solo en función de los otros? ¿Y en qué lugar está el amor? ¿En qué lugar están las parejas como iguales, como duplas, como semejantes? ¿A dónde se ha escondido la pasión por la pasión, por el gusto, por el placer, por la simple sensación tocar y que me toquen?

De la moral cristiana que mantuvo a las mujeres castas y puras para conservarlas dentro del matrimonio, nos encontramos hoy frente a un CF que se envuelve en deseos ajenos. Un 
cuerpo libidinoso, dispuesto a entregarse a los placeres sexuales sin conflictos religiosos ni morales. Un cuerpo exhibicionista, capaz de modificarse, de múltiples parejas pero con contradicciones según las siguientes frases televisivas:

- "el que se quiere casar no quiere un tentempié"

- "en casa la saco seguido" ( refiriéndose a que podía ser una mujer muy sexy)

- "las mujeres son divinas pero las hormonas se le cruzan"

- "la madre que abandona a su hijo es mala"

- "mis hijos me quieren ver bailar pero como les explico ..." (algunas posturas en el show de baile nocturnos)"

- "se trata de perreo y ella se hacia la lánguida"

- "tiene dos hijos, recién fue mama, el marido tiene plata ¿necesita trabajar tanto?"

- "no la conozco tanto para saber si tiene corazón o alma"

- "no sabe hacer nada" (referido a las tareas hogareñas)"

- "dejo su carrera para estar con él"

- "muy pocas mujeres han podido transcender lo físico" (físico por cuerpo)"

- "se hacen las santurronas pero yo no"

- "hace 6 meses que no hago nada" ( que no tiene relaciones sexuales)"

- "fue cuando no era madre, era joven"

- "no pareces bióloga jestas perfecta!" (perfecta por su cuerpo)

- "era capaz de hacer sus propios chistes"

- Pregunta si es hombre: "como cocinas las mollejas?"

Si es mujer: "como cocinas milanesas?"

- "estudie de mañana para no molestar a mi marido"

En estas frases (no se transcriben las de la novela mexicana por ser extranjera) se detectan competencias. Se hacen referencias muy marcadas hacia la maternidad tradicional hasta en la edad que se debe ser madre, o sea, hay una edad establecida para ello. Hay estereotipos marcados como: madre/joven, ciencia/fealdad, mujer/ama de casa, mujer/ no creativa por lo tanto hombre/creativo, ama de casa/ trabajo dentro del hogar por lo tanto hombre/ trabajo fuera del hogar, mujer/destino biológico, erotismo/ pecado, castidad/hijos/matrimonio. 
Hay referencias muy profundas del sistema patriarcal en imágenes que son contradictorias como una mujer semidesnuda frente a una cámara de televisión que diga que hace 6 meses que no tiene relaciones sexuales ¿Qué está diciendo en realidad?

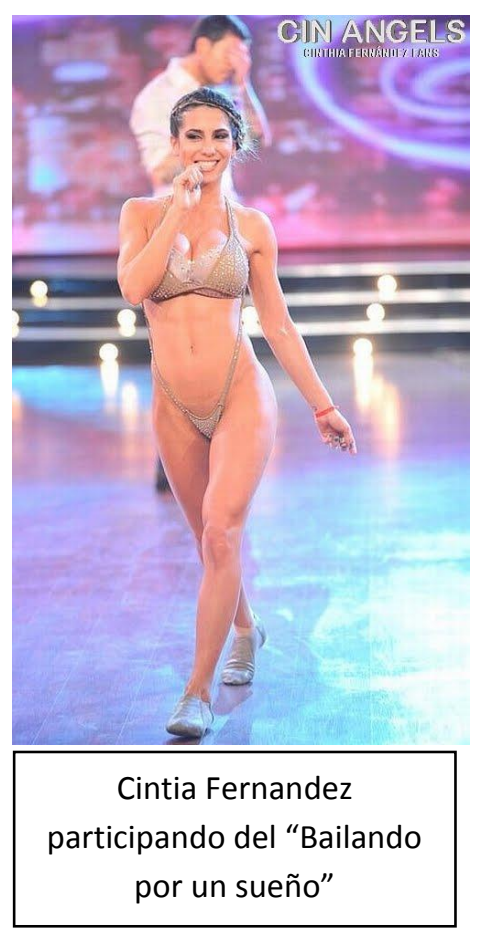

Tal vez no haya contradicción en un mundo heterosexual con matriz patriarcal ella simplemente dice "heme aquí, tómame" o ¿Cuánto estas dispuesto a pagar por mi?

Las pasiones femeninas todavía permanecen en el interior de las habitaciones, la ciencia no está aun dispuesta a investigarlos pero la tv está decidida a guiarlos. 
Por un lado la tv puede ser tomada como el lugar donde algunos géneros culturales ponen en escena, de manera fiel o lo más cercano a eso, la realidad. Desde el arte, la política, el periodismo y la ciencia, la tv puede ser el instrumento que comunique, informe, enseñe a los televidentes sobre diversos temas. Forme, marque pautas. Una televisión que le hable a ciudadanos. Que sea un medio de comunicación para todos hecho por unos pocos.

Por otro lado puede ser otro lugar parecido también a la realidad pero esta vez a una realidad diferente, más banal, más vulgar. Un lugar de entretenimiento, de emociones descontroladas, de noticias sin verificaciones. Un lugar de espectáculos, de magias convertidas en realidad. Donde alguien feo puede volverse bello, donde los pobres se vuelven ricos, donde los invisibles se hacen visibles. De bajo contenido intelectual esta tv no se centra en un discurso narrativo sino en lo visual. Es una tv que se mira a si misma, que marca tendencias. Que le habla a un público. Un medio de comunicación con la participación de muchos para todos.

En el horario de 14 a 16 hs, en el cual realizamos nuestra investigación, todos los programas emitidos en los canales de aire se inscriben en este último lugar que podemos llamar de la tv espectáculo.

La primera gran crítica que tuvo la televisión vino de parte del cientista político Giovanni Sartori en su libro Homo Videns publicado en 1997 con tanto éxito que tuvo dos nuevas ediciones en 1998 y 1999. En el Sartori enuncia su tesis: el aparato cognitivo del homo sapiens estas siendo modificado por la televisión y el video, a tal punto que llega a anular su pensamiento y lo hace incapaz de articular ideas. La cultura audiovisual es inculta piensa Sartori por lo que del homo sapiens, producto de la cultura escrita, se ha pasado al homo videns, producto de la imagen.

"la televisión -como su propio nombre indica- es ver de lejos (tele), es decir, llevar ante los ojos de un público de espectadores cosas que puedan ver en cualquier sitio, desde cualquier lugar y distancia. Y en la televisión el hecho de ver prevalece sobre el hecho de hablar, en el sentido de que la voz del medio, o de un hablante, es secundaria, está en 
función de la imagen, comenta la imagen. Y, como consecuencia, el telespectador es más un animal vidente que un animal simbólico. Para él las cosas representadas en imágenes cuentan y pesan más que las cosas dichas con palabras. Y esto es un cambio radical de dirección, porque mientras que la capacidad simbólica distancia al homo sapiens del animal, el hecho de ver lo acercan a sus capacidades ancestrales, al género al que pertenece la especie homo sapiens." 28

Hay varias cuestiones interesantes en este párrafo: primero el poder ver cosas que suceden en cualquier parte del mundo. Esto globaliza, une a todos los televidentes en un mismo grupo de observadores, en una masa que puede tener un efecto negativo ya que vuelve importante lo que sucede lejos y minimiza lo cercano. Se puede ver desde Buenos Aires como los niños mueren de hambre en Tucumán mientras se olvida al niño que limpia vidrios en la esquina.

Segundo, se manifiesta la supremacía de las imágenes sobre las palabras e imposible no coincidir en que la televisión es imagen. Pero no se trata de una imagen que produce conceptos sino una imagen cruda, concreta. Como bien lo ejemplifica Sartori "La imagen de un hombre sin trabajo no nos lleva a comprender en modo alguno la causa del desempleo y cómo resolverlo." (Sartori, 2011) no lleva a la abstracción de un mundo político y económico sino a un mundo sensible, la situación angustia o enoja de hecho. La tv impulsa a los sentimientos y a las emociones y de esa manera impacta en la vida real.

Entre la televisión lúdica de espectáculos de entretenimientos y juegos y la tv que informa no hay tiempo para reflexionar, no hay lugar para detenerse y profundizar un tema. No hay especialistas, ni ciencia de ningún tipo. La televisión entabla un vinculo negativo entre la urgencia del tiempo y el pensamiento, es difícil pensar en un corto tiempo. Bourdieu profundiza esta cuestión: "Y uno de los mayores problemas que plantea la televisión es el de las relaciones entre el pensamiento y la velocidad. ¿Se puede pensar atenazado por la velocidad? ¿Acaso la televisión, al conceder la palabra a pensadores supuestamente capaces

\footnotetext{
${ }^{28}$ http://es.scrihttp://www.scribd.com/doc/13042160/Giovanni-Sartori-HomoVidensbd.com/doc/13042160/Giovanni-Sartori-Homo-Videns
} 
de pensar a toda velocidad, no se está condenando a no contar más que con fast thinkers, con pensadores que piensan más rápido que su sombra...?

Hay que preguntarse, en efecto, como son capaces de responder a estas condiciones absolutamente particulares, como consiguen pensar en unas condiciones en las que nadie es capaz de hacerlo. La respuesta, me parece, es que piensan mediante «ideas preconcebidas», es decir, mediante «tópicos». Las «ideas preconcebidas» de que habla Flaubert son ideas que todo el mundo ha recibido, porque flotan en el ambiente, banales, convencionales, corrientes; por eso, el problema de la recepción no se plantea: no pueden recibirse porque ya han sido recibidas. Ahora bien, trátese de un discurso, de un libro o de un mensaje televisivo, el problema principal de la comunicación consiste en saber si se han cumplido las condiciones de recepción: ¿tiene quién escucha el código para decodificar lo que estoy diciendo? Cuando se emite una «idea preconcebida», es como si eso ya se hubiera hecho; el problema está resuelto. La comunicación es instantánea porque, en un sentido, no existe. O es solo aparente. El intercambio de «ideas preconcebidas» es una comunicación sin más contenido que el propio hecho de la comunicación. Las «ideas preconcebidas», que desempeñan un papel fundamental en la conversación cotidiana, tienen la virtud de que todo el mundo puede recibirlas, y además instantáneamente: por su banalidad, son comunes al emisor y al receptor. Y, al contrario, el pensamiento es, por definición, subversivo: para empezar a desbaratar las «ideas preconcebidas» y luego tiene que demostrar las propias”29

Y creo que ahí esta la clave: el tiempo en tv es veloz y corre detrás de una economía salvaje. En tv no es posible perder plata, cada segundo está destinado a ganar audiencia que atraiga inversores que paguen los costos y dejen ganancias. La tv es el capitalismo más salvaje. Compite sin piedad y no se detiene a mirar atrás. Solo permanecen en ella quienes sean capaces de vender más. A la tv le importa solo la tv. Le importa la cultura, si la cultura atrae mucha audiencia. Le importa el deporte, si el deporte trae televidentes. Le importan las noticias, si son capaces de mantener al público mirando. ¿Y qué le importa de las mujeres? Sin dudas le importan los CF, porque esos cuerpos son capaces de mantener y aumentar la audiencia televisiva.

\footnotetext{
${ }^{29}$ Bourdieu, Pierre. Sobre la televisión. Barcelona. Editorial Anagrama S.A. 1997
} 
No hay una dimensión más cultural de la tv ni tampoco una neo televisión ni una paleo televisión como algunos formulan. Hay un mercado, una industria televisiva que se transforma a partir de sus clientes, los televidentes, en su búsqueda de una cada de vez mayor audiencia. De manera inteligente busca que es lo que llama la atención. Arriesga, intuye, se equivoca y acierta pero en ningún momento pierde su objetivo, ganar dinero. La tv seduce a los televidentes ese es su negocio. Pero sufre en su trabajo cotidiano de coerción económica, nada es librado al azar, nadie es libre en tv.

Formar, educar y crecer culturalmente son cuestiones ajenas a esta industria, salvo que convoquen grandes audiencias. En la sociedad post disciplinada en que vivimos la tv es una de las más importantes industrias centrada en producir y administrar los deseos de los televidentes. Busca continuamente cuales son esos deseos, los ideales, los caprichos, las esperanzas de la gente para invitarlas a propuestas seductoras. No crea nuestros deseos, ellos son nuestros pero si los afirma, los agranda. Nos muestra en pantalla gigante ese chocolate que todos quieren comer. Tienta una y otra vez $i$ Y hay algún deseo más primitivo en todos los sentidos de la palabra que el cuerpo de una mujer? La tv entonces sabrá disfrazar estos CF según el target de televidentes: en la franja de la tarde CF vestidos de madres, de amas de casas, de jóvenes que trabajan y se encargan de su casa. En la franja de la noche serán jóvenes de poca ropa, vestidas de amantes, quienes venderán seducción y disponibilidad sexual.

CF capaces de captar rating para una vez que los televidentes estén ahí se los venda, se los seduzca con productos del mercado, productos al alcance de sus manos.

Sin embargo Sartori dice no interesarse por la televisión de espectáculos sino por aquella que forma opinión ¿pero la televisión espectáculo no forma opinión, no marca tendencias? Creo que si. Si durante todo el día los CF presentan grandes volúmenes de pecho ¿Qué sentirán las mujeres de pequeños pechos? ¿Se sentirán incluidas, legitimas? La tv espectáculo difunde mensajes y dice su opinión al respecto. Tal vez a Sartori, como hombre blanco europeo e incluido no le interese, a nosotros sí. 


\section{El Rating}

La industria televisiva se mide por el rating que expresa la población promedio que mira un programa o un canal durante cada minuto de su emisión. Es un indicador básico de audiencia que relaciona la cantidad de audiencia, ya sean personas u hogares, con el tiempo de exposición al medio.

Y se ha convertido en el indicador de éxito de los programas. Esto es usado para vender publicidades, se mide cantidad de gente, de hogares y el target de cada uno.

Los cinco canales de aire registrados mostraron: un programa de ficción, absolutamente tradicional como lo fue la novela mexicana. Tres programas de noticias de espectáculos y un programa de interés general. Por lo tanto las propuestas de los cinco son bastantes similares ¿Cuál de ellas tienen mayor cantidad de público? "Este es el show” del canal 13 con un promedio de 9 puntos de rating es el programa más visto en esta franja horaria; seguido por "El triunfo del amor" telenovela mexica del canal 9. Y el de menor público es el programa de interés general de la Tv Publica $^{30}$ con un promedio de 1,7 puntos.

Por lo tanto en esta franja horaria hay un solo programa con una dimensión que pretende ser más cultural y es el de menor audiencia. En cambio los otros son entretenidos, todo en ellos es liviano, ágil, gracioso o ficción pura. Son en parte una realidad inventada, peleas, amores, rencores, odios. Es la televisión espectáculo que nombra Sartori.

Si se analiza este universo de televisión espectáculo se observa que en este horario es la de mayor poder. Sin embargo el segundo programa mas visto es la telenovela mexicana. Aquí nos detenemos para retomar el CF. Porque en esta telenovela los CF cambia en sus formas y sus roles ¿Hay punto de unión entre estos CF? La unión que encontramos es el rol que juegan, en la novela las mujeres trabajan y son capaces de liderar pero terminan anhelando y obedeciendo el mandato masculino. Siendo a la vez el objeto de deseo de hombres que sueñan con poseerlas. Mujeres signadas por las desgracias y que el rol que más desean

\footnotetext{
30 Según datos tomados de IBOPE durante los días que se realizaron las observaciones. http://www.ibope.com.ar/ibope/wp/programacion-por-canal
} 
jugar es el de madres. Entonces esta telenovela no es más que la vieja historia de la cenicienta que termina casada con el príncipe rubio y criando sus hijos y los de él.

Entonces entre las voluptuosas mujeres de los canales de mayor audiencia y esta cenicienta volvemos, drásticamente, al viejo rol femenino. Y este es el punto de unión.

Entre las fuerzas del campo televisivo que por un lado son económicas y por el otro simbólicas, los CF se revisten de lo necesario para captar audiencia: pechos, cabellos rubios, pieles blancas y el rol de débil y subordinada. Empleadas perfectas de una industria atravesada por el exitismo.

Sin embargo nos preguntamos y queda abierta la respuesta. Si la ficción de este horario tuviera como eje una mujer independiente económicamente y simbólicamente o que la historia girara en torno a cuestiones inherentes a la muerte, a la libertad, al trabajo ¿Qué rating tendría? ¿Es necesario que la ficción sea una cenicienta? Pero a la vez si no hay una opción diferente ¿los televidentes seremos capaces de apagar la tv? 


\section{Las tensiones}

Para finalizar esta investigación señalaremos las tensiones encontradas entre la televisión, el cuerpo femenino y las mujeres.

La tensión de la norma

Hay mujeres dentro y fuera de la tv. Un modelo hegemónico atraviesa a todas aquellas que están incluidas o pretenden ser incluidas en la tv argentina, son blancas, europeas, jóvenes, delgadas, poco musculosas, de pechos grandes, cabellos lacios y rubias; que hablan poco y en tonos moderados. Heterosexuales, trabajadoras asalariadas, que se muestran como sujetos eróticos y en roles de menor jerarquía con respecto a sus compañeros varones. Este modelo establece una norma en las mujeres que las coloca en tensión con el resto de mujeres fuera del medio.

Los CF televisivos marcan una diferencia estética e imponen una belleza que en las calles es difícil de encontrar. Sin embargo marcan la tendencia, invitan a copiar un estilo frívolo, europeizado. Una moda que en este momento no acompaña batallas sociales ni revoluciones sexuales, ni grupos emergentes. Una moda que parece solo ocuparse de la belleza femenina cuando solo es funcional a las estructuras sociales de un patriarcado. Estructuras donde a partir del hecho biológico de la composición cromosómica o anatómica, se levanta y se sostiene la construcción cultural que distingue lo masculino de lo femenino siempre de una manera jerárquica. Este disvalor de lo femenino se advirtió a lo largo de todo el trabajo de observación, por ejemplo se repiten los CF que acompañan y/o que complementan a las figuras centrales; se destacan las partes de los CF que seducen a otros, sobre aquellas que son centrales para el placer femenino; es notable la exigencia, aunque no sea admitida públicamente, de responder a un determinado estilo de cuerpo en sus formas, su edad, sus movimientos, su vestuario ${ }^{31}$ sin importar el trabajo que se desempeñe delante de las cámaras. También se destaca la perspectiva victimista ${ }^{32}$ como lo resaltamos en el ejemplo de Susana Gimenez y en las publicidades que para presentar el

\footnotetext{
${ }^{31}$ No es posible ni saludable usar zapatos de 10 o más centímetros. Ni tampoco es igualitario cuando los pares masculinos están simplemente en zapatillas.

32 Badinter, Élisabeth. Hombres Mujeres Como salir del camino equivocado. Buenos Aires. Fondo de cultura económico. 2003
} 
producto caricaturizan a las mujeres o desvalorizan sus capacidades: no saben limpiar, ni lavar, ni poner una simple curita.

Por lo tanto estos CF parecen existir según una escala dominada por la mirada y el deseo masculino. Y esta escala los regula, los normaliza. Cuanto más parecido al modelo más veces lo veremos, más notorio y más famoso. Cuanto menos parecido menos veces lo veremos, por lo tanto más ignorado será.

\section{La tensión del dolor}

No hay en la televisión argentina un cuerpo femenino pensante, creativo, sensitivo, fuerte sino un cuerpo estático y bello, parecido a una foto que se repite una y otra vez. Y para lograr estas semejanzas es necesaria la intervención tecnológica sobre esos cuerpos. Sin cirugías como la mamoplastía de aumento sería imposible que del total de mujeres observadas el 65,8\% tenga pechos grandes y en los canales de mayor audiencia este porcentaje suba al $90,1 \%$ y al $84,9 \%$

Esta es la segunda tensión que se establece, la tensión del dolor que obliga a las mujeres a convertir al cuerpo en un objeto capaz de transformarse a sí mismo.

Mientras que el uso la píldora da a las mujeres la posibilidad de elegir o no la maternidad, de vivir el placer sexual sin miedo y la anestesia epidural permite los partos sin dolor, en la televisión argentina muestra $\mathrm{CF}$ que se someten al dolor y ponen en riesgo su salud para alcanzar un determinado indicador de perfección física. El camino emprendido décadas atrás daba a los CF autonomía. Las alejaba del dolor, de lo inevitable. Y acercaba la sexualidad y la maternidad solo al deseo. En cambio en la televisión argentina de hoy, la ciencia se utiliza para normalizar CF que sepan atraer miradas. No se habla del dolor que esto causa, ni de las sensaciones que se pierden o se ganan. No se habla de cómo se vuelve a armar el CF desde estos pechos inventados. Desde el dolor los CF televisivos se inscriben en el mercado de consumo, se instalan en el universo de los medios masivos de comunicación que les dará reconocimiento social. 


\section{La tensión rosa}

La historia de amor, la novela romántica recreada en las ficciones de la televisión y representada en la realidad por las famosas botineras ${ }^{33}$ o las actrices y conductoras casadas con productores o empresarios.

Esta historia de amor es la búsqueda del hombre (nunca otra mujer) con quien formar una familia. Pero la búsqueda es en sí misma el objetivo de vida, como si la identidad de las mujeres dependiera de encontrar ese matrimonio. La captura del corazón del otro será el comienzo de una relación amorosa ideal que se prolongara en el tiempo. Una pareja estable no una conquista sexual. Las bodas por televisión, las fotos, el primer hijo todo se presenta como una novela con final feliz. Cuanto más grande y ostentosa sea la celebración mas amor habrá.

La búsqueda de pareja es un proceso activo comprometido con el futuro, que muchas veces se separa de ideas y modos pre existentes porque la misma realidad lo impone: el aumento de la esperanza de vida; la ley de divorcio; la no aceptación pasiva de relaciones extra matrimoniales; la imposibilidad económica de que un solo miembro de la pareja trabaje para mantener a ambos; la posibilidad de planificar el cuándo y cuántos hijos tener. Pero los CF no son un valor de intercambio en las historias de amor modernas. La libertad sexual de las mujeres existe, aunque a veces sea difícil ejercitarla frente a algunas actitudes masculinas Los CF fuera de la televisión intentan renegociar los roles en la pareja, crear nuevas formas de vida, para nuevas parejas que decidan enfrentar juntos el día a día. Sin embargo en la televisión los CF que se muestran como sujetos eróticos son el elemento de conquista de las historias de amor y el triunfo de la historia se cuenta en dólares o euros que permitan ascenso social y económico.

\section{La tensión americana}

Y por último llegamos a la tensión americana. La ausencia de rasgos indo americanos en la televisión argentina nos muestra un país que todavía está decidido a emplear un imperativo de CF que permite solo ciertas identificaciones y excluye y repudia otras. Y aquí si

\footnotetext{
${ }^{33}$ Botinera, se denominan las vedette o modelos que se casan con deportista de primer nivel, logrando un rápido ascenso social y económico
} 
encontramos una gran diferencia entre el producto mexicano (la telenovela) y los productos argentinos. En la telenovela los CF eran indo americanos o cercanos a ello en cambio los argentinos estaban muy alejados. Todavía hoy no entra, en nuestro país, en el concepto de belleza los rasgos indo americanos.

Los CF luchan simplemente por ser incluidos, por estar, por pertenecer a la tv esto es lo importante y no quienes ni por que quedan fuera.

Y tal vez esto si se traslade a las calles argentinas. Estar incluidas en la sociedad argentina como mujeres tal vez sea en estos tiempos y en este país lo más urgente.

Los CF televisivos muestran un espectáculo que puede ser criticado desde muchos puntos pero no deja de ser un espectáculo. Las mujeres en su vida cotidiana viven al parecer en la clandestinidad. Muchas ya no esperan la historia de amor. Muchas viven sus pasiones frenéticamente, seducen para conseguir amor, sexo, pareja y también objetos y beneficios. Definen sus formas con alguna prenda que haya en el ropero. Se sacan el corpiño. Comen, bailan, ríen, trabajan, educan, curan, investigan, deciden, prometen, crean, disputan. Pero al parecer todo en la clandestinidad porque ni la televisión, ni en los medios gráficos las mujeres somos algo más que CF hegemónicos 
Dejaremos en este apartado, a modo de ejemplo, las planillas con las cuales se relevo la información. Las mismas tienen la desprolijidad propia de la tarea. Planilla diaria por programa, ejemplo "Este es el show" canal 13

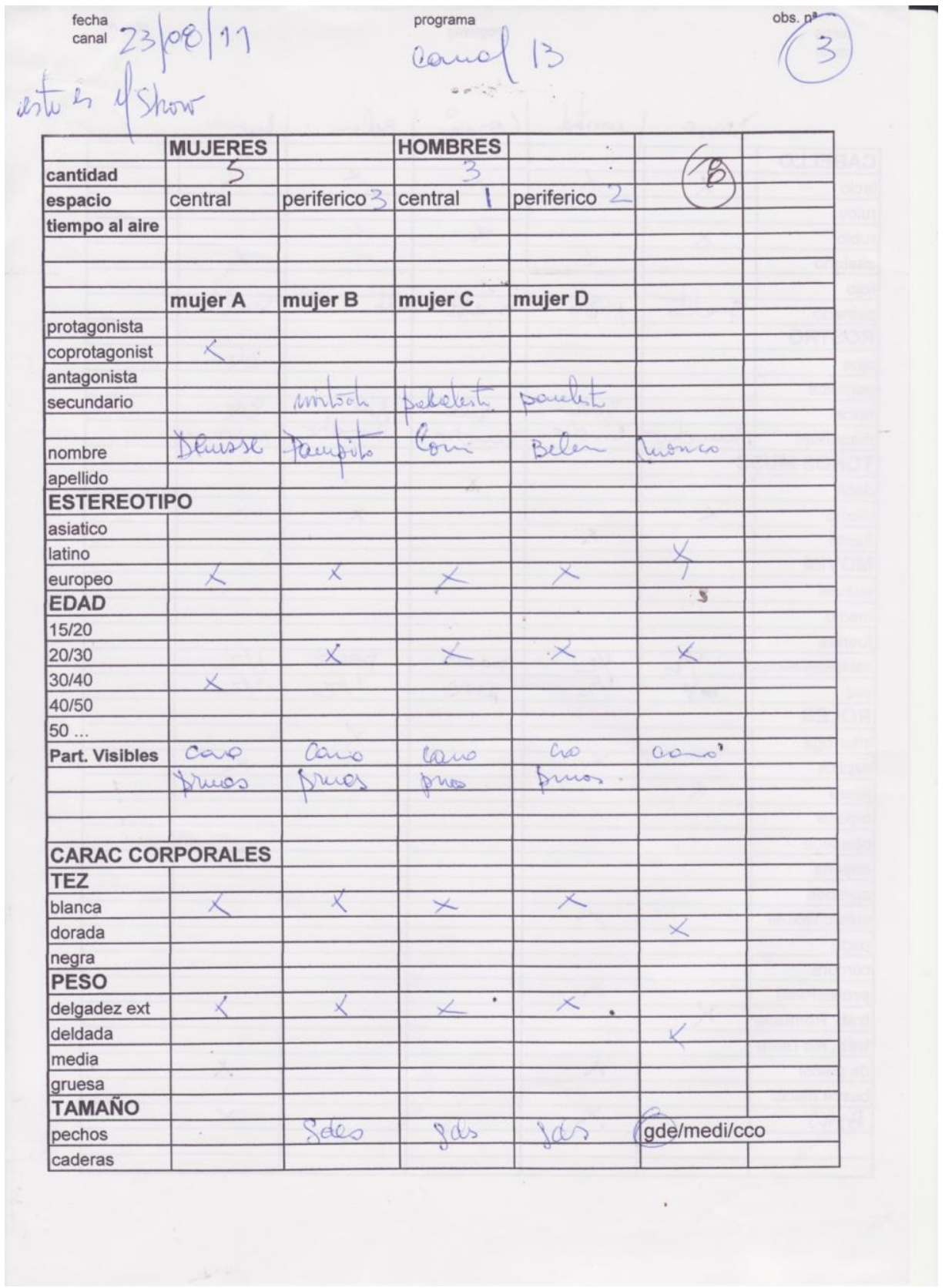




\begin{tabular}{|c|c|c|c|c|c|c|}
\hline fecha & & & programa & & & obs. $n^{a}$ \\
\hline \multicolumn{7}{|l|}{ CABELLO } \\
\hline lacio & X & X & $x$ & $x$ & $x$ & \\
\hline \multicolumn{7}{|l|}{ rulos } \\
\hline rubio & $x$ & & 70 & $<$ & & \\
\hline castaño & & $x$ & & & $x$ & \\
\hline \multicolumn{7}{|l|}{ rojo } \\
\hline peinado & Suelto & AtviDo & suett & weth & Sneet & \\
\hline \multicolumn{7}{|l|}{ ROSTRO } \\
\hline ojos & & & & & fole & \\
\hline \multicolumn{7}{|l|}{ pomulos } \\
\hline boca & & gde & sole & Sde & Selp & \\
\hline maquillaje & Mundor & linos & linchs & linch & wurch - & \\
\hline \multicolumn{7}{|c|}{\begin{tabular}{|l|l|} 
TONOS MUSC \\
\end{tabular}} \\
\hline debil & & & $\lambda$ & $\cdot$ & & \\
\hline medio & $x$ & & & $x$ & $x$ & \\
\hline fuerte & & $x$ & & & & \\
\hline \multicolumn{7}{|l|}{ MOVIM } \\
\hline suaves & & & & & 5 & 5 \\
\hline \multicolumn{7}{|l|}{ medio } \\
\hline \multicolumn{7}{|l|}{ fuertes } \\
\hline \multicolumn{7}{|l|}{ hablamucho/medipoco } \\
\hline voz & hop & $1 / 2$ & ALTS & $1 / 2$ & $1 / 2$ & \\
\hline \multicolumn{7}{|l|}{ ROLES } \\
\hline interroga & & & & $x$ & 1 & \\
\hline explica & & $x$ & & & $x$ & \\
\hline lidera & $x$ & & & & & \\
\hline \multicolumn{7}{|l|}{ ordena } \\
\hline \multicolumn{7}{|l|}{ obedece } \\
\hline \multicolumn{7}{|l|}{ enseña } \\
\hline \multicolumn{7}{|l|}{ aprende } \\
\hline sujeto sexual & & $x$ & & & & \\
\hline \multicolumn{7}{|l|}{ paga } \\
\hline \multicolumn{7}{|l|}{ compra } \\
\hline profesional & & $x$ & & & & \\
\hline trab. Remuner & X & $\cdot$ & & & & \\
\hline \multicolumn{7}{|l|}{ trab. No remu } \\
\hline da placer & & l & & & $x$ & \\
\hline \multicolumn{7}{|l|}{ busca placer } \\
\hline Brois & & $x$ & & & $x$ & \\
\hline & & & & & & \\
\hline & & & & & & \\
\hline & & & & & . & \\
\hline
\end{tabular}


Planilla de resumen final por programa, ejemplo canal 9
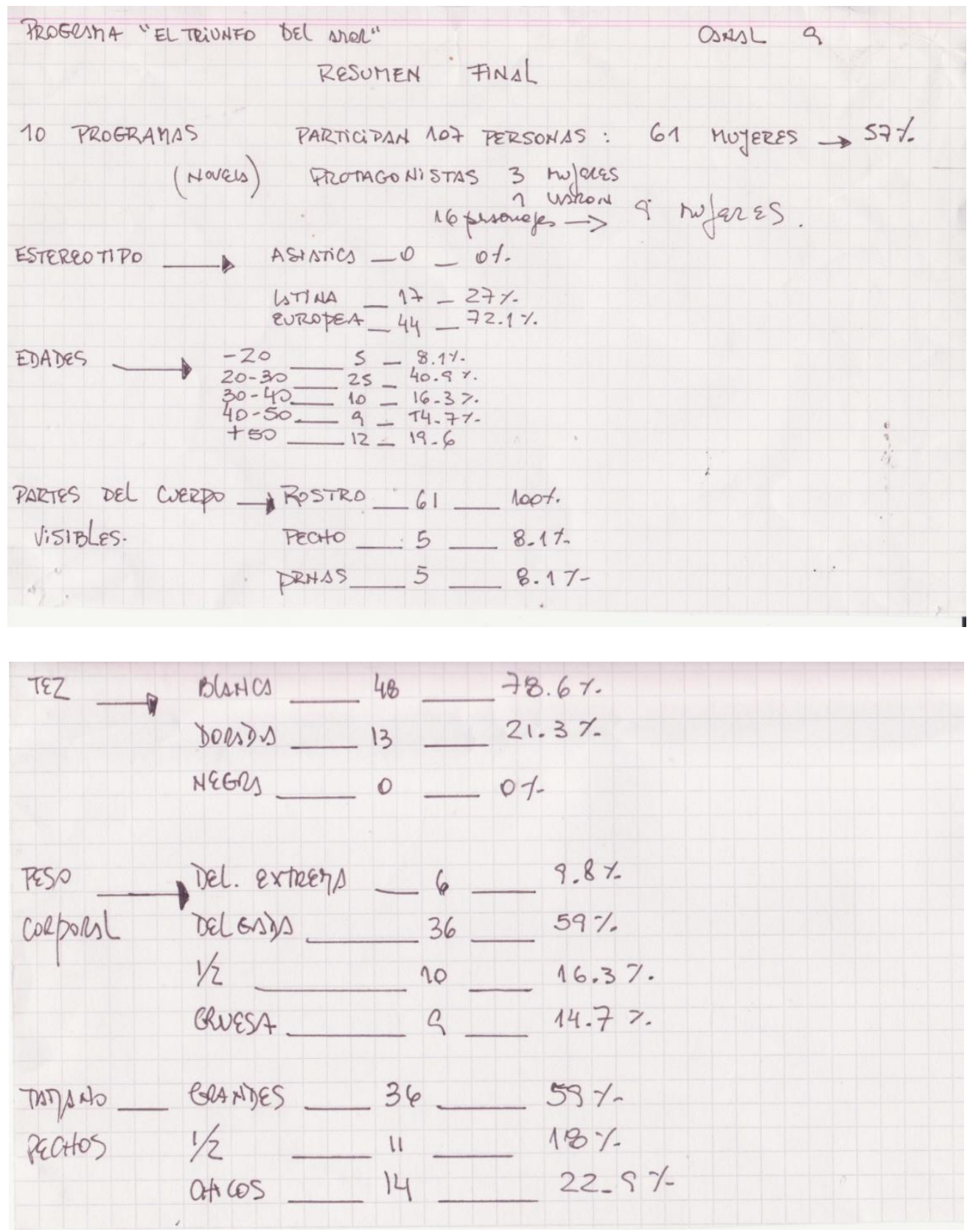


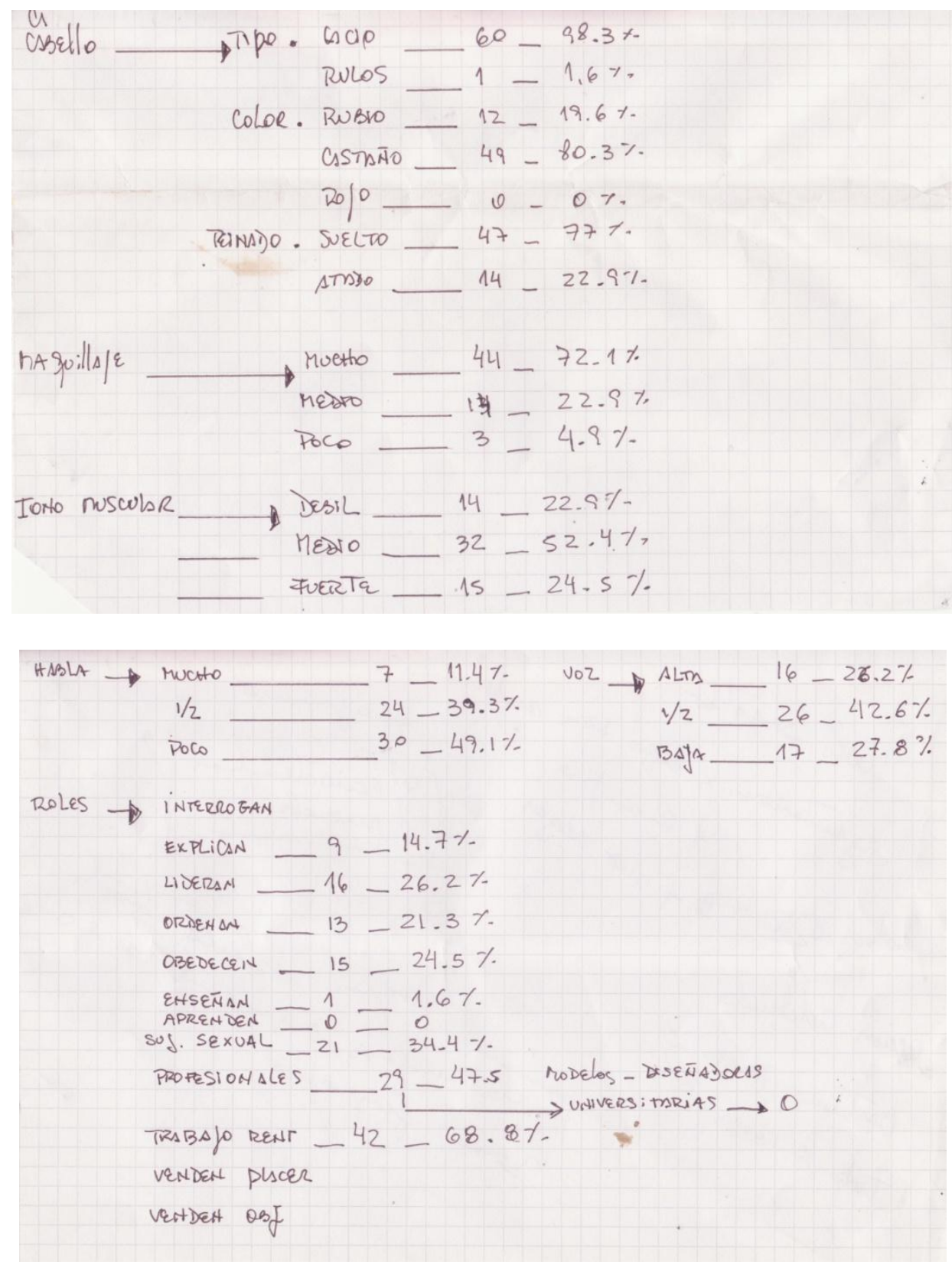




\section{Planilla diaria para publicidades, ejemplo canal 13}

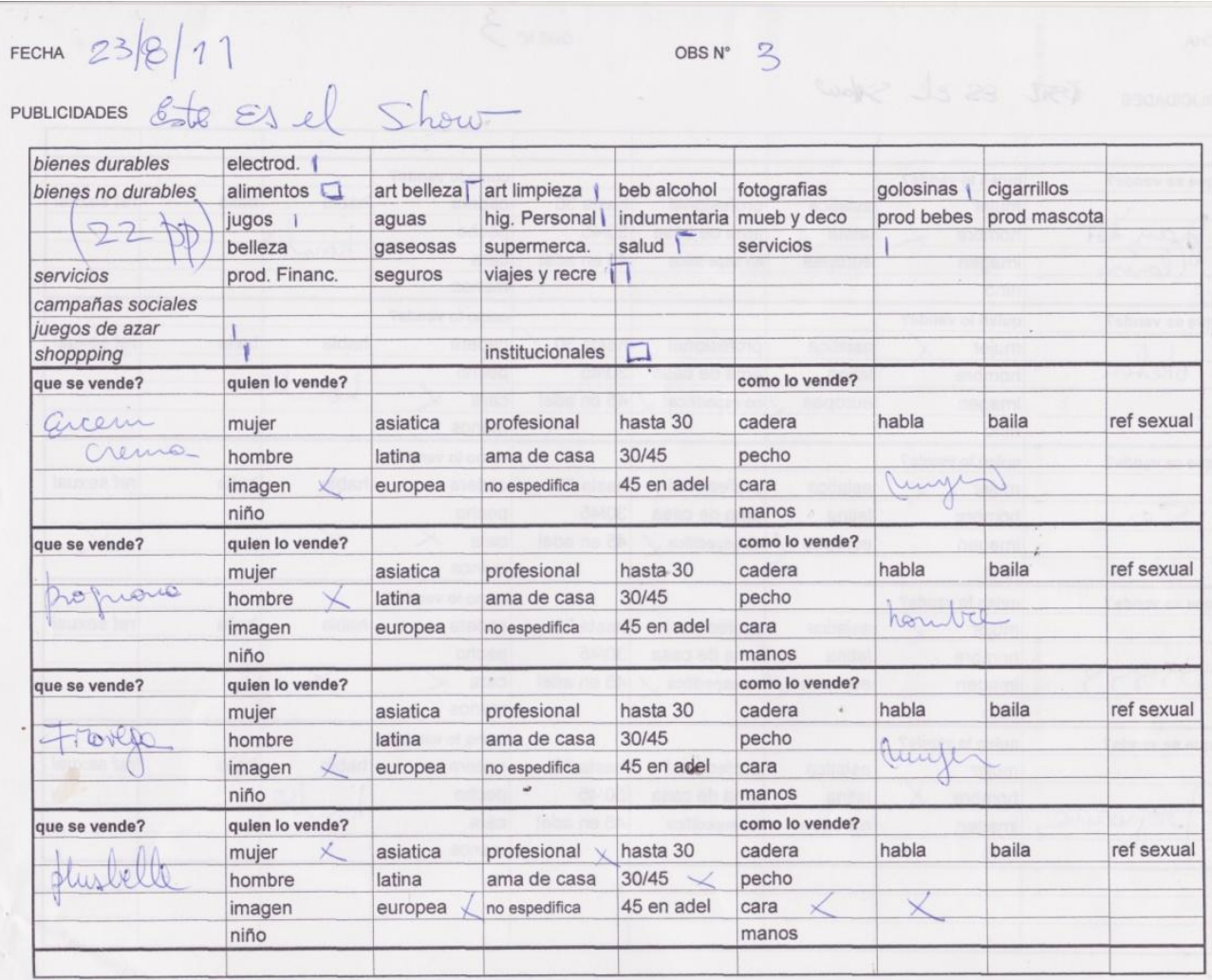

FECHA

OBS $N^{3} 3$

PUBLICIDADES ¿STE es el show

\begin{tabular}{|c|c|c|c|c|c|c|c|c|}
\hline \multirow{2}{*}{ que se vende? } & quien lo vende? & & & & como lo vende? & & & \\
\hline & mujer & asiatica & profesional & hasta 30 & $\begin{array}{l}\text { comolo vender } \\
\text { cadera }\end{array}$ & habla & & \\
\hline han DH & hombre $x$ & latina & ama de casa & $30 / 45$ & pecho & & baila & ref sexual \\
\hline \multirow{2}{*}{ Slam } & imagen & europea & no espedifica & 45 en adel & cara & hor & ᄃ & \\
\hline & nin๊o & & & & manos & & & \\
\hline \multirow[t]{2}{*}{ que se vende? } & quien lo vende? & & & & como lo vende? & & & \\
\hline & mujer & asiatica & profesional & hasta $30<$ & cadera & habla & baila & \\
\hline \multirow[t]{3}{*}{ Breton } & hombre & latina & ama de casa & $30 / 45$ & pecho & & & ref sexual \\
\hline & imagen & europea & no espedifica $\chi$ & 45 en adel & cara & home & e & \\
\hline & niño & & & & manos & & & \\
\hline \multirow{2}{*}{ que se vende? } & quien lo vende? & & & & como lo vende? & & & \\
\hline & mujer & asiatica & profesional & hasta 30 & cadera & habla & baila & \\
\hline \multirow[t]{3}{*}{ Ser } & hombre & latina & ama de casa & $30 / 45$ & pecho & & & ref sexual \\
\hline & imagen & europea & no espedifica $<$ & 45 en adel & cara X & $<$ & & \\
\hline & niño & & & . & manos & & & \\
\hline \multirow[t]{2}{*}{ que se vende? } & quien lo vende? & & . & & como lo vende? & & & \\
\hline & mujer & asiatica & profesional & hasta $30 \mathrm{~K}$ & cadera & habla & baila & \\
\hline \multirow{3}{*}{39998} & hombre & latina & ama de casa & $30 / 45$ & pecho & & & ref sexual \\
\hline & imagen & europea : & no espedifica $x$ & 45 en adel & cara $<$ & $x$ & & \\
\hline & niño & & & & manos. & & & . \\
\hline \multirow[t]{3}{*}{ que se vende? } & quien lo vende? & & & & como lo vende? & & & \\
\hline & mujer & asiatica & profesional & haste 30 & cadera & habla & baila & \\
\hline & hombre X & latina & ăma de casa & $30 / 45$ & pecho & & & ref sexual \\
\hline Difracure & imagen & europea & no espedifica & 45 en adel & cara & 5 & & \\
\hline & niño & & & & manos & & & \\
\hline & & & & & & & & \\
\hline & & & 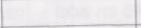 & & & & & \\
\hline & & & & & & & & \\
\hline
\end{tabular}


Planilla Publicidades resumen final por canal, ejemplo America Tv

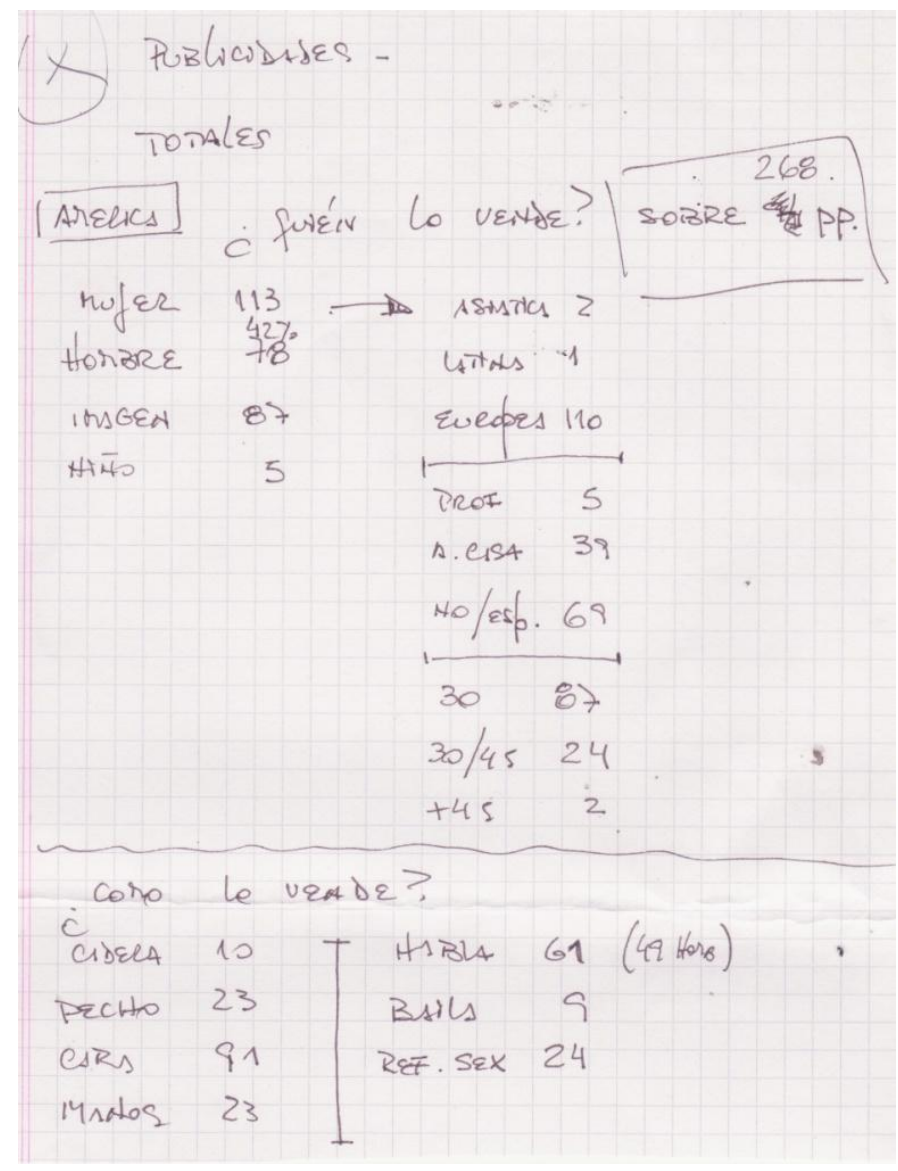

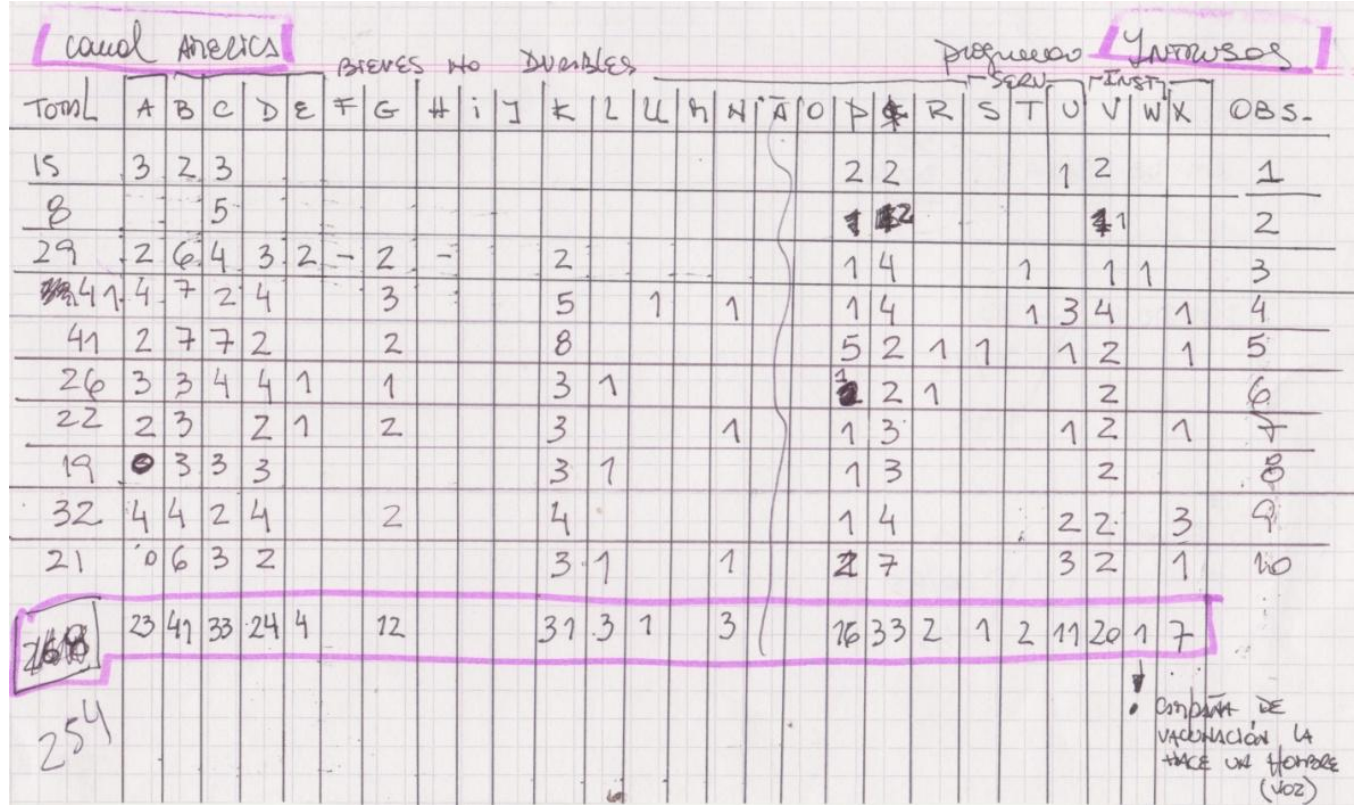


Para tener un análisis más completo este apartado hace una descripción de los cinco programas que han sido observados en la franja horaria elegida. Ellos fueron:

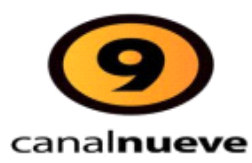

"El triunfo del amor", Telenovela mexicana en la cual participan durante todas las observaciones un total de 107 personas entre los cuales el 57\% fueron mujeres.

Los roles protagónicos son de 2 mujeres y un hombre. El antagónico es una mujer y los co protagónicos son de 3 hombres y una mujer.

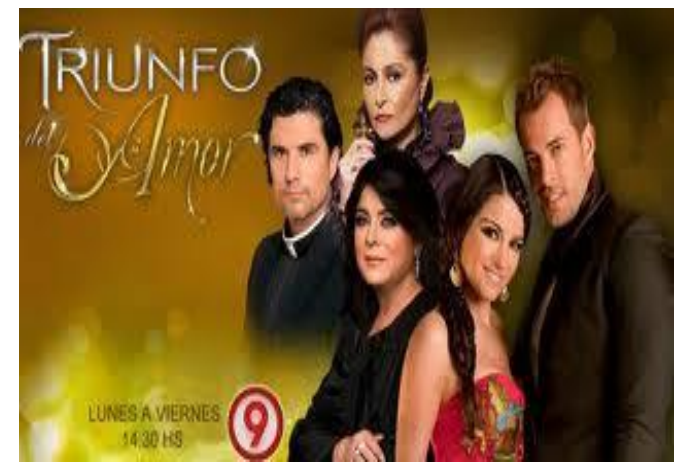

La historia transcurre en México y tiene como lugar principal una empresa de modas donde trabajan la mayoría de los personajes. Dos jóvenes que se enamoran pero al mismo tiempo y por compromisos anteriores deciden no estar juntos. Paralelamente ella no sabe quiénes son sus padres y él no conoce a su madre ni su historia verdadera. Juntos tendrán un hijo al cual ella intentará ocultarle su origen. La pareja central estará rodeada de personajes con malas intenciones a los cuales ellos creerán de manera totalmente inocente cada vez que estos interfieran en sus vidas. Paralelamente a esta historia central hay otra historia, las dos mujeres maduras (la madre del joven y su eterna competidora) en la cual todo será una lucha por esclarecer o no sus historias y por el poder de una empresa.

En esta novela las mujeres todas trabajan, sus profesiones y oficios son: modelos, directivas de una empresa de moda, secretarias, administrativas, monjas, mucamas. No hay ninguna universitaria. Se hace referencia a los trabajos como una presentación de las personas o por los uniformes (de mucama), no las vemos trabajar, solo están en sus lugares de trabajo. Muy de vez en cuando hubo escenas de las modelos en algún desfile o sesión de fotos. No notamos pasión ni dificultades en cuestiones laborales. El trabajo y sus profesiones son 
excusas de lugares y de encuentros para el desarrollo de la historia, no es central sino un soporte y los personajes no muestran estas profesiones como algo central en sus vidas.

El poder esta ejercido por las dos protagonistas más maduras y el objetivo de ambas es el poder en la empresa que una de ellas forjo. Ellas son poderosas en su trabajo y cabeza de familia lo que las convierte en matriarcas.

Forman familias ensambladas o mono parentales. En lo que respecta a su sexualidad son todas hetosexuales y no queda claro si concretan sus relaciones sexualmente. Son engañadas y manipuladas constantemente y engañan y manipulan en cada escena. Pero no se las ve sexualmente activas, si amorosamente.

Ocultar la paternidad por opción o por desconocimiento es una constante en la historia, llegando al punto de que una de sus protagonistas mujeres no sabe quién es su hija a quien ve a diario. Parecería que la planificación familiar no formara parte de sus universos, no existieran métodos anticonceptivos y las parejas tuvieran como única función u objeto tener hijos. Sin embargo los únicos casos en que se ve la planificación de un embarazo es exclusivamente para manipular alguna situación (presionar sobre un casamiento por ejemplo)

El amor en esta historia es un amor único, no hay dos posibilidades de enamorarse. Un único amor que se persigue toda la vida y al que hay que contrariar o por el que hay que luchar. Nada es fácil en los amores de esta novela, nadie es feliz en las cuestiones del amor de manera rápida o simple. Y quienes deciden no obedecer ese impulso amoroso son personajes tristes y angustiados.

La venganza no es una posibilidad en la vida de estos personajes es una misión. Algunos solo viven para vengarse a cualquier costo, como si no fuera imposible seguir adelante con sus vidas.

La locura o la muerte son los caminos para quienes no encontraron el amor correspondido. Y la iglesia como destino para los que no logran tener una vida moralmente aceptable, representados en el personaje del cura que no sabe que tiene una hija, que no sabe que su madre secuestro de pequeña. 
Aquí las mujeres mandan. Luchan obstinadamente por el poder y por el dinero. Mandan a sus hijos, a sus parejas, a sus empleados. Son expertas en lo que hacen. Trabajan por el dinero y lo hacen a destajo. Las mujeres de clase alta tienen personal doméstico a su cargo. En la clase baja el trabajo es dentro y fuera de la casa. Siempre en roles muy tradicionales las mujeres tienen todo tipo de emprendimientos, cocinan, planchan, lavan, cosen, cuidan niños, enfermos, ancianos. Son jefas de hogar.

El rol de madre es ejercido por casi todas las mujeres de la telenovela y es tomado como algo muy positivo. Las hay de todo tipo abnegadas, amorosas, capaces de criar niños que no sean de su sangre, dominantes, despiadadas, abandonicas pero cualquiera sea el caso tienen el control de sus hijos aunque estos sean maduros.

También encontramos mujeres en un rol de sometimiento ante un varón a través de la violencia sicológica y física aún las mujeres más poderosas muestran como pasan por este rol.

No hemos notado en estos personajes femeninos roles de objeto erótico, no se exhiben ofreciendo solo placer, si en cambio son objeto de deseo amoroso. Para explicar mas esta cuestión deberíamos decir que en esta telenovela hay relaciones donde la mujer es objeto de deseo pero claramente un deseo amoroso, un enamoramiento idílico con intenciones de formar una familia, de cuidar a la mujer como si esta fuera un objeto de absoluta fragilidad, o sea, un rol absolutamente tradicional.

Las mujeres que actúan en esta novela son en su mayoría de un estereotipo latino. Morochas, voluptuosas, de ojos marrones con miradas seductoras. Caderas anchas, pieles cobrizas. Están vestidas de manera muy formal comparando con la moda argentina y peinadas de igual manera. 


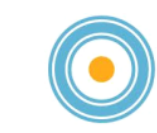

TV Pública

"Vivo en Argentina", es un programa de entretenimiento o de interés general que muestra cada semana un lugar distinto del país. Tiene una parte en estudio con dos conductores, un hombre y una mujer, que están en la capital del país. Y otra parte de exteriores conducida por un hombre que es

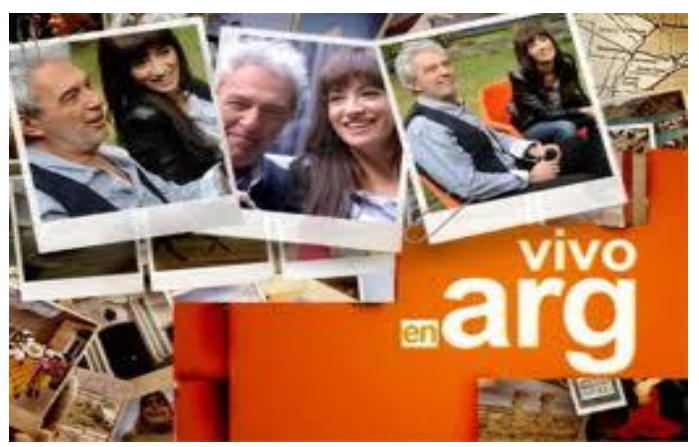
quien se desplaza por el país haciendo notas "locales".

Entonces el programa está formado por 5 personas, 2 de ellas son mujeres, son el $40 \%$ del equipo. Hay un conductor y una co-conductora. Dos cronistas, hombre y mujer y un notero que es quien hace las notas desde el interior del país (¿habrá exterior del país, cuál será?). Cada día hay uno o más invitados en el piso y en las notas, por lo tanto en el total de nuestras observaciones hubo 62 personas entre las cuales el $66.1 \%$ eran mujeres.

La pareja que protagoniza el programa tiene matices tradicionales en el sentido que en esta pareja él es quien domina la escena y ella acompaña. Él conduce, sabe, conoce a los invitados, les toma examen mientras ella demuestra que no sabe muchas cuestiones, se asombra, habla muchísimo menos que su compañero. Mientras él esta vestido de manera casual ella siempre está producida de tacos y peluquería.

La pareja secundaria, presenta notas de los alrededores de la ciudad. Están vestidos muy de sport con poca producción. Cuando aparecen juntos tienen una dinámica muy pareja que no demuestra diferencias en ellos.

Carla Conte es la co-conductora de este programa; tiene 32 años, secundario completo. Estudio danzas (no podemos decir cuánto tiempo) y comenzó su carrera en la tv participando en un video clip de una banda de rock. Trabaja en la televisión desde el 2004 como conductora o co conductora en programas de juegos y entretenimientos. Es muy delgada (la hemos colocado en nuestra planilla como delgadez extrema) morocha, de pelo 
lacio y ojos marrones. Con busto abundante. Muestra su cuerpo de manera sexi, es heterosexual. Maquillada y vestida con lo que marca la moda se muestra como una mujer moderna. Es muy conocida por los televidentes por lo que sabemos que tiene un niño muy pequeño y que está casada. Su rol es de acompañar al conductor. Sin profundidades ni cuestionamientos, siempre liviana en sus dichos y preguntas juega un rol entre divertido, tonto y sorprendido. No enseña ni muestra nada. No dirige ni conduce. No muestra en este programa su cuerpo como objeto de deseo.

Angela Lerena es la otra mujer en el programa. Ella estudio periodismo deportivo y curso la carrera de comunicación en la UBA, tiene una amplia trayectoria en programas deportivos y es conocida por su labor en ellos como una de las poquísimas mujeres que hablan de futbol en nuestro país. Sin embargo en este programa hace notas de interés general que ella misma produce y lleva adelante. Enérgica, con un buen vocabulario demuestra su preparación intelectual. Es delgada, rubia de pelo lacio no dice su edad calculamos entre 30 y 35 años. Su vestuario es casual, lo mismo que su peinado. Su imagen nada tiene que ver con lo sensual. Tiene el rol de mostrar lugares y cosas que investiga, pregunta, toma desafíos, hace bromas. Conduce sus notas, saca conclusiones y da consejos.

Otras mujeres en el programa que participan solo una vez como invitadas. El periodo que nos toco observar estas mujeres eran generalmente europeas, algunas incluso habían nacido allí. Todas tenían en particular alguna actividad que desarrollaban bailaban tango, eran chacareras, cantantes. Otras mujeres aparecen en el móvil desde el "interior” ahí muchas se muestran en actividades tradicionales de cada zona. Un caso particular fue en un plaza el notero busca a alguien para preguntar una cuestión menor, aparece entonces una joven mujer con una niña y dice que es bióloga investigadora cuenta a que se dedica y la respuesta del notero es: - estas bárbara no pareces bióloga! 
AMERICA

"Intrusos", es un programa de entretenimiento en la cual trabajan diariamente frente a la pantalla un total de 7 personas entre los cuales hay 3 mujeres o sea el $42 \%$. Cada día hay invitados en el piso y algunas notas en exteriores por lo que el

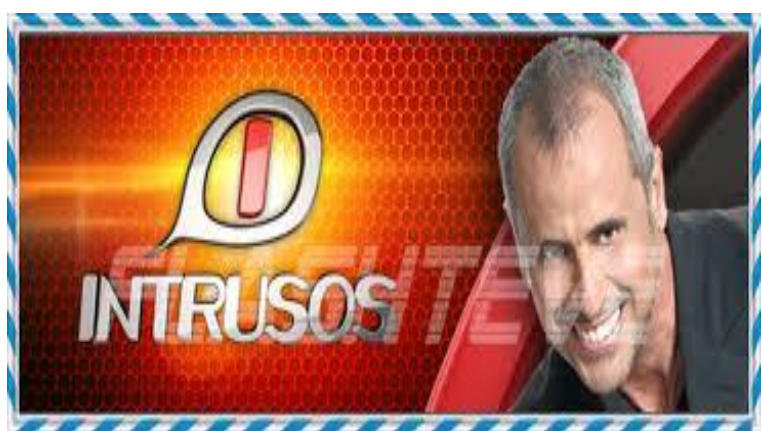
total de mujeres que vemos diariamente es del $57 \%$ en este canal a esta hora.

El rol protagónico es de un hombre como el conductor del programa. Los demás son panelistas 3 mujeres y 3 hombres.

El programa trata sobre lo que sucede con quienes trabajan en la tv, los programas y sus sucesos. Pero mayoritariamente se vierten opiniones sobre la vida privada de las personas de la llamada farándula local. Se habla de "chimentos" ya que no solo se dice lo que sucede con ellos sino que se vierten opiniones, se confronta y se buscan testigos, pequeñas investigaciones acerca de que dijeron, que hicieron, que les paso. Se intenta saber hecho, sentimientos, dificultades y miserias de los mediáticos ${ }^{34}$.

Las mujeres fijas en este programa son: Marcela Tauro, Cora Debarbieri y Marcela Baños.

Marcela tauro es periodista de espectáculos, la más conocida de todas, es la $3^{\mathrm{a}}$ en este programa, lidera la voz femenina del mismo ya que lleva 8 años trabajando ahí. Es de estereotipo europeo, blanca de 46 años entre de peso medio y pechos pequeños tal vez sea esta la razón de que usa pocos escotes y mas polleras. Permanece sentada y se mueve bastante a pesar de esto. Habla en voz alta y participa dando noticias, opiniones o haciendo preguntas. Tiene tensiones con algunos invitados que sirven para hacer mas entretenidas las

\footnotetext{
${ }^{34}$ Mediáticos: usaremos este término para todas aquellas personas que siendo desconocidas a nivel popular comienzan a trabajar a diario en la televisión por algún suceso como por ejemplo: participar en un concurso, estar en pareja con alguien de la tv, ser amante de algún famoso o tener algún alternado televisivo. Ser mediático no implica ninguna formación especial por lo tanto no podemos decir que son artistas ni profesionales de ningún tipo, aunque por supuesto, no quiere decir que no lo sean.
} 
notas con lo cual su rol puede ser de crear controversias, opina como opinaríamos la mayoría de gente que no somos mediáticos, creemos que intenta usar el sentido común y no filtrar sus percepciones. A veces lidera el grupo de panelistas, hace chistes y bromas a sus compañeros o entrevistados. No se muestra como un objeto de deseo. Es heterosexual, está casada y tiene un hijo pequeño.

Cora Debarbieri es periodista gráfica, trabajo en la redacción de la revistas de actualidad. Parece tener menos de 30 años, de estereotipo europeo, blanca, delgada con un tono muscular débil y pechos medianos. Es rubia de pelo lacio muy maquillada y vestida mayormente de noche permanece sentada con las piernas cruzadas y casi sin moverse. Habla poco y en voz baja. Su rol es de panelista, pregunta y opina pero lo hace poco. No se exhibe como un objeto de deseo, nunca lidera. Es heterosexual, no tiene hijos.

Marcela baños es locutora recibida en el ICER. Fue la cara femenina de Pasión tropical (programa de cumbia muy conocido). Su participación es muy pasiva, sus comentarios son pocos. Habla es voz de media a baja. Siempre está sentada por lo que sus movimientos son solo de manos y su cuerpo está quieto cruzado de piernas. Su rol es de opinar y preguntar. No se muestra como un objeto de placer. Y casi no la nombran en el programa por lo que fue muy difícil saber como se llamaba. Es de estereotipo europeo, de 37 años que no aparenta, tez blanca, delgada de grandes pechos con un tono muscular bueno, es morocha de pelo lacio. Siempre muy maquillada y con polleras. Heterosexual, soltera y sin hijos. 


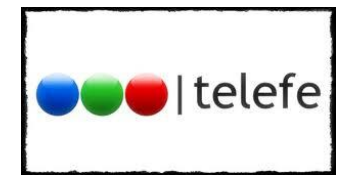

“Zapping diario", programa de entretenimiento conducido por una pareja más los comentarios de tres panelistas. En total son 5 personas, dos de ellas son mujeres. Con los invitados diarios el número de personas observadas ascendió a 102 de las cuales el $69.6 \%$ eran mujeres.

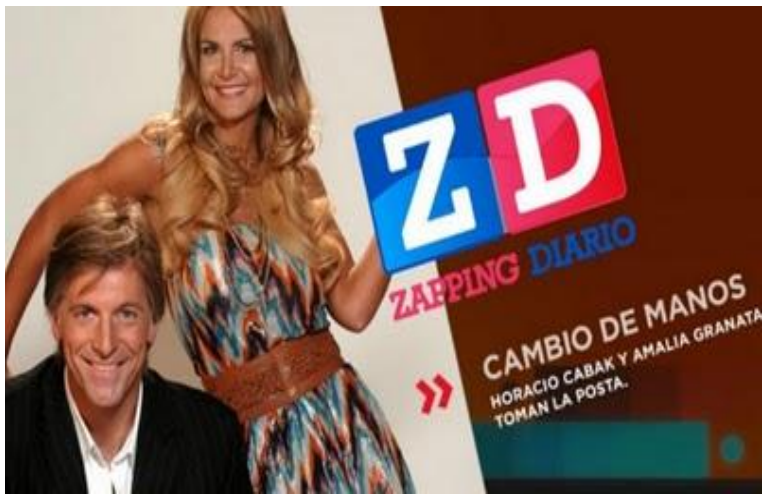
Los temas que se tratan son nuevamente la farándula, los sucesos en sus vidas y el acontecer en la televisión. La vida de los mediáticos es el tema de conversación y de investigación. La actualidad de la televisión

La pareja que conduce es asimétrica, él lleva la conducción con mayor habilidad y oficio. Ella acompaña tímidamente, Amalia Granata es la co conductora de 30 años, modelo se hace famosa en el ambiente de la tv por hacer pública una relación sexual con un cantante ingles y vuelve a ser noticia cuando se casa con un jugador de futbol por lo que se la conoce como "botinera". A partir de eso comienza a tener participación en notas y programas de "chimentos". Es rubia de pelo lacio, delgada, de grandes pechos y aspecto moderno en su vestuario. En este programa habla muy poco y sus opiniones parecen ser siempre desde sus sentimientos. Sin comentarios profundos ni opiniones precisas todo es vago y lejano en esta rubia que si intenta no ser blanco de los chistes de su pareja en la conducción. Su rol es el de acompañar al conductor, darle los pie en el texto y reírse de sus chistes.

Sin embargo Amalia es conocida también por entablar una demanda al padre de su hija por alimentos argumentando muy sólidamente este hecho frente a las cámaras. Durante el año pasado discute con solidez y coherencia frente al jefe de Gabinete de ministro, Anibal Fernandez diciendo: -"Sólo soy una 'laburanta' que vive la realidad que vivimos todos los argentinos. A mí nadie me dice lo que tengo que decir." "No vivo en una burbuja. Yo soy el sostén de mi casa, pago los impuestos, tengo una empleada a mi cargo, una hija a la que 
le pago el jardín y la obra social. Vivo la realidad que vivimos todos y pretendía que él, como funcionario, escuche al pueblo". Como si tuviera dos caras Amalia es capaz de enfrentar y lidiar con sus derechos y a la vez ser la rubia que acompaña fundiéndose en la frívola vida de los mediáticos. Todo por supuesto frente a cámara.

La otra mujer del programa es Laura Ubfal, una periodista de espectáculos de aproximadamente 54 años. Su rol en el programa es de aportar alguna opinión o novedad en las notas que se están mostrando. No hace notas pero sí parece saber más de lo que el público y los conductores saben. Estudio periodismo y tiene un diario sobre noticias de la farándula y el espectáculo en la web. Rubia de pelo lacio su participación no sobresale. En cambio se distingue por su edad y su peso corporal aportando una diferencia a la media de nuestra planilla.

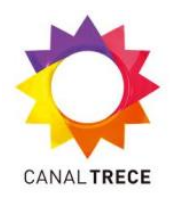

"Este es el show", programa de entretenimiento que habla de lo que sucede en los programas del mismo canal y de la misma productora. Aquí se revisan los hechos más notables de los programas centrales en el horario nocturno, hablan los protagonistas $\mathrm{y}$ como es costumbre se pelean, se critican, se

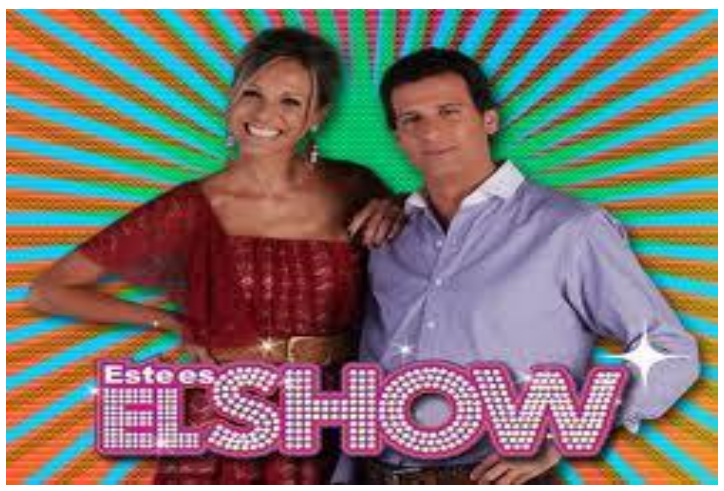
amigan y etc. Nuevamente la vida de los mediáticos en la pantalla. Intenta ser un programa con humor, su propaganda dice "alegran tus tardes"35

\footnotetext{
${ }^{35}$ Aquí notamos una suposición acerca que las tardes son aburridas y es bueno alegrarse. No podemos dejar de pensar en que si tradicionalmente las mujeres son quienes permanecen en sus hogares esta frase se refiere a esas mujeres, las amas de casas. $Y$ supone que ellas están tristes ¿tristes por estar en sus casas? ¿aburridas de estar encerradas? ¿encerradas sin compañía masculina? ¿se aburren o entristecen por la ausencia de ese varón?
} 
En la producción y dirección trabajan 7 hombres y ninguna mujer. Participan delante de la pantalla 10 personas, 6 son mujeres. Sumando a los invitados diarios han participado 79 personas de las cuales el $67 \%$ fueron mujeres.

La conducción está a cargo de dos personas un hombre y una mujer. Ella figura segunda.

Esta mujer, Denise Dumas ha dado con su participación un giro importante al programa; le aporta calidez, humor, naturalidad. A la par de su compañero en cuanto a la conducción, en las preguntas a los entrevistados imprime un toque personal que contrasta con la agresividad de su co conductor. Es notable como corporalmente ella se coloca a la par de él y lo toca con gesto de compañerismo, en las fotos generalmente ella apoya su mano en el hombro de él o pasa el abrazo por detrás en un abrazo. No se encuentran fotos en situación inversa.

Es modelo, tuvo algunas participaciones como actriz. Tiene 36 años, estudio en un exclusivo colegio ingles y luego estudio teatro e hizo modelaje. Es muy alta, rubia de pelo lacio, muy delgada y poco musculosa. Siempre vestida muy a la moda.

Otras mujeres aparecen en este programa: Connie Ansaldi, Belen Francese, Marcela Coronel, Paula Varela.

Marcela Coronel es una periodista egresada del Circulo de Prensa realizó el traductorado de francés en la Alianza Francesa. Estudió Filosofía y Letras en la UBA, y realizó cursos de actuación. Su rol es de comentar y opinar, lo que hace con desenvoltura. Su presencia se nota en el programa ya que participa activamente y aporta puntos de vista diferentes a la mayoría. Tiene 49 años, es heterosexual y está casada.

Conni Ansaldi no es periodista, la definimos por la negativa porque no pudimos encontrar sus estudios sabemos que tiene secundario bilingüe. Se define como chimentera; que da que hablar por su ropa, sus escándalos o colores de pelo. Su participación en el programa como panelista es escasa, no siempre esta y cuando está presente habla poco. Sus opiniones o intervenciones son controversiales pero no siempre certeras. De estereotipo europeo, muy blanca, alta, pelirroja de pelo lacio, muy delgada y con pechos grandes permanece sentada con muy poco movimiento, de voz fuerte calculamos que tiene 30 años. Es heterosexual, tiene un hijo y está separada. 
Belen Franchese es actriz o vedette comienza como promotora en boliches bailables, participa en los concursos de tv y finalmente llega a ser panelista de este programa. Tiene alrededor de 30 años tienen pelo lacio y es rubia. De grandes pechos y formas exuberantes se exhibe de manera sensual. Su rol es de panelista pero rara vez participa. Siempre muy maquillada y vestida de manera ajustada permanece sentada en el sillón con cara atenta, habla en voz baja.

Paula Varela es una de las cronistas del programa, generalmente la vemos desde exteriores su rol es de comunicar a quienes están en el piso con el exterior. Ella hace las notas y las entrevistas donde siempre comunica con el piso. Es periodista y locutora, rubia de pelo lacio, delgada, amable de tono de voz medio. Es heterosexual y esta de novia. 
Ariès, P. (2011). El hombre ante la muerte. Buenos Aires: Aguilar, Altea, Taurus, Alfaguara.

Austin, J. (1955). Como hacer cosas con palabras. Edicion electronica de www.philosophia.cl/ Escuela de Filosofía Universidad ARCIS.

Badiner, É. (2003). Hombres Mujeres como salir del camino equivocada. Buenos Aires: Fondo de Cultura Economica de Argentina S.A.

Ballarino, F. (25 de septiembre de 2011). www.perfil.com. Recuperado el 13 de junio de 2012, de Perfil: http://www.perfil.com/ediciones/2011/9/edicion_612/contenidos/noticia_0069.html

Beauvoir De, S. (2007). El segundo sexo. Buenos Aires: De Bolsillo.

Beauvoir De, S. (1972). La mujer rota. Buenos Aires: Sudamericana.

Bonaparte, H. (2000). Unidos o dominados. Mujeres y varones frente al sistema patriarcal. Rosario: Homo Sapiens Ediciones.

Boria, Adriana y Morey, Patricia. (2010). Teoría social y género: Nancy Fraser y los dilemas teóricos contemporaneos. Buenos Aires : Catálogos.

Bourdieu, P. (2003). La dominación masculina. Barcelona: Anagrama.

Bourdieu, P. (1996). Sobre la televisión. Barcelona: Editorial Anagrama.

Butler, J. (X, № 19). Sujetos de sexo / género / deseo. Feminaria , 1-20.

Checa, S. (2008). Género, sexualidad y derechos reproductivos en la adolescencia. Buenos Aires:

Paidós. Tramas Sociales.

Danto, A. C. (2005). El abuso de la belleza, la estetica y el concepto de arte. Buenos Aires: Paidós.

Descartes. (2004). Meditaciones metafísicas. Buenos Aires: Ediciones Libertador.

Foucault, M. (1996). El orden del discurso. Madrid: Ediciones Endymión.

Foucault, M. (1976). Historia de la sexualidad. Tomo I. La volundad de saber. Mexico: Siglo XXI Editores.

Foucault, M. (2006). Historia de la sexualidad: 1- la voluntad del saber. Buenos Aires: Siglo Veintiuno Editores.

Giddens, A. (1998). La transformacion de la intimidad. Sexualidad, amor y erotismo en las sociedades modernas. Madrid: Ediciones Cátedra. 
Guzmán, F. (2010). La mirada secreta. Visiones y revisiones de lo femenino. Buenos Aires: Taurus, Alfaguara.

Héritier, F. (2007). Masculino/Femenino II. Disolver la jerarquia. Buenos Aires: Fondo de Cultura Económica.

http://odhpi.org/wp-content/uploads/2012/01/Informe-a-Anaya2011-sobre-Argentina.pdf. (2011). Informe Anaya.

Illouz, E. (2009). El consumo de la utopia romántica. El amor y las contradicciones culturales del capitalismo. Buenos Aires: Katz Editores.

Kohan, W. O. (2007). Infancia, política y pensamiento. Ensayos de filosofía y educación. Buenos Aires : Del estante.

Lacan, J. (1995). El seminario. Las sicosis 3. Paidos.

Lagunas, Cecilia; Bonaccorsi, Nélida; Romo Avilés, Nuria y Fernández Fraile, Maria Eugenia. (2009). Los estudios de las Mujeres de España y Argentina. Buenos Aires: Prometeo Libros.

Lamas, M. (1996). El género: la construcción cultural de la diferencia sexual. Mexico: Porrúa.

Le Breton, D. (2006). La sociologia del cuerpo. Buenos Aires: Nueva Vision.

Le Bretton, D. (2002). Antropologia del cuerpo y modernidad. Buenos Aires: Nueva vision.

Lévi Strauss, C. (1969). Las estructuras elementales del parentesco. Parte I. Buenos Aires: Paydós.

Liffschitz, G. (2003). Efectos Colaterales. Buenos Aires: Kapelusz.

Lomas, C. (2008). ¿El otoño del patriarcado? Luces y sombras de la igualdad entre mujeres y hombres. Barcelona: Ediciones Península.

Lomas, C. (2004). Los chicos también lloran. Identidades masculinas, igualdad entre los sexos y coeducacion. Barcelona: Paidós Educador.

Margulis, Mario; Urresti, Marcelo y Lewin Hugo. (2011). Las tramas del presente. Desde la perspectiva de la sociología de la cultura. Buenos Aires: Biblos. Sociedad.

Maurice, M. P. (2002). El mundo de la percepcion. Siete conferencias. Buenos Aires: Fondo de Cultura Económica.

Morgade, Graciela y Alonso, Graciela. (2008). Cuerpos y sexualidades en la escuela. De la normalidad a la disidencia. Buenos Aires: Paidós.

Navarro, Marisa y Stimpson, Catharine R. (2000). Cambios sociales, económicos y culturales. Buenos Aires: Fondo de Cultura Economica. 
Sartori, G. (8 de marzo de 2011). Homo videns.

Serre, M. (2011). Variaciones sobre el cuerpo. Buenos Aires: Fondo de Cultura Económica.

Sibilia, P. (2009). El hombre postorgánico. Cuerpo, subjetividad y tecnologías digitales. Buenos Aires: Fondo de Cultura Económica.

Simonnet, D. (2004). La más bella historia del amor. Buenos Aires: Fondo de Cultura Económica.

Vigarello, G. (2005). Historia de la belleza. El cuerpo y el arte de embellecer desde el Renacimiento hasta nuestros dias. Buenos Aires: Nueva Edicion.

Woolf, V. (2012). La muerte de la polilla y otros ensayos. Buenos Aires : La Bestia Equilatera. 